INSTITUTO DE PESQUISAS ENERGÉTICAS E NUCLEARES

Autarquia associada à Universidade de São Paulo

Estudo do processo para a aceleração da geração de amônia a partir de resíduos avícolas visando à produção de hidrogênio

\author{
Nayara dos Santos Egute
}

Dissertação apresentada como parte dos requisitos para obtenção do Grau de Mestre em Ciências na Área de Tecnologia Nuclear - Materias.

Orientadora:

Profa. Dra. Fátima Maria Sequeira de Carvalho

São Paulo 
Dedico este trabalho aos meus pais Tadakazu Egute - in memoriam e Sonia Maria dos Santos, os quais sempre estiveram comigo. 


\section{Agradecimentos}

Ao Instituto de Pesquisas Energéticas e Nucleares - IPEN, que em associação com a Universidade de São Paulo - USP, propiciou o ambiente para realização dessa dissertação.

À Comissão Nacional de Energia Nuclear - CNEN pela bolsa concedida.

Ao Centro de Célula a Combustível e Hidrogênio - CCCH pela acolhida.

À Faculdade de Medicina Veterinária e Zootecnia da Universidade de São Paulo - FMVZ - USP, nas pessoas do Prof. Dr. Cássio Xavier de Mendonça Junior e do senhor Abelardo, pelo fornecimento de material de trabalho.

À Granja Bom Jardim, na pessoa do senhor Nelson, pelo fornecimento de material de trabalho.

À Comissão de Pós-Graduação do IPEN pelo pronto atendimento oferecido nesses dois anos.

À Dra. Fátima Maria Sequeira de Carvalho pela orientação, pelo tratamento carinhoso com o qual sempre me distinguiu e por fornecer os instrumentos necessários para o desenvolvimento do projeto de pesquisa.

Ao Dr. Alcídio Abrão pela generosidade manifestada, desde o começo, sob a forma de idéias, incentivos e participação nessa dissertação.

Ao Prof. Dr. Afonso Rodrigues de Aquino pelas melhores aulas, pelas oportunidades de trabalho na área ambiental e pelos valiosos ensinamentos, sempre apresentados de forma paciente e coerente.

À Dra. Eliana Aricó, ao Dr. Jose Oscar Willian Vega Bustillos, ao Dr. Marcos Antonio Scapin pela contribuição na caracterização das amostras.

Ao Dr. Vanderlei Sérgio Bergamaschi e ao Dr. José Carlos Penteado pelos ensaios com o reformador de amônia.

Ao Jonny pelos contatos e pela visão empreendedora. 
Aos colegas e amigos que fizeram parte dessa jornada acadêmica: Rosely, Beatriz, Flávio, Jamil, Dionísio, Adriana, Ivan, Henrique, Pedro, Waldir, Sandra e Maria.

Aos amigos Kiki, Katatau, Rodrigo, Silvana e Dener de quem esta dissertação me afastou do convívio.

Ao Lé, Rose, Fernanda e ao Renan pelo amor incondicional.

À Tia Catia e ao Tio Marquinho pela confiança e ajuda em todas as situações e que, em determinados momentos, foram fundamentais.

Nunca vou me esquecer que, acima de tudo, esta foi uma conquista conjunta. 
Nunca ore suplicando cargas

mais leves, e sim ombros mais fortes

Phillips Brooks 


\title{
ESTUDO DO PROCESSO PARA A ACELERAÇÃO DA GERAÇÃO DE AMÔNIA A PARTIR DE RESÍDUOS AVÍCOLAS VISANDO À PRODUÇÃO DE HIDROGÊNIO
}

\author{
Nayara dos Santos Egute
}

\begin{abstract}
RESUMO
O hidrogênio, utilizado em células a combustível, pode ser produzido a partir de diferentes espécies químicas, entre elas a amônia. O gás amônia como matéria prima para produção de $\mathrm{H}_{2}$ tem sido utilizado devido ao seu alto conteúdo energético e de hidrogênio, pela sua facilidade de decomposição, grande disponibilidade, baixo custo, pelas baixas pressões de armazenamento e pelos subprodutos do processamento serem ambientalmente corretos. Uma das fontes de amônia são os sistemas produtivos de frango de corte e ovos. Nesses sistemas a amônia é gerada a partir da decomposição do ácido úrico encontrado na excreta das aves. O resíduo proveniente dos sistemas de frango de corte é a cama de frango e nos sistemas de produção de ovos é a excreta sem qualquer substrato. A caracterização desses resíduos foi realizada por meio das análises de Espectrometria de Fluorescência de Raios-X por Dispersão de Comprimento de Onda (WDXRF), Análise Elementar CHN, Termogravimetria e Cromatografia a gás acoplada à Espectrometria de massa GC/MS. Os fatores estudados e que influenciam a volatilização da amônia foram: teor de nitrogênio, tempo de criação, enzima urease, temperatura, $\mathrm{pH}$ e teor de umidade. Os resultados dos experimentos com a cama de frango e com a excreta permitem concluir que a manipulação dos seguintes parâmetros aumentaram a emissão de amônia: o pH, o teor de nitrogênio, o tempo de criação, idade das aves e acúmulo de excreta, enzima urease e a temperatura. A adição de diferentes quantidades de areia na excreta e de volumes de água na cama de frango inibiram a emissão de amônia. A variação da quantidade de material (cama ou excreta) e do volume do frasco utilizado como câmara incubadora não demonstraram alterações significativas para serem escolhidos como uma variável. Na comparação da cama de frango com a excreta, a excreta foi considerada mais adequada aos objetivos do trabalho, pois a concentração de amônia determinada nos experimentos foi maior nesse material. Devido à grande quantidade de cama de frango e de excretas resultantes dos processos de produção, o reaproveitamento dos resíduos avícolas para a obtenção de amônia se faz necessário para melhorar a qualidade do meio ambiente local. A possibilidade do aumento da emissão de amônia, verificada nesse trabalho, e a sua utilização em um sistema geração de amônia - produção de hidrogênio - célula a combustível, poderá produzir eletricidade no próprio empreendimento, reduzindo os gastos das granjas e destinando adequadamente esses resíduos.
\end{abstract}




\title{
STUDY OF THE ACCELERATION OF AMMONIA GENERATION PROCESS FROM POULTRY RESIDUES AIMING AT HYDROGEN PRODUCTION
}

\author{
Nayara dos Santos Egute
}

\begin{abstract}
The hydrogen, utilized in fuel cells, can be produced from a variety of intermediate chemicals, between them, the ammonia. The ammonia gas as a raw material for the hydrogen production has been used due to its high energetic content, facility of decomposition, high availability, low prices, low storage pressure and its by-products are environmentally correct. One of the sources of ammonia is poultry and egg production systems. In these systems the ammonia is produced from the decomposition of uric acid present in the excreta of birds. The residue from the poultry-rearing farms is the broiler litter and from the egg production system is the excreta without any substrate. The characterization of these residues was performed using the Wavelength-Dispersive X-Ray Fluorescence (WDXRF), Elementary Analysis (CHN), Termogravimetry and GC/MS - Gas chromatography/ Mass spectrometry. The studied factors which influence the ammonia volatilization were: nitrogen content, raising period, urease enzyme, temperature, $\mathrm{pH}$ and moisture content. The experiment results with poultry litter and excreta allow to conclude that the manipulation of the following parameters increased the ammonia emission: $\mathrm{pH}$, nitrogen content, raising period, age of birds and excreta accumulation, urease enzyme and the temperature. The addition of different amounts of sand in the excreta and different volumes of water in the poultry litter inhibited the emission of ammonia. The variation of the quantity of material (broiler litter or excreta) and the volume of the flask used as incubator chamber showed no significant alterations to be chosen as a variable. The excreta was considered more appropriate than poultry litter for the objectives of this work due to the higher ammonia concentrations determined in this material. Due to the large amount of poultry litter and excreta from the production processes, the reuse of poultry residues to obtain ammonia is necessary to improve the quality of the local environment. The possibility of ammonia emission increment observed in this study, and its use in a system of ammonia generation - hydrogen production - fuel cell might produce electricity in the enterprise, reducing the expenses of the farms and providing a properly destination for these residues.
\end{abstract}


Página

1 INTRODUÇÃO ……………………………………………………………………….... 1

2 OBJETIVOS

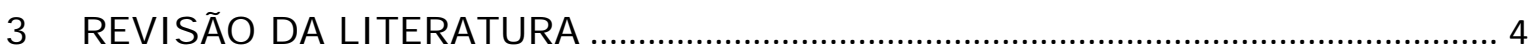

3.1 Energia e Impactos Ambientais .......................................................................... 4

3.2 Células a Combustível .......................................................................................... 6

3.3 Hidrogênio ……………………………………………………………….... 13

3.3.1 Produção de Hidrogênio a partir da biomassa ........................................ 15

3.3.2 Purificação do Hidrogênio .......................................................................... 17

3.3.3 Manipulação do Hidrogênio ........................................................................ 18

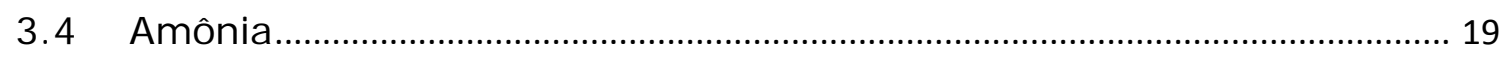

3.4.1 Amônia e hidrogênio ................................................................................... 21

3.4.2 Sistema de armazenamento de amônia ........................................................ 22

3.4.3 Obtenção de hidrogênio por decomposição da amônia ........................ 23

3.5 Sistemas Produtivos de Frango de Corte e Ovos ........................................... 25

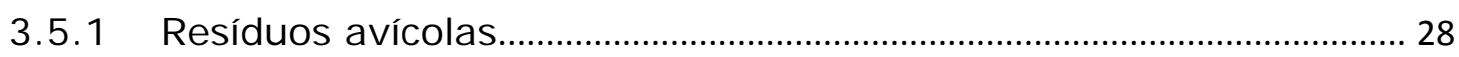

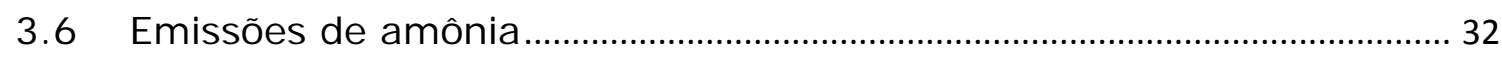

3.6.1 Estimativa da taxa de emissão de amônia ................................................ 33

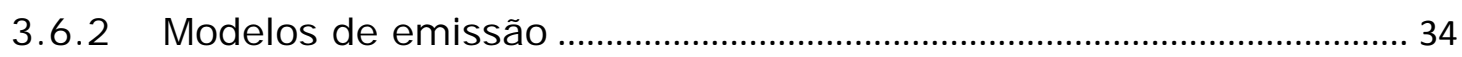

3.7 Fatores que influenciam a emissão de amônia................................................ 40

3.8 Danos Provocados pela amônia ……………………………………………..... 48

3.9 Custos associados à amônia …………………………………………………..... 50

3.10 Matéria orgânica e energia ............................................................................ 52

4 MATERIAIS E MÉTODOS ………………………………………………………….... 55

4.1 Caracterização das amostras ............................................................................. 55 
4.1.1 Espectrometria de Fluorescência de Raios-X por Dispersão de Comprimento de Onda (WDXRF) .......................................................................... 56

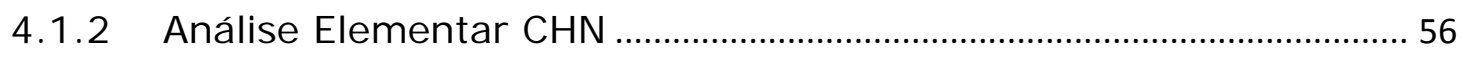

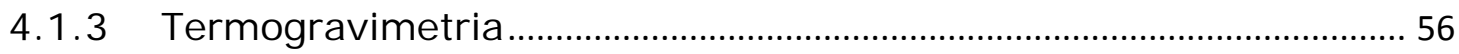

4.1.4 Cromatografia a gás acoplada à Espectrometria de massa GC/MS57

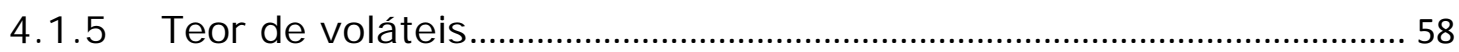

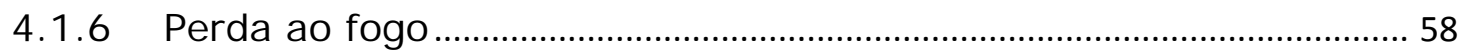

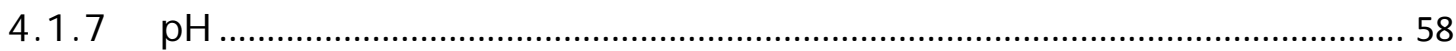

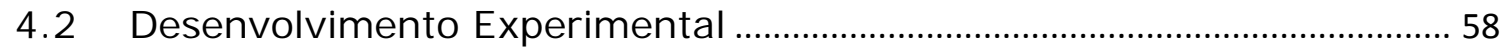

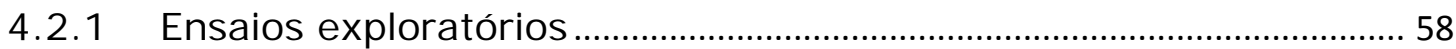

4.3 Estudo dos fatores que influenciam a volatilização da amônia ................ 59

4.3.1 Experimentos com a cama de frango .......................................................5 59

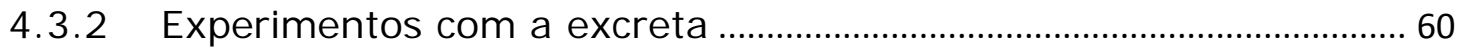

4.3.3 Investigação da ação da enzima urease do feijão-de-porco .............6 63

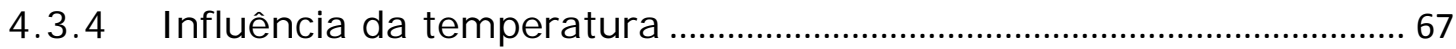

4.3.5 Influência da temperatura e do pH - concentração de carbonato de

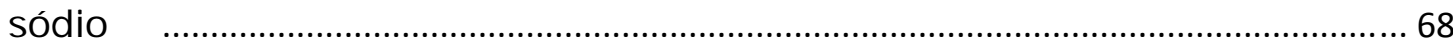

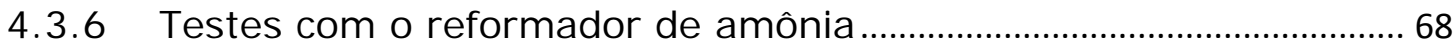

5 RESULTADOS E DISCUSSÃO

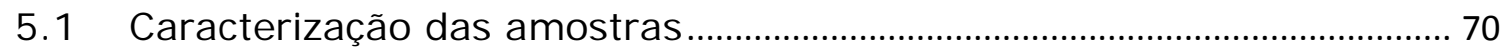

5.1.1 Fluorescência de Raios-X....................................................................... 70

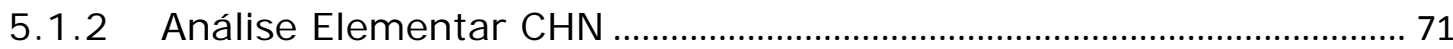

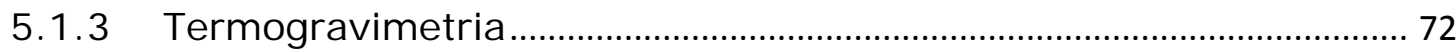

5.1.4 Cromatografia a Gás acoplada à Espectrometria de Massa GC/MS78

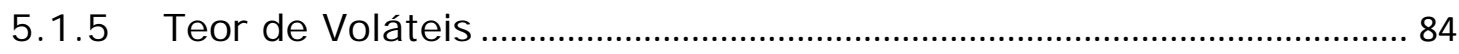

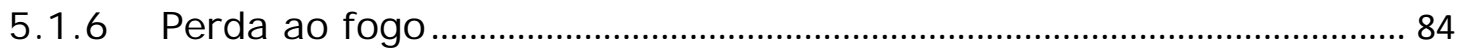

5.2 Estudo dos fatores que influenciam a volatilização da amônia ................ 85

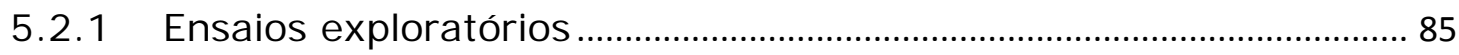


5.2.2 Experimentos com a cama de frango ................................................... 85

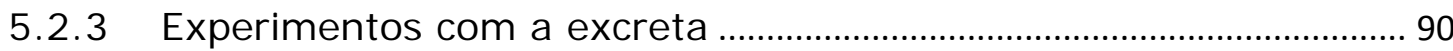

5.2.4 Influência da ação da enzima urease do feijão-de-porco................... 96

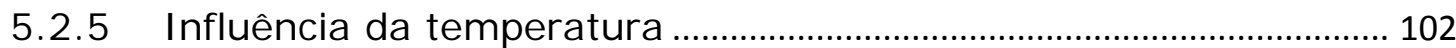

5.2.6 Influência da temperatura e do pH - concentração de carbonato de

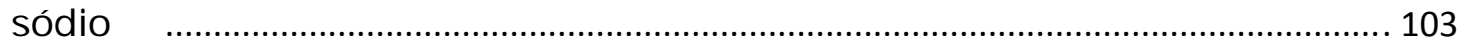

5.3 Testes com o reformador de amônia ................................................................. 104

6 CONCLUSÕES

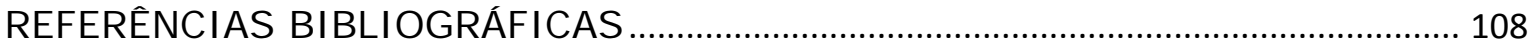




\section{LISTA DE TABELAS}

Página

TABELA 1 - Tipos de células a combustível 12

TABELA 2 - Produção de frangos e de ovos no Brasil no primeiro trimestre de 2010

TABELA 3 - Vantagens e desvantagens de materiais usados como cama nas granjas avícolas

TABELA 4 - Estimativa das fontes e sorvedouros da amônia atmosférica 33

TABELA 5 - Tipos, ambientes, fontes de alimento e subprodutos do crescimento dos microorganismos

TABELA 6 - Níveis máximos de gases para sistemas produtivos de frangos.... 49

TABELA 7 - Custo estimado associado às condições inadequadas da cama para 20.000 aves.

TABELA 8 - Resultados da análise semi-quantitativa da cama de frango e da excreta realizada usando a técnica de Fluorescência de Raios- $X$.

TABELA 9 - Média dos resultados da análise elementar por CHN das amostras de cama de frango e excreta

TABELA 10 - Dados da decomposição térmica das amostras de cama de frango e excreta.

TABELA 11 - Teores de voláteis e de cinzas das amostras de cama de frango e excreta

TABELA 12 - Características dos compostos identificados por GC/MS da amostra da cama de frango úmida

TABELA 13 - Características dos compostos identificados por GC/MS da amostra da cama de frango sem umidade 80

TABELA 14 - Características dos compostos identificados por GC/MS da amostra da excreta úmida

TABELA 15 - Características dos compostos identificados por GC/MS da amostra da excreta sem umidade

TABELA 16 - Composição percentual dos ácidos graxos presentes na gordura de galinhas domésticas

TABELA 17 - Teores de voláteis da cama de frango e da excreta 84 
TABELA 18 - Valores de perda ao fogo da cama de frango e da excreta 84

TABELA 19 - Valores de pH da cama de frango incubada nos frascos com diferentes concentrações de carbonato de sódio.

TABELA 20 - Frascos com diferentes volumes e concentração de amônia fixada durante 13 dias.

TABELA 21 - Relação entre as diferentes quantidades de cama de frango e as concentrações de amônia fixadas durante 19 dias

TABELA 22 - Volume de água adicionado à $100 \mathrm{~g}$ de cama de frango e concentração de amônia fixada durante 19 dias

TABELA 23 - Valores de pH da excreta incubada nos frascos com diferentes concentrações de carbonato de sódio

TABELA 24 - Frascos com diferentes volumes e concentração de amônia fixada durante 24, 48 e 72 horas de incubação

TABELA 25 - Diferentes quantidades de excreta em relação à concentração de amônia fixada durante 24, 48 e 72 horas de incubação..... 93

TABELA 26 - Diferentes tempos de acúmulo de excreta e concentração de amônia fixada durante 24, 48 e 72 horas de incubação.....

TABELA 27 - Diferentes quantidades de areia adicionada a $100 \mathrm{~g}$ de excreta e concentração de amônia fixada durante 7 dias de incubação

TABELA 28 - Comparação entre os diferentes tipos de ração (com diferentes teores de nitrogênio) e concentração de amônia fixada durante 8 dias de incubação.

TABELA 29 - Concentração de amônia fixada proveniente da solução de uréia com o extrato de feijão-de-porco

TABELA 30 - Diferentes volumes de extrato de feijão-de-porco (segunda metodologia) e concentração de amônia fixada.

TABELA 31 - Comparação entre as diferentes metodologias empregadas para a extração da enzima urease do feijão-de-porco 100

TABELA 32 - Quantidade de feijão-de-porco triturado e concentração de amônia fixada 101

TABELA 33 - Temperatura em que o frasco teste foi incubado, concentração de carbonato de sódio e concentração de amônia fixada em 24 horas. 


\section{LISTA DE FIGURAS}

Página

FIGURA 1 - Diagrama de fluxo para a produção de energia utilizando a amônia como combustível

FIGURA 2 - Sistema automatizado de produção de poedeiras em gaiolas, no qual as excretas são transportadas por esteiras

FIGURA 3 - Imagem de frangos criados sobre o material utilizado como piso (cama de frango)

FIGURA 4 - Ilustração dos processos relacionados com as emissões de amônia da cama de frango

FIGURA 5 - I magem de um sistema produtivo de frango de corte 48

FIGURA 6 - Efeito da atmosfera da amônia na massa corpórea de frangos durante sete semanas

FIGURA 7 - Fluxo de energia em uma operação de criação animal no qual as setas brancas denotam a transferência de energia

FIGURA 8 - Primeira metodologia (a) e segunda metodologia (b) para a extração da enzima urease

FIGURA 9 - Aumento de tamanho do feijão-de-porco, triturado (a) e grão (b), devido à absorção de água

FIGURA 10 - Grão de feijão-de-porco da esquerda em tamanho normal e grão de feijão-de-porco da direita após 24 horas em água destilada

FIGURA 11 - Filtragem a vácuo do feijão-de-porco triturado para a retirada do extrato contendo a enzima urease 66

FIGURA 12 - Cama de frango - curva termogravimétrica (TG) e curva termogravimétrica derivada (DTG)

FIGURA 13 - Excreta - curva termogravimétrica (TG) e curva

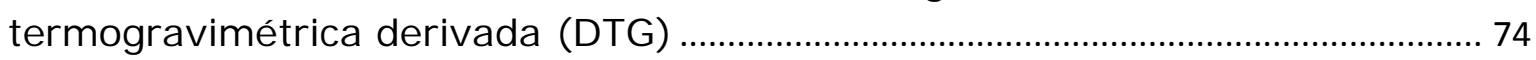

FIGURA 14 - Curva termogravimétrica e gases envolvidos na decomposição da cama de frango 75

FIGURA 15 - Cama de frango - Análise Térmica Diferencial DTA 77

FIGURA 16 - Excreta - Análise Térmica Diferencial DTA 77

FIGURA 17 - Cromatograma GC/MS da cama de frango úmida 79 
FIGURA 18 - Cromatograma GC/MS da cama de frango sem umidade. 80

FIGURA 19 - Cromatograma GC/MS da excreta úmida.

FIGURA 20 - Cromatograma GC/MS da excreta sem umidade 82

FIGURA 21 - Concentrações de carbonato de sódio e concentração de amônia fixada durante 24 horas de incubação. 86

FIGURA 22 - Segunda faixa de concentração de carbonato de sódio e concentração de amônia fixada em 24 horas e em 12 dias de incubação.....

FIGURA 23 - Concentrações de carbonato de sódio e concentração de amônia fixada durante 24,48 e 72 horas de incubação.

FIGURA 24 - Tubos de ensaio contendo extrato de feijão-de-porco (a); solução de uréia (b); extrato de feijão-de-porco + solução de uréia (c) e seus respectivos valores de $\mathrm{pH}$.

FIGURA 25 - Tubo de ensaio contendo extrato de feijão-de-porco e solução de uréia. A coloração rosa adquirida após a adição de fenolftaleína indica o caráter básico da solução. 98

FIGURA 26 - Volume de extrato de feijão-de-porco (primeira metodologia) adicionado a $100 \mathrm{~g}$ de excreta e concentração de amônia fixada durante 7 dias de incubação 99

FIGURA 27 - Concentração de amônia fixada durante 24 horas em diferentes temperaturas de incubação 102

FIGURA 28 - Cromatogramas das análises do gás de reforma do hidróxido de amônio 


\section{INTRODUÇÃO}

Assegurar o suprimento de energia com a devida proteção ao meio ambiente é um dos desafios atuais [1]. Desde a primeira crise do petróleo em 1973, a perspectiva mundial de energia tem mudado. Muitas nações ricas vêm tentando reduzir sua dependência deste insumo, diversificando suas fontes de energia primária. Mais significante, todavia, tem sido a tendência no aumento de uma consciência ambiental [2].

As células a combustível são sistemas eletroquímicos capazes de transformar a energia química de um combustível diretamente em energia elétrica e calor. Esta conversão ocorre por meio de reações eletroquímicas em dois eletrodos separados por um eletrólito apropriado, ou seja, a oxidação de um combustível no ânodo e a redução de um oxidante no cátodo. Escolhendo-se, por exemplo, hidrogênio como combustível e oxigênio como oxidante tem-se, na denominada célula ácida, a formação de água e a produção de calor, além da liberação de elétrons livres, que podem gerar trabalho elétrico. A água é formada pelos prótons produzidos na reação anódica, que são conduzidos pelo eletrólito até o cátodo, onde se ligam ao oxigênio e aos elétrons [3].

Neste início do século XXI, o hidrogênio tem sido considerado como a grande oportunidade de geração de energia com baixo impacto ambiental. Não existem fontes naturais desta substância e, por conseqüência, não se apresenta como um combustível primário.

O hidrogênio pode ser produzido a partir de diferentes fontes, divididas em três classes principais: combustíveis fósseis, fontes renováveis e eletrólise da água. Entre as fontes renováveis, tem-se dado destaque à biomassa, que envolve também materiais em decomposição [1].

Os desafios para a economia do hidrogênio são a sua produção e armazenagem de maneira conveniente, eficiente e segura.

A amônia apresenta características para ser considerada um ótimo armazenador de hidrogênio [4], pois sua decomposição ocorre em um único passo reacional [5] e não há monóxido de carbono no gás produzido [6]. 
Como exemplos de fontes emissoras de amônia podemos citar os sistemas produtivos de frango de corte e a cadeia produtiva de ovos.

A cadeia produtiva de ovos no Brasil se caracteriza pela produção de ovos para consumo tanto "in natura", quanto industrializados. A produção é feita predominantemente no sistema de criação em gaiolas, com as granjas de cria e recria separadas das granjas de produção. A ave não tem contato direto com as excretas e essas não são misturadas a qualquer substrato. A maioria das granjas é composta por produtores independentes de pequeno e médio porte, que preparam a própria ração na propriedade e trabalham com os tradicionais galpões abertos. Existe, por outro lado, grandes produtores que estão partindo para a adequação climática e automação das instalações [7].

A produção de frangos de corte é a forma mais eficiente e barata de se produzir proteína animal para alimentação humana no mundo. Em curto tempo os frangos se tornaram os animais mais eficientes para transformar grãos em proteína animal, com utilização de pouco espaço, pouca água e energia e, adicionalmente, é possível o aproveitamento do animal inteiro após o abate [8].

A amônia, nesses sistemas produtivos, é gerada pela decomposição química e microbiana do ácido úrico após a excreção pela ave [9]. Quando as excretas do frango se juntam ao material utilizado como piso ocorre uma rápida multiplicação microbiana [10]. O crescente aumento na criação de frangos naturalmente provoca maior geração de resíduos e, conseqüentemente, aumenta as emissões de amônia ao meio ambiente.

Muitos fatores influenciam na volatilização da amônia proveniente da excreta das aves. $O$ estudo desses fatores e a manipulação dos parâmetros que incrementam essa geração, a reforma catalítica e a obtenção de hidrogênio para o uso em células a combustível podem contribuir para a solução de questões técnicas e ambientais. Os resíduos avícolas podem ser destinados adequadamente e a obtenção de hidrogênio a partir deles poderá contribuir para o setor energético. 


\section{OBJETIVOS}

O objetivo deste trabalho é investigar as condições que propiciam um maior rendimento na formação da amônia proveniente dos resíduos dos sistemas produtivos de frango de corte e das granjas produtoras de ovos. O processo possibilitará a obtenção de amônia em laboratório, por meio da manipulação dos parâmetros que influenciam sua emissão. O gás gerado pode ser submetido a um processo de reforma visando à obtenção de hidrogênio para uso em células a combustível. 


\section{REVISÃO DA LITERATURA}

\subsection{Energia e Impactos Ambientais}

Tecnologias de energia, particularmente aquelas relacionadas com a extração de combustíveis fósseis, transporte, processo e produto final (que quase sempre é a combustão) têm impactos prejudiciais ao meio ambiente, causando efeitos adversos diretos $\mathrm{e}$ indiretos na economia global. Esses impactos ambientais podem ser locais, como a poluição atmosférica causada pelas emissões gasosas, ou da água e do solo devido a derramamentos e vazamentos de produtos perigosos. Os impactos ambientais regionais são devidos à dispersão de poluentes e chuvas ácidas e os globais são resultados da acumulação, na atmosfera, de gases responsáveis pelo efeito estufa com conseqüências danosas como o aquecimento global, mudanças climáticas e o aumento do nível dos oceanos [2].

Segundo definição do IPCC - Painel Internacional de Mudanças Climáticas [11], os gases responsáveis pelo efeito estufa são aqueles que na atmosfera absorvem radiação eletromagnética, em comprimentos de ondas específicos (região do infravermelho), emitida pela superfície terrestre e pelas nuvens. Os gases, por sua vez, emitem radiação infravermelha de um nível onde as temperaturas são mais frias do que as da superfície. O efeito resultante é a retenção local de parte da energia absorvida e a tendência a aquecer a superfície planetária. Vapor de água $\left(\mathrm{H}_{2} \mathrm{O}\right)$, dióxido de carbono $\left(\mathrm{CO}_{2}\right)$, óxido de nitrogênio $\left(\mathrm{N}_{2} \mathrm{O}\right)$, metano $\left(\mathrm{CH}_{4}\right)$ e ozônio $\left(\mathrm{O}_{3}\right)$ são os principais gases responsáveis pelo efeito estufa na atmosfera terrestre.

O efeito estufa é um mecanismo natural da Terra, importante para a manutenção da vida, porém a alta concentração dos gases emitidos intensifica esse efeito.

A EPA - Agência de Proteção Ambiental dos Estados Unidos [12] publica um relatório com indicadores da mudança climática, a qual já está bem documentada e com evidências sobre o aumento da temperatura média do planeta. As conseqüências da retenção da energia do sol pelos gases do efeito estufa são o aumento da temperatura do ar e dos oceanos, derretimento de neve e geleiras, aumento do nível do mar entre outras. 
Os combustíveis fósseis (petróleo, carvão e gás natural), após a sua queima para a obtenção de energia, são os grandes emissores dos gases responsáveis pelo efeito estufa. Assim, devido aos impactos causados e ao fato das fontes de combustíveis fósseis serem limitadas, é cada vez mais importante a busca por fontes alternativas de energia que sejam sustentáveis.

Segundo os resultados preliminares do Balanço Energético Nacional 2010, ano base 2009 [13] a produção de eletricidade, em 2009, obteve um ligeiro acréscimo de $0,6 \%$ com relação a 2008 . Observou-se uma forte queda de $30,6 \%$ na geração através de fontes não renováveis, em relação ao ano anterior, com destaque para o gás natural $(-53,7 \%)$ e derivados de petróleo $(-17,1 \%)$.

Já a geração por meio de fontes renováveis apresentou aumento de 5,5\%, sendo que a hidráulica foi uma das que mais cresceram. Com a maior utilização das usinas hidrelétricas, em detrimento às termelétricas, a eletricidade de origem renovável aumentou de $85,1 \%$, em 2008, para $89,8 \%$ no último ano [13].

Devido ao menor consumo de energia proveniente de combustíveis fósseis em relação ao ano anterior, é natural que as emissões de $\mathrm{CO}_{2}$ também fossem menores. Mas cabe destacar que, como resultado do aumento da utilização de energias renováveis, enquanto a oferta interna de energia caiu 3,4\%, as emissões totais de $\mathrm{CO}_{2}$ diminuíram $6,2 \%$ em relação a 2008. Na geração de eletricidade neste mesmo período, mesmo com um aumento de $0,6 \%$, registrou-se uma queda de $33,5 \%$ nas emissões [13].

No setor agropecuário as principais fontes de energia são o óleo diesel $(57,8 \%)$, a lenha $(25,3 \%)$ e outras fontes que incluem gás natural, óleo combustível e eletricidade $(17,0 \%)$ [13]. No meio rural as pequenas oscilações de custo e preço podem reduzir drasticamente a competitividade. Assim esse fator, aliado à crise de energia, tem determinado a procura dos empreendedores dos setores da agropecuária por alternativas energéticas mais atraentes [14].

A demanda por energia é derivada da necessidade de se realizar atividades produtivas ou de lazer na sociedade [15]. O consumo de energia está ligado ao desenvolvimento da região, quanto maior o consumo de energia mais 
desenvolvida é a região. O fornecimento de energia a comunidades isoladas ainda é um sério problema em nosso país.

O Programa Luz para todos, do Ministério de Minas e Energia [16], tem por objetivo acabar com a exclusão elétrica no país por meio do uso dos recursos locais disponíveis. Além da Amazônia, citada neste Programa, outras áreas não têm acesso à energia, o que influi na qualidade de vida da população.

Uma das alternativas energéticas, que pode atender a alguns dos requisitos técnicos e ambientais abordados acima são as células a combustível.

\subsection{Células a Combustível}

A célula a combustível foi desenvolvida a partir da descoberta que Willian Robert Grove fez, em 1839, de que a combinação de hidrogênio e oxigênio resulta em água e corrente elétrica. O termo "célula a combustível" foi cunhado em 1889 por Ludwig Mond e Charles Langer que tentaram construir, sem sucesso, o primeiro dispositivo prático, usando ar e gás industrial gerado do carvão. Outras tentativas, no início do século XX, para a construção de células a combustível que pudessem converter carvão ou carbono em eletricidade também falharam, em função da falta de conhecimento da cinética da reação, dos materiais de construção e de eletrodos apropriados [17].

Os primeiros experimentos bem sucedidos foram resultados do trabalho, em 1932, do engenheiro Francis Bacon. Ele aperfeiçoou os caríssimos catalisadores constituídos de platina, usados por Mond e Langer, em uma célula hidrogênio-oxigênio, usando um eletrólito alcalino menos corrosivo e eletrodos de níquel mais baratos. Os desafios técnicos eram muitos e foi somente no ano de 1959 que Bacon conseguiu construir um protótipo de 5kW, capaz de alimentar uma máquina de solda. Em outubro desse mesmo ano, Harry Ihrig, da AllisChalmers Manufacturing Company, demonstrou seu famoso trator de 20 HP acionado a célula a combustível [17].

No entanto, somente com a Agência Espacial dos EUA, a NASA, a célula a combustível teve o uso regular estudado para ser utilizada nos programas Gemini e Appolo. Tudo o que a NASA precisava era de um equipamento que gerasse 
energia com eficiência consumindo um combustível leve e com grande densidade de energia - o hidrogênio [18].

A célula a combustível é uma tecnologia que utiliza a combinação química entre os gases oxigênio $\left(\mathrm{O}_{2}\right)$ e hidrogênio $\left(\mathrm{H}_{2}\right)$ para gerar energia elétrica, energia térmica (calor) e água [18]. Uma unidade de célula combustível próximo ao ideal forneceria uma tensão de aproximadamente 1,16 volts. Porém, como a eficiência é sempre menor do que $100 \%$, a tensão fornecida é menor. Visto que a maior parte das aplicações necessita de valores de tensão maiores do que esta, a tensão requerida pode ser obtida através da conexão em série de várias células a combustível individuais, formando o que se denomina de "pilha de células a combustível" ou, em inglês, "stack" (fuel cell stack) [18].

Os componentes de uma célula unitária são [3]:

- Ânodo - eletrodo do combustível, onde ocorre a oxidação do combustível. $O$ ânodo fornece a interface entre os combustíveis e o eletrólito; catalisa a reação de oxidação e conduz os elétrons para o circuito externo;

- Cátodo - eletrodo do oxidante, onde ocorre a redução do oxidante. $O$ cátodo fornece a interface entre o oxigênio e o eletrólito; catalisa a reação de redução e conduz os elétrons do circuito externo até o sítio reativo;

- Eletrólito - transporta as espécies iônicas envolvidas nas reações eletródicas, entre os eletrodos; previne a condução eletrônica (curto circuito entre os eletrodos) e possui a função de separar os gases dos eletrodos, mesmo a pressões elevadas. Geralmente, o eletrólito dá nome a um tipo de célula a combustível;

- Camada difusora - sem catalisador. Esta camada vem sempre associada aos eletrodos, ânodo e cátodo. Possui as funções de distribuição dos gases reagentes na camada catalítica e o contato elétrico do eletrodo com a placa bipolar. A camada difusora é conhecida também pela sigla GDL (gas diffusion layer). 
No caso de módulos (empilhamentos, stack), incluem-se ainda:

- Placas bipolares ou interconectores - ligam, em série, o ânodo de uma célula ao cátodo de outra. Este componente deve ser denso e resistente às duas atmosferas (redutora e oxidante), além de um bom condutor eletrônico;

- Outros - sistema operacional (no caso de módulos); sistema de processamento de combustível (no caso, reforma); vedações; trocadores de calor e inversor, etc [3].

Existem pelo menos seis tecnologias de células a combustível para combinarem hidrogênio e oxigênio, mas elas têm basicamente o mesmo princípio de funcionamento. Resumidamente, de um lado da célula entra o hidrogênio e do outro entra o oxigênio. No meio, entre os eletrodos, existem o eletrólito e o catalisador, que são a lógica de todo o funcionamento da célula a combustível [18].

O funcionamento passo a passo está descrito a seguir [18]:

1. De um lado da célula a combustível, o gás hidrogênio $\left(\mathrm{H}_{2}\right)$ pressurizado é bombeado para o terminal negativo do eletrodo, o ânodo. $O$ gás é forçado a passar por canais de fluxo até atingir o catalisador.

2. Quando a molécula de hidrogênio entra em contato com o catalisador, ele se separa em dois íons de hidrogênio $\left(\mathrm{H}^{+}\right)$e dois elétrons $\left(\mathrm{e}^{-}\right)$.

3. Os elétrons (e-) são conduzidos através do eletrodo até atingirem o circuito externo, onde temos um fluxo de elétrons - a corrente elétrica no sentido do eletrodo positivo, o cátodo. A corrente elétrica que flui pelo circuito externo gera eletricidade. As moléculas do gás hidrogênio $\left(\mathrm{H}_{2}\right)$ que não foram quebradas pelos catalisadores não passam através do eletrólito, mas são realimentados até que este processo ocorra. A equação 1 representa a reação química deste passo.

$$
2 \mathrm{H}_{2(\mathrm{~g})} \longrightarrow 4 \mathrm{H}^{+}{ }_{(\mathrm{aq})}+4 \mathrm{e}^{-}
$$


4. Do outro lado da célula a combustível o gás oxigênio $\left(\mathrm{O}_{2}\right)$, ou ar, é bombeado para o terminal positivo do eletrodo, o cátodo. $\mathrm{O}$ gás é forçado a passar por canais de fluxo até atingir o catalisador.

5. Uma vez no catalisador, a molécula de oxigênio combina-se com os íons $\mathrm{H}^{+}$que atravessam o eletrólito e com os elétrons, para formar a molécula de água $\left(\mathrm{H}_{2} \mathrm{O}\right)$. Nesta reação, certa quantidade de calor é liberada (vapor de água) [18]. A equação 2 representa a reação química deste passo.

$$
\mathrm{O}_{2(\mathrm{~g})}+4 \mathrm{H}^{+}{ }_{(\mathrm{qq})}+4 \mathrm{e}^{-} \rightarrow 2 \mathrm{H}_{2} \mathrm{O}_{(\mathrm{g})}
$$

As células a combustível são classificadas segundo o tipo de eletrólito que utilizam e, conseqüentemente, por sua temperatura de operação. Destacam-se dois grupos principais de células: as de baixa temperatura de operação - AFC (alkaline fuel cell); PEMFC (proton exchange membrane fuel cell); DMFC (direct methanol fuel cell) e PAFC (phosphoric acid fuel cell) e as de alta temperatura de operação - MCFC (molten carbonate fuel) e SOFC (solid oxide fuel cell) [19].

\section{$\underline{\text { AFC - Célula a Combustível Alcalina }}$}

Baseia-se na utilização de um eletrólito alcalino, geralmente $\mathrm{KOH}$ em concentrações de 3 a $45 \%$. O íon trocado no eletrólito é, então, o $\mathrm{OH}^{-}$. Opera na faixa de temperatura de 60 a $90^{\circ} \mathrm{C}$ e em pressões que variam de 1 a $4 \mathrm{~atm}$. Devido ao caráter alcalino do meio reacional permite o uso de combustíveis líquidos como a hidrazina $\left(\mathrm{N}_{2} \mathrm{H}_{4}\right)$ ou amônia $\left(\mathrm{NH}_{3}\right)$. É a mais eficiente das células a combustível devido à cinética da reação de redução de oxigênio favorecida em meio alcalino. Uma das desvantagens da AFC é sua sensibilidade para o dióxido de carbono [3].

\section{PEMFC - Célula a Combustível de Membrana Polimérica Condutora de Prótons}

A célula do tipo PEMFC utiliza o Nafion ${ }^{\circledast}$ como membrana e opera na faixa de temperatura de aproximadamente de 60 a $90^{\circ} \mathrm{C}$. As vantagens deste tipo de célula são: maiores densidades de potência do que os outros tipos de células a combustível; menor relação massa/volume; eletrólito sólido hidratado (pseudo- 
sólido); fácil liga/desliga e são robustas. As principais desvantagens são: custo, sensibilidade ao $\mathrm{CO}$ e necessidade de gerenciamento de água da membrana [3].

\section{DMFC - Célula a Combustível de Metanol Direto}

$\mathrm{Na}$ célula do tipo DMFC o combustível utilizado é o metanol que sofre oxidação anódica direta. $\mathrm{O}$ metanol pode ser alimentado na forma líquida ou vaporizado, diluído com $\mathrm{H}_{2} \mathrm{O}$ e $\mathrm{N}_{2}$. Também pertence à classe de células a combustível de baixa temperatura, operando na mesma faixa das descritas acima. Uma vantagem das células a álcool direto é a possibilidade de usar um combustível na forma líquida, facilitando o seu gerenciamento no sistema. No caso do metanol as desvantagens são a sua toxicidade e a sua obtenção de fontes fósseis. O etanol apresenta a vantagem de ser obtido de biomassa, portanto renovável, e ser menos tóxico, porém a oxidação completa da molécula de etanol necessita de energia extra para a ruptura da ligação C-C [3].

\section{PAFC - Célula a Combustível de Ácido Fosfórico}

A célula PAFC é baseada no uso de ácido fosfórico como eletrólito. Os eletrólitos ácidos são preferidos devido a não sensibilidade ao $\mathrm{CO}_{2 \text {. }}$ A estabilidade do ácido fosfórico é alta comparada a outros ácido comuns e conseqüentemente, a PAFC é capaz de operar em temperaturas elevadas, em torno de $200^{\circ} \mathrm{C}$ [19]. A célula de ácido fosfórico pode ser usada em conjunção com uma variedade de combustíveis como, por exemplo, os hidrocarbonetos leves e mais limpos como o gás natural, nafta ou metanol utilizando-se o processo de reforma apropriado. A maior temperatura de operação confere maior tolerância ao CO (até $1 \%$ ), porém mesmo com essa temperatura há a necessidade de eletrocatalisadores de metais nobres $(\mathrm{Pt})[3]$.

\section{MCFC - Célula a Combustível de Carbonato Fundido}

Estas células caracterizam-se pela utilização de eletrólitos formados de uma mistura, ou uma solução, de carbonatos fundidos de metais alcalinos, por exemplo, carbonato de lítio $\left(\mathrm{Li}_{2} \mathrm{CO}_{3}\right)$, carbonato de sódio $\left(\mathrm{Na}_{2} \mathrm{CO}_{3}\right)$, carbonato de potássio $\left(\mathrm{K}_{2} \mathrm{CO}_{3}\right)$, etc. em uma matriz suporte de aluminato de lítio $\left(\mathrm{LiAlO}_{2}\right)$. Este tipo de célula pertence à classe de célula a combustível de alta temperatura de operação, pois funciona a, aproximadamente, $600^{\circ} \mathrm{C}$. Por este motivo, é própria 
para aplicações estacionárias de geração de energia elétrica e calor (co-geração) [19]. Estas células podem operar com uma variedade de combustíveis, como: hidrogênio, gás natural, propano, gás de aterro sanitário, diesel e produtos da gaseificação do carvão [3].

\section{$\underline{\text { SOFC - Célula a Combustível de Óxido Sólido }}$}

As células SOFC fazem uso de uma propriedade importante da zircônia estabilizada com ítria (YSZ - ytria stabilized zirconia). A YSZ, com aproximadamente $8 \% \mathrm{em}$ mol de ítria, que estabiliza a fase cúbica da zircônia, passa a ser condutora de íons oxigênio $\left(\mathrm{O}^{2-}\right)$, a partir de $800^{\circ} \mathrm{C}$. As SOFC pertencem, então, à classe de células a combustível de alta temperatura de operação, entre $800^{\circ} \mathrm{C}$ e $1.000^{\circ} \mathrm{C}$, portanto podem operar com qualquer tipo de combustível primário devido à alta temperatura de operação. Há uma forte tendência no desenvolvimento de um novo tipo destas células, denominado de ITSOFC (intermediate temperature SOFC), que deve operar na faixa de $650^{\circ} \mathrm{C}$ a $700{ }^{\circ} \mathrm{C}$ evitando-se, assim, os inerentes problemas tecnológicos associados a materiais que trabalham a elevadas temperaturas [3].

As células de alta temperatura de operação apresentam como principais vantagens a insensibilidade ao $\mathrm{CO}$ e $\mathrm{CO}_{2}$ e a dispensa de metais nobres como catalisadores. Nas desvantagens encontram-se os problemas com os materiais [3]. 
$\mathrm{Na}$ TAB. 1 estão representados os diferentes tipos de células a combustível, bem como suas características principais [20].

TABELA 1 - Tipos de células a combustível

\begin{tabular}{|c|c|c|c|c|c|}
\hline Tipo & Eletrólito & $\begin{array}{l}\text { Faixa de } \\
\text { temp. }\left({ }^{\circ} \mathrm{C}\right)\end{array}$ & Vantagens & Desvantagens & Aplicações \\
\hline $\begin{array}{l}\text { Alcalina } \\
\text { (AFC) }\end{array}$ & $\begin{array}{l}\mathrm{KOH} \\
\left(\mathrm{OH}^{-}\right)\end{array}$ & $60-90$ & $\begin{array}{l}\text { Alta eficiência } \\
\text { (83\% teórica) }\end{array}$ & $\begin{array}{c}\text { Sensível a } \mathrm{CO}_{2} \\
\text { Gases ultra } \\
\text { puros, sem } \\
\text { reforma do } \\
\text { combustível }\end{array}$ & $\begin{array}{l}\text { Espaçonaves } \\
\text { Aplicações } \\
\text { militares }\end{array}$ \\
\hline $\begin{array}{l}\text { Membrana } \\
\text { (PEMFC) }\end{array}$ & $\begin{array}{l}\text { Polímero: } \\
\text { Nafion } \\
\left(\mathrm{H}_{3} \mathrm{O}^{+}\right)\end{array}$ & $80-90$ & $\begin{array}{l}\text { Altas densidade } \\
\text { de potência e } \\
\text { eficiências } \\
\text { Operação } \\
\text { flexível }\end{array}$ & $\begin{array}{c}\text { Custo da } \\
\text { membrana } \\
\text { potência e } \\
\text { eficiência } \\
\text { Contaminação } \\
\text { do catalisador } \\
\text { com CO }\end{array}$ & $\begin{array}{l}\text { Veículos } \\
\text { automotores e } \\
\text { catalisador } \\
\text { Espaçonaves } \\
\text { Mobilidade }\end{array}$ \\
\hline $\begin{array}{l}\text { Ácido } \\
\text { fosfórico } \\
\text { (PAFC) }\end{array}$ & $\begin{array}{l}\mathrm{H}_{3} \mathrm{PO}_{3} \\
\left(\mathrm{H}_{3} \mathrm{O}^{+}\right)\end{array}$ & $160-200$ & $\begin{array}{c}\text { Maior } \\
\text { desenvolvimento } \\
\text { tecnológico }\end{array}$ & $\begin{array}{c}\text { Controle da } \\
\text { porosidade do } \\
\text { eletrodo } \\
\text { Sensibilidade a } \\
\text { CO } \\
\text { Eficiência } \\
\text { limitada pela } \\
\text { corrosão }\end{array}$ & $\begin{array}{c}\text { Unidades } \\
\text { estacionárias (100 } \\
\text { kW a alguns MW) } \\
\text { Cogeração } \\
\text { eletricidade/calor }\end{array}$ \\
\hline $\begin{array}{l}\text { Carbonatos } \\
\text { fundidos } \\
\text { (MCFC) }\end{array}$ & $\begin{array}{l}\text { Carbonatos } \\
\text { Fundidos } \\
\left(\mathrm{CO}_{3}{ }^{2-}\right)\end{array}$ & $650-700$ & $\begin{array}{c}\text { Tolerância a } \\
\mathrm{CO} / \mathrm{CO}_{2} \\
\text { Eletrodos à base } \\
\text { de } \mathrm{Ni}\end{array}$ & $\begin{array}{c}\text { Problemas de } \\
\text { materiais } \\
\text { Necessidade } \\
\text { da reciclagem } \\
\text { de } \mathrm{CO}_{2} \\
\text { Interface } \\
\text { trifásica de } \\
\text { difícil controle }\end{array}$ & $\begin{array}{c}\text { Unidades } \\
\text { estacionárias de } \\
\text { algumas centenas } \\
\text { de kW. Cogeração } \\
\text { eletricidade/calor }\end{array}$ \\
\hline $\begin{array}{l}\text { Cerâmicas } \\
\text { (SOFC) }\end{array}$ & $\begin{array}{l}\mathrm{ZrO}_{2} \\
\left(\mathrm{O}^{2-}\right)\end{array}$ & 800-900 & $\begin{array}{c}\text { Alta eficiência } \\
\text { (cinética } \\
\text { favorável) } \\
\text { A reforma do } \\
\text { combustível } \\
\text { pode ser feita na } \\
\text { célula }\end{array}$ & $\begin{array}{l}\text { Problemas de } \\
\text { materiais } \\
\text { Expansão } \\
\text { térmica } \\
\text { Necessidade } \\
\text { de pré- reforma }\end{array}$ & $\begin{array}{c}\text { Unidades } \\
\text { estacionárias de } 10 \\
\text { a algumas } \\
\text { centenas de kW } \\
\text { Cogeração } \\
\text { eletricidade/ calor }\end{array}$ \\
\hline
\end{tabular}

Fonte: Adaptado de WENDT et al., 2000 [20]. 
As células a combustivel podem ser aplicadas para a geração estacionária de energia elétrica, para uso residencial, comercial e industrial; para a geração de energia nos meios de transporte em substituição ao motor de combustão interna, em caminhões, ônibus, automóveis, trens, navios e aviões; para a alimentação de equipamentos eletro-eletrônicos em substituição às baterias, nos telefones celulares, computadores, calculadoras, entre outros [21].

Segundo o Programa Brasileiro de Células a Combustível [21] uma das áreas mais promissoras para aplicações de células a combustível no país é a de sistemas para produção de energia elétrica de $5 \mathrm{~kW}$ a $200 \mathrm{~kW}$ para atender especialmente os casos de cargas essenciais, isto é, consumidores que necessitam de suprimento de energia elétrica com alto grau de confiabilidade. Esses consumidores são formados por empresas de telecomunicações, bancos, centros de pesquisa, hospitais, aeroportos, etc.

Outra área de potencial aplicação no Brasil é o fornecimento de energia elétrica para regiões isoladas [21]. Convencionalmente, as usinas têm sido unidades grandes e centralizadas. A nova tendência é o desenvolvimento em direção à geração de energia distribuída, que significa que as unidades de conversão de energia serão situadas próximas aos consumidores e as grandes unidades serão substituídas pelas menores [22]. Assim, a célula a combustível poderá ser uma ferramenta capaz de fornecer energia às áreas isoladas do Brasil.

As células a combustível ainda são caras, pois ainda não atingiram o ponto crítico em que economias de escala passam a se desenvolver e reduzem significativamente o custo por unidade manufaturada [23], mas como em outras tecnologias isso irá acontecer.

\subsection{Hidrogênio}

O hidrogênio é um gás incolor, insípido e inodoro. É um gás combustível, pois ao introduzir-se uma vela acesa numa proveta invertida contendo hidrogênio, este queima dando uma chama azul apenas visível na boca do recipiente, porém a vela se apaga, mostrando assim que o hidrogênio não é comburente. Comparado ao ar, seu peso específico é muito baixo, sendo somente de 0,069 e sua densidade normal é $0,08987 \mathrm{~g}$ por litro [24]. 
O seu emprego é crescente em operações industriais, porém seu uso mais importante reside na fabricação de amônia sintética e na hidrogenação dos óleos. É importante na produção de petróleo de carvão pela hidrogenação do carvão em presença de catalisador. Grandes quantidades também são usadas para o enchimento de balões e dirigíveis, uma vez que é o gás mais leve que se conhece e que torna o poder de ascensão destes considerável [24].

A utilização de hidrogênio como vetor energético representa uma alternativa que desperta crescente interesse e em torno do qual muitas pesquisas têm sido conduzidas. Apesar de ser o elemento mais abundante do universo o hidrogênio não existe na forma de molécula isolada necessitando, portanto, ser produzido [25].

O hidrogênio pode ser produzido a partir de diferentes fontes, divididas em três classes principais: combustíveis fósseis, fontes renováveis e eletrólise da água [1].

Os combustíveis fósseis representam, sem dúvida, a principal matériaprima para a produção de hidrogênio no cenário atual, sendo que o gás natural responde por $48 \%$ da produção mundial, o petróleo por $30 \%$ e o carvão por $18 \%$ [26]. É importante lembrar que, quando se utilizam combustíveis fósseis para produção de hidrogênio, o $\mathrm{CO}_{2}$ é um importante subproduto e quanto maior o hidrocarboneto, maior a produção relativa de $\mathrm{CO}_{2}$ [1]. As duas formas mais comuns de produzir hidrogênio a partir de fontes fósseis são conhecidas como "reforma a vapor" e "oxidação parcial de hidrocarbonetos pesados" [18].

Entre as fontes renováveis, o destaque tem sido a biomassa, a qual pode ser usada diretamente para a produção de hidrogênio a partir de processos de gaseificação e reforma [1].

A energia requerida para a eletrólise pode ser de origem nuclear ou a partir de fontes renováveis, como a hidroelétrica, solar, eólica ou gaseificação. Atualmente a eletrólise da água responde por apenas $4 \%$ da capacidade mundial de produção de hidrogênio, devido ao custo alto e a tecnologia ainda incipiente [1]. 
A produção do hidrogênio também pode ser biológica, sendo realizada por organismos fotossintéticos ou fermentativos. Com a manipulação genética a geração do hidrogênio pode ser aumentada. A produção biológica do hidrogênio pode ser realizada pelos processos de biofotólise, foto-fermentação ou fermentação no escuro [27].

\subsubsection{Produção de Hidrogênio a partir da biomassa}

O termo biomassa refere-se a produtos agrícolas e seus derivados como o etanol, ácidos graxos e glicerol, ou a rejeitos orgânicos constituídos de material em decomposição, como escuma de esgoto, lodos biológicos, etc. Quando é feita a gaseificação da biomassa há geração de $\mathrm{CO}_{2}$ no processo, porém como o $\mathrm{CO}_{2}$ é capturado pelas plantas durante o seu crescimento, o ciclo torna-se carbonicamente neutro [1].

A produção de hidrogênio pode ser realizada a partir de diferentes biomassas destacando-se entre elas:

\section{$\underline{\text { Lixo Urbano }}$}

O gás produzido nos aterros sanitários é proveniente da ação de microorganismos anaeróbicos no lixo orgânico gerado nas cidades. $O$ gás produzido normalmente contém metano $\left(\mathrm{CH}_{4}\right)$, dióxido de carbono $\left(\mathrm{CO}_{2}\right)$, nitrogênio e uma menor quantidade de hidrogênio e oxigênio. Se o metano não for utilizado na produção de energia poderá contribuir incisivamente para o efeito estufa, pois neste caso a ação do metano é 23 vezes mais eficaz do que a do $\mathrm{CO}_{2}[18]$.

Também há produção de ácido sulfídrico $\left(\mathrm{H}_{2} \mathrm{~S}\right)$. O envenamento com $\mathrm{H}_{2} \mathrm{~S}$, é considerado fatal para o desempenho da célula a combustível [18]. Concentrações entre 1-3 ppm de $\mathrm{H}_{2} \mathrm{~S}$ são suficientes para comprometer o funcionamento da célula, sendo o dano permanente [2], portanto é necessária a remoção deste composto. Assim um processo de reforma do metano associado à purificação do gás produzido poderá gerar uma grande quantidade de hidrogênio. 


\section{Gaseificação}

É um processo no qual o combustível sólido é convertido em gases pela combinação de processos de reações químicas. Existem vários tipos de gaseificadores com diferentes processos e diferentes misturas de gases podem ser obtidas [18]. A gaseificação produz o chamado "gás de síntese" composto, principalmente, por hidrogênio e monóxido de carbono. Assim, o gás resultante de um processo de gaseificação, que também pode ter outros compostos como metano e dióxido de carbono, deve ser submetido a um processo de purificação, dependendo da célula a combustível a ser utilizada.

\section{Biocombustíveis}

Poderão substituir aos poucos o uso de combustíveis não renováveis como o petróleo, que demora milhões de anos para ser formado. $O$ uso deste combustível renovável na obtenção de hidrogênio, por meio de um processo de reforma a vapor e a utilização deste gás em células a combustível será uma alternativa para se gerar energia limpa, sustentável, confiável, silenciosa e altamente eficiente [18].

\section{Biogás}

O biogás pode ser utilizado diretamente em algumas tecnologias de células a combustível que funcionam em alta temperatura $\left(600^{\circ} \mathrm{C}\right.$ a $\left.1000^{\circ} \mathrm{C}\right)$. Estas células são mais resistentes a alguns compostos presentes no biogás como o $\mathrm{H}_{2} \mathrm{~S}$ e o CO [18]. O biogás também pode ser convertido em hidrogênio puro - através de um sistema de purificação e ser usado em células a combustível de baixa temperatura. $O$ hidrogênio para estas células a combustível tem que ser o mais puro possível, uma vez que o catalisador utilizado - platina - é sensível ao monóxido de carbono (CO) formado na reação de obtenção do hidrogênio a partir do biogás [18].

\section{Amônia}

A amônia também pode ser uma fonte de hidrogênio e apresenta a vantagem de não conter carbono. É resultante, na natureza, da decomposição de matéria orgânica, por isso considerada uma fonte renovável. Em resíduos 
avícolas, é formada pela decomposição do ácido úrico. Dependendo do processo de obtenção da amônia podem ser produzidos outros gases, tornando-se necessário um processo de purificação.

\subsubsection{Purificação do Hidrogênio}

Um problema muito importante relacionado à eficiência das células a combustível está relacionado com a pureza do hidrogênio. Se o gás é produzido por eletrólise da água, a pureza é elevada e o catalisador de platina dispersa é plenamente satisfatório para promover com alta eficiência a reação de oxidação de hidrogênio que tem lugar no ânodo das células. Entretanto, se o hidrogênio é produzido através da reforma de outros combustíveis (gás natural, biogás, metanol, etanol, etc.), o produto pode vir acompanhado de impurezas tais como $\mathrm{CO}$ e compostos de enxofre (em níveis de $0,1 \%$ ) que se adsorvem fortemente sobre a platina, diminuindo de forma drástica a atividade do eletrocatalisador em temperaturas abaixo de $150^{\circ} \mathrm{C}[28]$.

O hidrogênio pode ser separado de outros gases por processos como a reação de deslocamento de vapor de água (WSA - water-gas shift reaction), a oxidação preferencial do CO (PROX), destilação criogênica, adsorção com modulação de pressão (PSA - Pressure Swing Adsorption) e membranas de separação seletiva [29].

A reação de Water-gas-shift (WGS) é freqüentemente utilizada nos processos químicos industriais para reduzir o nível de CO no gás de síntese proveniente da reforma. É descrita pela equação 3 [29].

$$
\mathrm{CO}_{(\mathrm{g})}+\mathrm{H}_{2} \mathrm{O}_{(\mathrm{g})} \leftrightarrows \mathrm{H}_{2(\mathrm{~g})}+\mathrm{CO}_{2(\mathrm{~g})} \quad \Delta \mathrm{H}=-41 \mathrm{kJmol}^{-1}
$$

$\mathrm{Na}$ oxidação preferencial do CO (PROX) uma pequena quantidade de oxigênio é adicionada ao gás proveniente da reforma para converter a baixa concentração remanescente de $\mathrm{CO}$ em $\mathrm{CO}_{2}$, sem converter quantidades significativas de $\mathrm{H}_{2}$ em $\mathrm{H}_{2} \mathrm{O}$ [29]. 
A destilação criogênica é aplicada para a separação de fluídos, tendo como princípio a diferença de pontos de ebulição dos componentes. $\mathrm{O} \mathrm{H}_{2}$ tem uma alta volatilidade relativa se comparada com a de hidrocarbonetos [29].

O processo PSA consiste na passagem de uma mistura gasosa, sob pressão, por um leito contendo um adsorvente de alta superfície específica que tem a função de aprisionar um determinado componente da mistura, deixando passar os demais. Com a despressurização do leito o componente retido é dessorvido e o adsorvente regenerado, voltando-se à condição inicial do processo [30].

As membranas permitem a separação seletiva ao hidrogênio e podem ser poliméricas, metálicas, carbônicas e cerâmicas. Fora as poliméricas, todas as demais são denominadas membranas inorgânicas [31].

\subsubsection{Manipulação do Hidrogênio}

Independente da fonte de hidrogênio, este combustível deve ser manipulado cuidadosamente. Parece haver um conceito generalizado de que o hidrogênio é mais perigoso do que outros tipos de combustíveis, porém quando realizada a comparação, a energia mínima de ignição do hidrogênio é menor que a do metano ou da gasolina e seu limite de ignição no ar é maior, mas qualquer um dos três combustíveis é inflamável por eletricidade estática ou fonte de calor moderada [1].

O hidrogênio apresenta as vantagens de ser extremamente leve, seu coeficiente de difusão no ar é bastante elevado e deste modo se dispersa mais facilmente, não produz fuligem durante a sua combustão e não é tóxico. $O$ fato de a chama do hidrogênio ser de difícil detecção pode ser resolvido com a adição de um colorante de forma a tornar a sua chama visível [1].

Um dos grandes desafios atualmente para a implantação da economia do hidrogênio é buscar soluções tecnológicas para seu transporte e armazenamento a custos competitivos. As principais dificuldades são a baixa densidade energética por unidade de volume e baixo ponto de condensação de hidrogênio [1]. 
O hidrogênio pode ser transportado na forma gasosa ou líquida. O meio de transporte pode ser através de tubulações (gasodutos ou tubulações criogênicas) ou por transporte rodoviário, ferroviário ou marítimo dos reservatórios utilizados para armazenar o hidrogênio, como cilindros pressurizados e reservatórios criogênicos [1]. Pode ser transportado, também, por meio de compostos intermediários, por exemplo, hidretos metálicos e a amônia.

\subsection{Amônia}

A amônia é um gás incolor, de odor irritante. Quando respirada repentinamente produz lacrimação e quando inalada em grandes concentrações pode produzir sufocação. $\mathrm{O}$ gás é extremamente solúvel em água, a $0^{\circ} \mathrm{C}$ e 760 $\mathrm{mm}$ um volume de água dissolve 1298 volumes do gás e a $20^{\circ} \mathrm{C}, 710$ volumes. Pode-se remover completamente o gás de suas soluções aquosas, aquecendoas. Liquefaz-se facilmente, para isso, é suficiente comprimi-la. O líquido entra em ebulição a $-33,5^{\circ} \mathrm{C}$ e solidifica-se a $-78^{\circ} \mathrm{C}$, dando cristais brancos e transparentes [24].

A amônia tem importantes aplicações. Pode ser utilizada para fins de refrigeração e sob a forma de sais, como o sulfato, é um fertilizante valioso e importante. É usada na fabricação de uréia (sendo a outra matéria-prima o dióxido de carbono), a qual é um fertilizante muito valorizado. É também empregada como agente de limpeza, devido à sua propriedade de dissolver graxas, na fabricação de soda pelo processo Solvay e em operações químicas em que se necessita um álcali volátil [24].

A aplicação da amônia neste trabalho deve-se ao seu alto conteúdo energético e de hidrogênio. O gás amônia como matéria-prima para produção de $\mathrm{H}_{2}$ tem sido utilizado pela sua facilidade de decomposição, elevada disponibilidade, baixo custo, pelas baixas pressões de armazenamento e pelos subprodutos do processamento serem ambientalmente corretos. Além disso, as tecnologias de estocagem, manuseio e transportes já estão estabelecidas [32].

A amônia pode ser produzida no processo de destilação de hulha ou ser sintetizada. Nas condições ordinárias, os gases nitrogênio e hidrogênio não regem entre si, porém quando se submete a ação de centelhas elétricas uma 
mistura na proporção de três volumes de hidrogênio para um de nitrogênio, eles reagem para formar amônia, na proporção de cerca de $2 \%$. Analogamente, submetendo-se a amônia gasosa a centelha elétrica, a decomposição se verifica, até que somente permaneçam cerca de $2 \%$ de amônia. O equilíbrio representado pela equação 4 acha-se, portanto, nestas circunstâncias, muito deslocado para a esquerda [24].

$$
\mathrm{N}_{2(\mathrm{~g})}+3 \mathrm{H}_{2(\mathrm{~g})} \leftrightarrows 2 \mathrm{NH}_{3(\mathrm{~g})}
$$

A formação de amônia a partir de seus elementos, é uma reação exotérmica conforme indicado na equação 5 .

$$
\mathrm{N}_{2(\mathrm{~g})}+3 \mathrm{H}_{2(\mathrm{~g})} \leftrightarrows 2 \mathrm{NH}_{3(\mathrm{~g})}+22,8 \mathrm{kcal}
$$

O processo industrial de síntese de amônia foi implantado por Haber e Bosch [24].

Uma das formas em que é encontrada na natureza é o resultado da quebra de uma ligação tripla covalente, de excepcional estabilidade, entre os dois átomos de nitrogênio, mais o hidrogênio extraído da água, formando duas moléculas de amônia na reação conhecida como fixação do nitrogênio [33, 34, 35]

No solo, a amônia é resultante da fixação do nitrogênio atmosférico por bactérias de vida livre do solo e da decomposição de materiais orgânicos complexos. Esta decomposição é realizada por bactérias que quebram os compostos nitrogenados em compostos simples. O nitrogênio resultante deste processo é então incorporado em aminoácidos e proteínas por esses organismos e o excesso liberado sob a forma de íons amônio pelo processo denominado amonificação ou mineralização do nitrogênio. Em meio alcalino, o nitrogênio pode ser convertido no gás amônia, mas essa conversão ocorre naturalmente apenas durante a decomposição de grandes quantidades de material rico em nitrogênio, como num acúmulo de excremento ou de adubo em contato com a atmosfera [36].

O aquecimento de compostos nitrogenados como hulha, couro, ossos, etc. também formam amônia. $O$ antigo nome da amônia - spiritus cornus cervi (espírito de chifre de cervo) - refere-se a um antigo costume de preparar amônia aquecendo os cascos e chifres de cervos em recipientes fechados [24]. 
Em Sistemas Produtivos de Frango de Corte a amônia é formada a partir da decomposição microbiana do ácido úrico (composto nitrogenado) eliminado pelas aves [37] e tem sua emissão incrementada pelos aumentos da temperatura, $\mathrm{pH}$ e umidade da cama [38] do tipo de material usado como cama e seu manejo [39].

\subsubsection{Amônia e hidrogênio}

O interesse pela amônia como fonte de hidrogênio pode ser em parte atribuído pelas suas vantagens potenciais, mas também pela falta de descobertas científicas e tecnológicas em outras áreas de produção e armazenagem de hidrogênio [40].

A amônia pode ser considerada um ótimo armazenador de hidrogênio, já que é: produzida ao mesmo custo do hidrogênio; está disponível em grandes quantidades e é distribuída em todo o mundo através de uma infra-estrutura já existente [4]. A densidade de energia de $8,9 \mathrm{kWh} \mathrm{kg}^{-1}$ da amônia pura é maior do que a do metanol $\left(6,2 \mathrm{kWh} \mathrm{kg}^{-1}\right)$ e menor do que a do diesel ou JP-8 $(13,2 \mathrm{kWh}$ $\left.\mathrm{kg}^{-1}\right)[5]$.

A amônia é um meio químico de armazenamento de hidrogênio como os hidrocarbonetos (gasolina ou diesel) ou alcoóis (ex. metanol). Sua decomposição é consideravelmente mais fácil do que a dos hidrocarbonetos e dos alcoóis, ocorre em um único passo reacional [5] e apresenta somente o nitrogênio como subproduto, ou seja, não há monóxido de carbono no gás produzido [6].

Em princípio, a amônia pura poderia ser utilizada como um meio de armazenamento de hidrogênio - pode ser condensada em líquido com pressão de $8 \mathrm{~atm}$ em temperatura ambiente, no entanto as emissões para o meio ambiente devem ser evitadas [6] por serem capazes de provocar irritação em concentrações maiores do que 20 ppm [41].

A toxicidade da amônia tem dificultado o seu uso como combustível em motores de combustão e em células a combustível. Essa dificuldade pode ser contornada com o uso de aminas metálicas para o armazenamento de hidrogênio [4]. 


\subsubsection{Sistema de armazenamento de amônia}

Pode-se, também, pensar em armazenar a amônia, transportá-la com segurança e utilizá-la, posteriormente, para a produção de hidrogênio.

A utilização de complexos de aminas metálicas para o armazenamento de hidrogênio envolve a amônia como um vetor energético intermediário. Complexos de aminas metálicas na forma $\mathrm{M}\left(\mathrm{NH}_{3}\right)_{n} \mathrm{X}_{\mathrm{m}}$ onde $\mathrm{M}$ é o cátion de metais como $\mathrm{Mg}^{2+}, \mathrm{Ca}^{3+}, \mathrm{Cr}^{3+}, \mathrm{Ni}^{2+}$ e $\mathrm{Zn}^{2+}$ e X é o ânion como $\mathrm{Cl}^{-}$ou $\mathrm{SO}_{4}{ }^{2-}$, são conhecidos por mais de um século [42]. Para os íons metálicos divalentes, os complexos de amina são geralmente formados facilmente conduzindo-se a amônia sobre o sal anidro $M X_{m}[6]$.

Christensen et al. [6] investigaram a possibilidade do uso do complexo $\mathrm{Mg}\left(\mathrm{NH}_{3}\right)_{6} \mathrm{Cl}_{2}$, por possuir a propriedade de ter a mesma densidade de volume da amônia líquida. $\mathrm{O}$ complexo $\mathrm{Mg}\left(\mathrm{NH}_{3}\right)_{6} \mathrm{Cl}_{2}$ armazenou $9,1 \%$ de peso de hidrogênio em forma de amônia. O armazenamento foi completamente reversível, o complexo foi considerado de fácil manuseio e combinando-o com a decomposição catalítica da amônia, o hidrogênio pôde ser obtido em temperaturas abaixo de $350^{\circ} \mathrm{C}$. A decomposição do complexo iniciou-se em torno de $80^{\circ} \mathrm{C}$ e em cerca de $230^{\circ} \mathrm{C}, 2 / 3$ da amônia havia sido liberada, sendo o restante liberado abaixo de $350^{\circ} \mathrm{C}[6]$.

Comparado com os hidretos metálicos, o sistema de amina metálica é caracterizado pela cinética de absorção e dessorção mais simples. Uma das razões é que, enquanto o $\mathrm{H}_{2}$ precisa dissociar-se antes da absorção para formar o hidreto, o $\mathrm{NH}_{3}$ absorve molecularmente. As pastilhas têm taxas de dessorção tão baixas que não é possível sentir o cheiro de amônia em temperatura ambiente mesmo que a pastilha seja segurada embaixo do nariz [6].

Ainda segundo o autor [6], a conversão da amônia dessorvida do meio de armazenagem sólido em $\mathrm{H}_{2}$ e $\mathrm{N}_{2}$ é razoavelmente simples, com a condução dessa amônia sobre um catalisador para realizar a sua decomposição. 


\subsubsection{Obtenção de hidrogênio por decomposição da amônia}

A decomposição térmica da amônia ocorre preferencialmente a baixas pressões e acontece em temperaturas mais baixas quando na presença de catalisadores. Um sistema geração de amônia - produção de hidrogênio célula a combustível permite a geração de energia estacionária com alto índice de qualidade, de alta confiabilidade, evitando-se os processos de armazenamento e transporte de hidrogênio [32].

A decomposição da amônia para a obtenção de hidrogênio foi apresentada por Sørensen et al. [40] através de uma unidade simples e minituarizada de reforma de amônia que pode ser utilizada em telefones celulares.

Utilizando-se catalisadores suportados em rutênio promovidos com bário, pôde ser produzido hidrogênio suficiente para uma célula a combustível de $1 \mathrm{~W}$ (correspondente ao consumo máximo de telefones celulares comuns) em um reator de apenas $20 \mu \mathrm{L}$ a $365^{\circ} \mathrm{C}$. A decomposição da amônia em sistemas minituarizados é possível, pois apresenta a vantagem, em relação aos compostos de armazenagem que contém carbono, de não formar monóxido de carbono durante a produção de hidrogênio, portanto não são requeridas unidades de purificação para a remoção deste gás [40].

O funcionamento da unidade minituarizada e compacta para produção de hidrogênio é mostrado no diagrama a seguir (FIG. 1). 


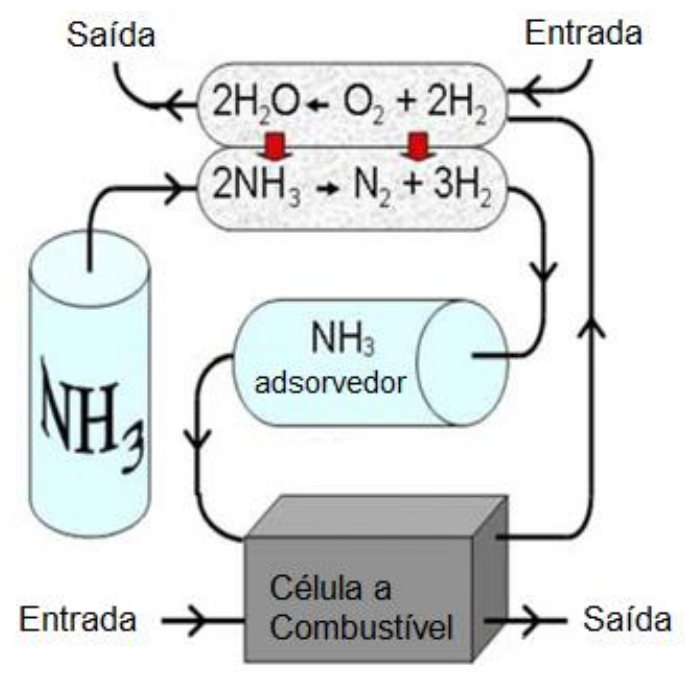

FIGURA 1 - Diagrama de fluxo para a produção de energia utilizando a amônia como combustível

Fonte: SØrensen et al., 2005 [40].

Primeiro, a amônia, em sua maior parte, é decomposta cataliticamente. Em seguida a amônia residual é removida por adsorção. O hidrogênio, resultante do craqueamento da amônia contém nitrogênio o que impede o seu consumo total na célula a combustível. Uma vantagem do sistema proposto é que o hidrogênio residual é cataliticamente queimado em outra câmera, em um micro reator, provendo o calor para a reação de decomposição endotérmica da amônia [40].

Obviamente, traços de amônia podem envenenar a membrana de células a combustível tipo PEM, mas esse envenenamento não é um problema prático já que a amônia pode ser removida através de uma simples adsorção ou lavagem ácida. Alternativamente, algumas células a combustível toleram impurezas da amônia, como a célula a combustível alcalina. Neste caso, um adsorvedor de amônia não é requerido e o calor necessário para a decomposição da amônia pode ser fornecido diretamente pela célula a combustível [40].

O recente trabalho publicado por Vyjayanthi et al. [5] mostrou que uma taxa de fluxo de 0,0009 mol.s ${ }^{-1}$ de amônia foi necessária, em associação com uma série de 20 células a combustível, para produzir $142 \mathrm{~W}$ de energia, dos quais 42 $\mathrm{W}$ foram utilizados para aquecer o reator e os outros $100 \mathrm{~W}$ disponíveis para uso externo, indicando uma eficiência de $70 \%$. Existe um custo de energia associado à produção de amônia que não foi considerado neste cálculo. Este projeto não foi 
considerado apropriado para aplicações em usinas de grande porte. Com a necessidade de utilizar $30 \%$ da energia gerada para a produção de hidrogênio, esta aplicação é mais adequada em usinas pequenas e em áreas remotas, como as comunidades rurais, as quais não são conectadas a uma rede de distribuição elétrica, mas tem diversas fontes de amônia ao alcance.

\subsection{Sistemas Produtivos de Frango de Corte e Ovos}

A dimensão da geração de amônia e do gasto de energia elétrica em sistemas produtivos de frango de corte e de ovos está diretamente relacionada com a produção de cada um desses empreendimentos.

Segundo dados do IBGE - Instituto Brasileiro de Geografia e Estatística [43], no $1^{\circ}$ trimestre de 2010, a pesquisa trimestral do abate de animais registrou 1,206 bilhões de unidades de frangos abatidos, indicando uma estabilidade no volume de produção em relação ao trimestre imediatamente anterior. $\mathrm{O}$ aumento do abate registrado foi de $7,3 \%$ quando comparado $01^{\circ}$ trimestre de 2010 e o mesmo período em 2009 [43].

Em equivalente peso de carcaça, o resultado obtido indica estabilidade, já que com 2,529 milhões de toneladas, a variação percentual entre os dois últimos períodos trimestrais foi praticamente nula $(0,1 \%)$. Quando a comparação é feita com relação ao mesmo trimestre do ano anterior, a pesquisa mostra crescimento de $7,9 \%$ [43].

No âmbito externo houve o registro de comercialização de 769.940 mil toneladas de carne de frango no $1^{\circ}$ trimestre de 2010 . O preço médio da tonelada de carne de frango foi de $U \$ 1.602$, enquanto que no trimestre imediatamente anterior atingiu U\$1.573. Mesmo com esse aumento do preço médio, o volume exportado e o faturamento apresentaram decréscimo de $6,7 \%$ e 5,0\%, respectivamente. Em relação ao $1^{\circ}$ trimestre de 2009 , registrou-se um aumento de $21,5 \%$ do volume exportado e de $24,9 \%$ do faturamento [43].

A produção de ovos de galinha no $1^{\circ}$ trimestre de 2010 foi de 600.704 milhões de dúzias. Com este resultado observou-se certa estabilidade da produção $(0,1 \%)$ com relação ao $4^{\circ}$ trimestre de 2009 e aumento de $3,5 \%$ com relação ao mesmo trimestre do ano anterior [43]. 
Observando o desempenho da produção desde $\circ 1^{\circ}$ trimestre de 2007, verifica-se crescimento contínuo durante todos os trimestres da série. Em termos estaduais, variações significativas foram sentidas no Mato Grosso, com uma expansão de produção de $84,1 \%$ sobre o $1^{\circ}$ trimestre de 2009 . Por outro lado, o Distrito Federal teve queda da produção de ovos de galinha de $29,7 \%$ no período em comparação. São Paulo foi a maior produtora nacional com $30,4 \%$ da produção [43].

Os dados do IBGE podem ser visualizados na TAB. 2.

TABELA 2 - Produção de frangos e de ovos no Brasil no primeiro trimestre de 2010

\begin{tabular}{cccc}
\hline \multirow{2}{*}{$\begin{array}{c}\text { Primeiro } \\
\text { Trimestre de } \\
2010\end{array}$} & \multicolumn{3}{c}{ Produção } \\
\cline { 2 - 4 } & $\begin{array}{c}\text { Número de } \\
\text { cabeças abatidas }\end{array}$ & $\begin{array}{c}\text { Peso Total das } \\
\text { carcaças }\end{array}$ & $\begin{array}{c}\text { Produção de ovos de } \\
\text { galinha (mil dúzias) }\end{array}$ \\
\cline { 2 - 4 } & 386.758 .753 & 810.593 .698 & 203.207 \\
Janeiro & 375.964 .761 & 785.867 .807 & 190.698 \\
Fevereiro & 443.788 .939 & 932.775 .308 & 206.799 \\
Março & 1.206 .512 .453 & 2.529 .236 .813 & 600.704 \\
TOTAL & & & \\
\hline
\end{tabular}

Fonte: Adaptado do IBGE, 2010 [43].

A evolução da avicultura industrial e sua expansão em diversas áreas do Brasil, principalmente na primeira década do século XXI, está relacionada às dinâmicas dos espaços rurais influenciadas por demandas comerciais e produtivas. A avicultura e outros segmentos agroindustriais vêm passando por modificações no processo produtivo, decorrentes de inovações tecnológicas que visam aumentar a produtividade e o faturamento das indústrias [44]. 
Criaram-se condições ambientais artificializadas na medida em que o progresso tecnológico propiciou maior controle produtivo. Um exemplo é a criação adensada de frangos em galpões climatizados [44].

Os sistemas produtivos de frango de corte baseiam-se no confinamento da ave por aproximadamente 45 dias. A criação de frangos em alta densidade, alojando de 16 a 20 frangos por metro quadrado, visa a um rendimento produtivo superior a $30 \mathrm{~kg}$ de carne por metro quadrado, o que possibilita uma melhor relação custo/benefício para o produtor [45]. O animal é criado sobre um material utilizado como piso, ou cama.

As principais despesas desse empreendimento referem-se aos gastos com a ração, produção de frangos, material utilizado como cama, água, gás liquefeito de petróleo - GLP, energia elétrica, combustíveis, mão-de-obra, máquinas e implementos e instalações e equipamentos [46].

Santos e Lucas Júnior, 2004 [46] realizaram um estudo sobre o balanço energético em galpão de frango de corte. As estimativas de entradas e saídas de energia foram obtidas durante o acompanhamento de oito lotes de frango de corte. O consumo médio de energia dos oito lotes, da granja em estudo, foi de $2.647,4$ kWh. Os equipamentos elétricos utilizados no galpão são o silo para armazenagem de ração, o sistema de alimentação para distribuição da ração, lâmpadas, comedouros tipo calha, sistema de nebulização, ventiladores e bomba de alta pressão [46].

O sistema de produção de poedeiras em gaiolas surgiu em meados de 1920, trazendo inúmeras vantagens como menor número de ovos sujos e quebrados e eliminação do uso de materiais para cama [47].

Atualmente, o sistema automatizado, também conhecido como sistema de baterias verticais, já substitui cerca de $7 \%$ dessas instalações no Brasil. Nele, a estrutura de sustentação é vertical e as gaiolas são de mesmo tamanho e unidas. O excremento produzido junto a outros resíduos caem, por gravidade, em esteiras únicas que ficam abaixo das gaiolas. Por estas esteiras o excremento é transportado para fora do galpão por meio de sistema automatizado [47]. A FIG. 2 é um exemplo de produção de poedeiras em gaiolas. 


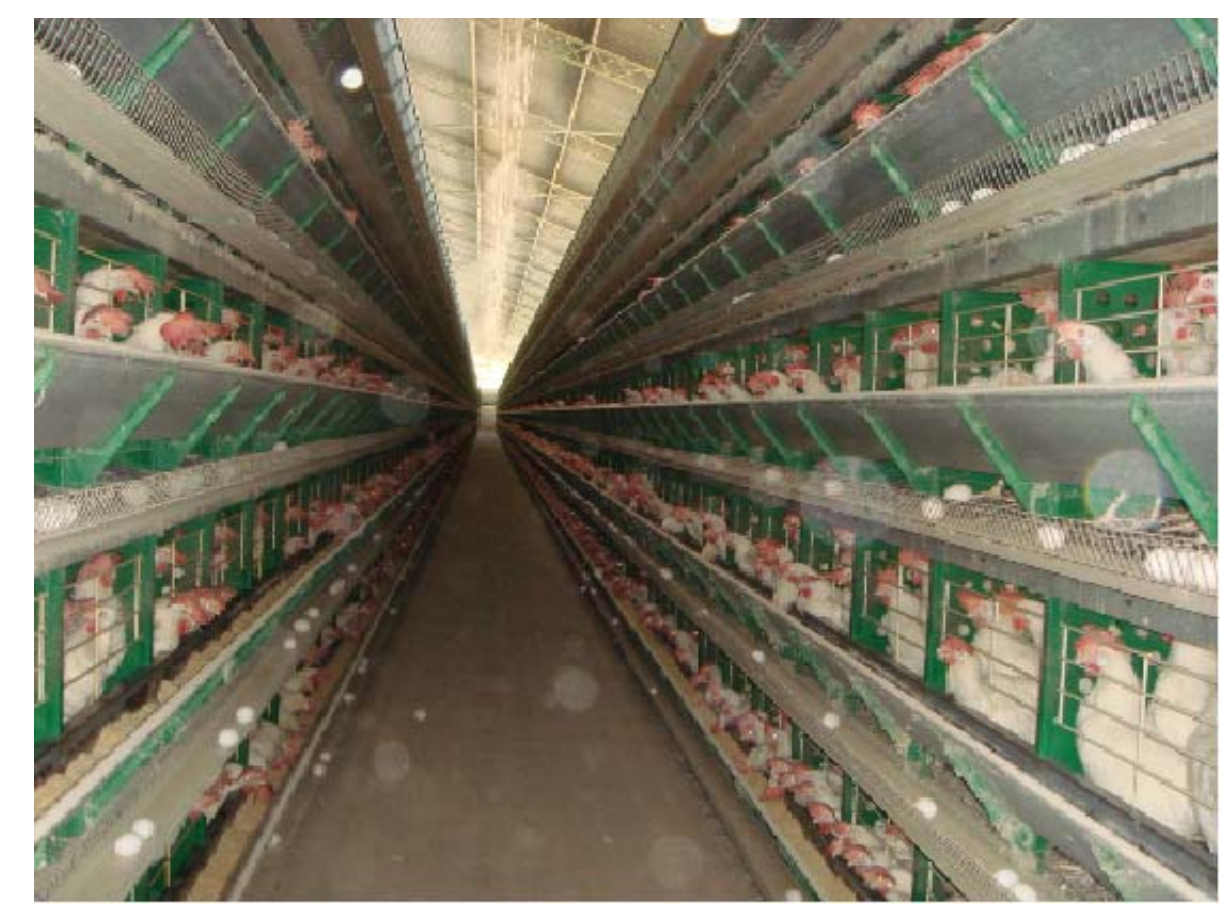

FIGURA 2 - Sistema automatizado de produção de poedeiras em gaiolas, no qual as excretas são transportadas por esteiras

Fonte: Arquivo pessoal, 2010.

A automatização dos sistemas produtores de ovos aumentou o consumo de energia elétrica. Além das despesas citadas para os sistemas produtivos de frango de corte, que podem ser aplicadas à produção de ovos, adiciona-se o consumo de energia das esteiras que retiram as excretas.

\subsubsection{Resíduos avícolas}

No corpo do animal, os materiais absorvidos são utilizados para sua manutenção e para a formação de novos tecidos. A manutenção consiste na produção de energia e na reposição de materiais desgastados, dela resultando como principais produtos o gás carbônico, a água e os excrementos nitrogenados [48].

Os excrementos resultam da passagem do alimento pelo trato digestivo dos animais. Assim, sua dinâmica química e biológica é função da natureza do material ingerido, do que o animal digere e do fracionamento mecânico e químico que o animal opera [48]. 
Para as poedeiras e frangos de corte a alimentação consiste, em nosso meio, de milho e farelo de soja, com pequenas quantidades de outros componentes. A composição e a dinâmica química e biológica das excreções dessas aves diferem pelo seu sistema de excreção de nitrogênio [48].

Para economizar água, as aves, como muitos animais que se originaram em ambientes secos, desenvolveram sistemas de excretar nitrogênio em substâncias sólidas, das quais a mais comum é o ácido úrico. Numa típica excreção de galinha, observa-se uma placa inferior maior e mais escura, encimada por outra menor e branca. A mancha maior são as fezes e a menor e branca é de ácido úrico, por assim dizer, a "urina" da ave. Por incluir as fezes e a "urina", as excreções frescas das aves são mais ricas em nitrogênio do que as de suínos ou bovinos [48].

O resíduo proveniente dos sistemas produtivos de frango de corte é a cama de frango. A cama de frango é um produto resultante da acumulação do excremento avícola, penas e alimento desperdiçado sobre um material usado como piso. É uma fonte de nitrogênio não protéico de baixo custo e disponível em grande quantidade no Estado de São Paulo [49].

A composição químico-bromatológica da cama de frango varia de acordo com o tipo de material utilizado para piso, tempo de criação, número de lotes criados no mesmo piso, número de aves por metro quadrado, tempo de estocagem [49], temperatura do ambiente e utilização de equipamentos de resfriamento como nebulizadores e ventiladores [50]. O tipo da ração também influencia na composição e determinava o valor nutritivo da cama quando esta era utilizada na alimentação animal [51].

Para estimar a produção anual da cama de frango considera-se que um frango de corte produza $1,5 \mathrm{~kg}$ de excremento durante o período de criação, adicionando-se ainda o peso do material utilizado como piso [52].

Um material para cama eficaz deve ser absorvente, de peso leve, barato, não tóxico, com alta absorção de umidade e propriedades capazes de minimizar a formação de placas na cama [53]. Na FIG. 3 apresenta-se uma imagem de frangos criados sobre o material utilizado como piso. 


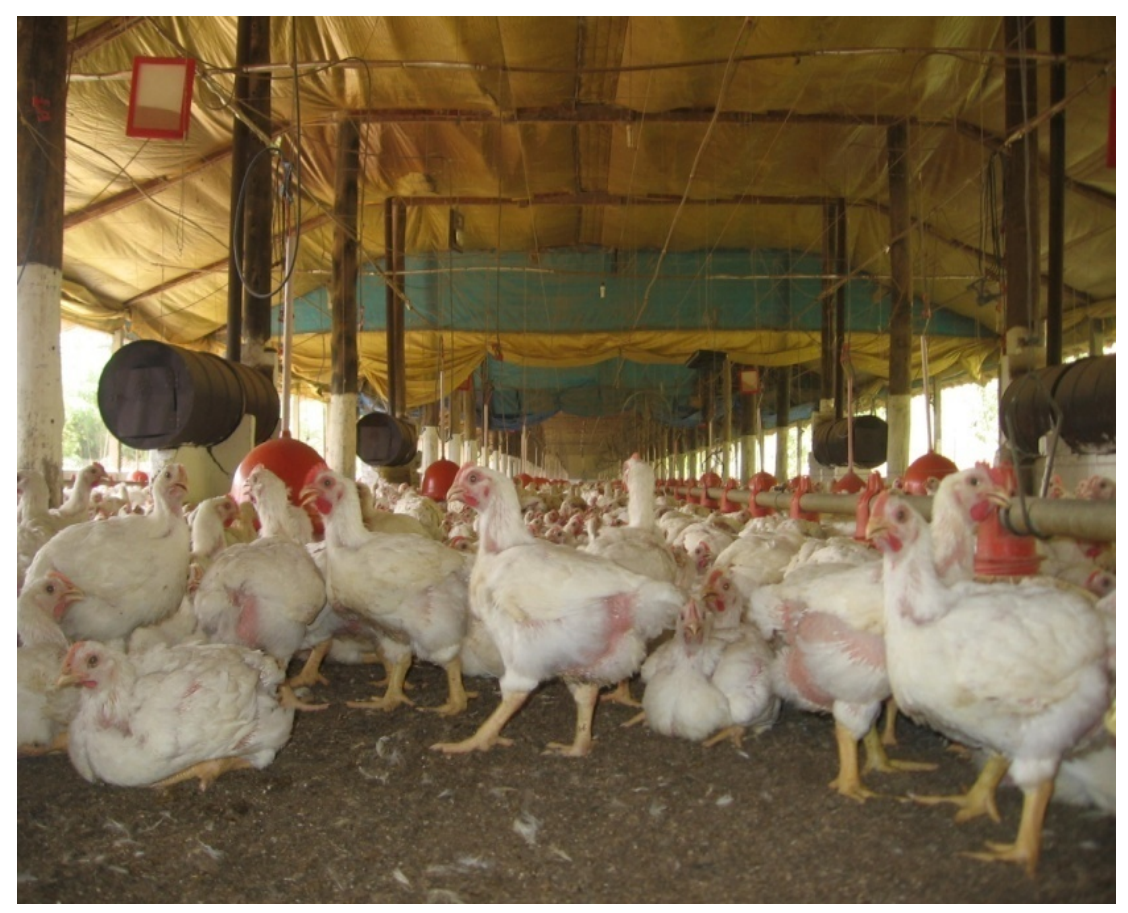

FIGURA 3 - Imagem de frangos criados sobre o material utilizado como piso (cama de frango)

Fonte: Arquivo pessoal, 2009.

Muitos produtos têm sido utilizados como piso. A qualidade e a quantidade do material utilizado como cama pode variar muito de região para região. Na TAB. 3 são listados alguns materiais que têm sido testados com pelo menos algum grau de sucesso e se discute brevemente as vantagens e as desvantagens das diferentes fontes de cama. Periodicamente alguns subprodutos de empresas têm despertado interesse como material de cama. 
TABELA 3 - Vantagens e desvantagens de materiais usados como cama nas granjas avícolas

\begin{tabular}{ll}
\hline $\begin{array}{l}\text { Serragem ou } \\
\text { É o material preferido, mas está se tornando uma fonte } \\
\text { madeira }\end{array}$ & limitada e cara em algumas áreas.
\end{tabular}

Um bom material quando disponível em preços

Casca de arroz competitivos. Frangos novos podem ser propensos a comer o material, sem graves conseqüências.

Casca de amendoim

Material barato em áreas produtoras de amendoim. Tende a incrustação. Suscetível ao crescimento de fungos e a incidência de aspergilose. Problemas com pesticidas foram notados no passado.

Experimentos mostraram desempenho comparável com raspas de madeira. Porém, quando reutilizado apresentou incrustações. Maior dificuldade em manter Areia temperaturas adequadas durante o inverno. É necessária uma ventilação prolongada para assegurar a secagem.

Papel

processado

Várias formas de papel processado são bons materiais para cama em situações comerciais e de pesquisas. Cuidados no manejo são essenciais.

Fonte: Ritz et al., 2005 [53].

O resíduo proveniente dos sistemas produtivos de ovos é a excreta, sem qualquer material utilizado como substrato. A composição desse resíduo consiste no excremento da galinha, de penas, ovos quebrados, restos de ração, larvas de moscas; além de corpos estranhos tais como, pregos, pedaços de arame, 
madeira dentre outros [54]. Já a composição de nutrientes varia conforme o tipo de exploração, linhagem genética, densidade populacional das aves, tempo de permanência dos dejetos no galpão e conforme a composição da ração consumida [55].

Augusto [56] quantificou a produção de dejetos em instalações automatizadas de produção de ovos. O valor obtido foi de $0,10 \mathrm{~kg} / \mathrm{ave} / \mathrm{dia}$.

Em ambos os sistemas produtivos os animais são criados em confinamento, portanto a qualidade do ar do interior dos galpões é um fator importante na produção. As altas concentrações de amônia no interior dos galpões afetam o desempenho das aves. A emissão de amônia será a primeira preocupação desses sistemas produtivos para estar em conformidade com as normas de controle [9].

\subsection{Emissões de amônia}

A amônia é formada a partir da decomposição microbiana do ácido úrico (composto nitrogenado) eliminado pelas aves [37]. Existem cinco etapas enzimáticas na degradação aeróbica do ácido úrico. Primeiramente o ácido úrico, forma dominante de nitrogênio nas excretas, é convertido em alantoína pela enzima uricase. Na segunda etapa, a alantoína é convertida em ácido alantóico pela alantoinase. Na terceira etapa o ácido alantóico é convertido em ureidoglicolato pela alantoato amidohidrolase. $\mathrm{Na}$ quarta etapa o ureidoglicolato é convertido em glioxilato e uréia pela ureidoglicolase. A última etapa consiste na hidrólise da uréia em amônia e $\mathrm{CO}_{2}$ pela enzima urease [57].

Segundo Felix e Cardoso [58] os resíduos de animais domésticos são a segunda maior fonte de amônia. Esse dado pode ser visualizado na TAB. 4 . 
TABELA 4 - Estimativa das fontes e sorvedouros da amônia atmosférica

\begin{tabular}{cc}
\hline Fontes e sorvedouros & $\begin{array}{c}\text { Quantidade de amônia } \\
\left(\operatorname{Tg~N~ano}{ }^{-1}\right)^{*}\end{array}$ \\
\hline Queima de combustíveis fósseis & 2 \\
Queima da biomassa & 5 \\
Superfície marinha & 13 \\
Resíduo de animal doméstico & 32 \\
Excremento humano & 4 \\
Emissões do solo & 19 \\
Deposição úmida & 46 \\
Deposição seca & 10 \\
Oxidação pelo radical $\mathrm{OH}$ & 1 \\
\hline
\end{tabular}

${ }^{*} \mathrm{Tg}=10^{12} \mathrm{~g}$

Fonte: Felix e Cardoso, 2004 [58].

\subsubsection{Estimativa da taxa de emissão de amônia}

A estimativa precisa da taxa de emissão de amônia dos sistemas produtivos é importante tanto para as agências regulatórias como para os produtores de animais [9].

Em todo o mundo numerosos estudos têm sido publicados sobre a emissão de amônia em sistemas produtivos de frango. Uma ampla variação nos resultados tem sido encontrada entre os diferentes estudos e até mesmo entre as medidas em um mesmo estudo. Essas variações são resultantes da dependência aos fatores sazonais e das condições regionais, do desenho do galpão e das práticas de administração [9].

A grande variação nos valores dessas emissões faz da quantificação das taxas de emissão de amônia dos sistemas produtivos de frango de corte um processo complexo [9]. 


\subsubsection{Modelos de emissão}

A fim de aperfeiçoar a precisão e a simplicidade da estimativa das emissões de amônia, vários modelos de emissão foram desenvolvidos. Os modelos descritos neste item, embora não utilizados neste trabalho, poderão auxiliar em uma futura estimativa da emissão de amônia proveniente dos resíduos que serão manipulados com o intuito de aumentar essa emissão.

Os objetivos principais dos modelos de emissão são citados a seguir [9]:

1. Determinar as emissões de amônia, utilizando-se a atual abordagem de medida e sob a ventilação das granjas comerciais, é um processo difícil e caro. Com os modelos de emissão os usuários podem calcular as emissões localizadas, utilizando o design local e os parâmetros de operação;

2. Os modelos de emissão podem ser utilizados para quantificar e avaliar a efetividade das estratégias de controle de emissão adotadas. Utilizando-se as atuais metodologias, avaliar os efeitos das estratégias em toda a escala de produção requer mão-de-obra intensiva e um custo alto;

3. Estimativas razoáveis das taxas de emissão de amônia das granjas são necessárias para guiar discussões sobre o impacto da indústria na qualidade do ar regional e local. Alguns inventários de emissão não caracterizaram adequadamente as variações geográficas e sazonais. Os modelos de emissão podem ser utilizados para simular essas variações nos fatores de emissão.

Os modelos mecanicistas provêm o entendimento físico e químico como também a descrição quantitativa da liberação de amônia. Existem muitos submodelos utilizados na abordagem mecanicista. Alguns modelos são empíricos, os quais descrevem de maneira simples as correlações estatísticas entre as emissões de amônia e vários fatores influentes. Os modelos de balanço de massa e os modelos de dispersão inversa são modelos de cálculo que provêm métodos alternativos para estimar as emissões. Modelos de base processual consideram cada um dos processos que ocorrem em um típico criadouro de animais e calculam a emissão de amônia para cada um deles. Modelos de fluxo de 
nitrogênio simulam o nitrogênio amoniacal total sobre 0 fluxo de diferentes estágios de emissão (alojamento, armazenamento de excremento e aplicação) [9].

O modelo geral e os modelos descritos acima serão apresentados a seguir.

\subsubsection{Modelo Geral}

A produção e emissão de amônia envolvem muitos processos biológicos, químicos e físicos. A FIG. 4 ilustra os principais processos relacionados com a emissão de amônia da cama de frango. Esses processos incluem: a geração da amônia, a divisão entre a fase adsorvida e a fase aquosa de íons amônio, o equilíbrio entre os íons amônio e a amônia livre na solução aquosa, a divisão entre a fase sólida/aquosa e a fase gasosa da amônia e a transferência convectiva de massa do gás amônia da superfície da cama de frango para a fase gasosa - atmosfera ambiente [9].

A amônia na cama de frango é gerada pela decomposição química e microbiana do ácido úrico após a excreção [9]. Os íons amônio $\left(\mathrm{NH}_{4}{ }^{+}\right)$na cama são distribuídos na fase adsorvida e na dissolvida. A amônia dissolvida na camada líquida da superfície da cama pode existir na forma de íons amônio e de amônia livre, o que pode ser expresso com a constante de dissociação $K_{d}$. A constante de Henry $K_{h}$ descreve o equilíbrio entre a amônia livre na fase aquosa e na fase gasosa. Com a transferência convectiva de massa, parte da amônia gasosa da superfície da cama de frango é transferida para atmosfera do criadouro [9]. 


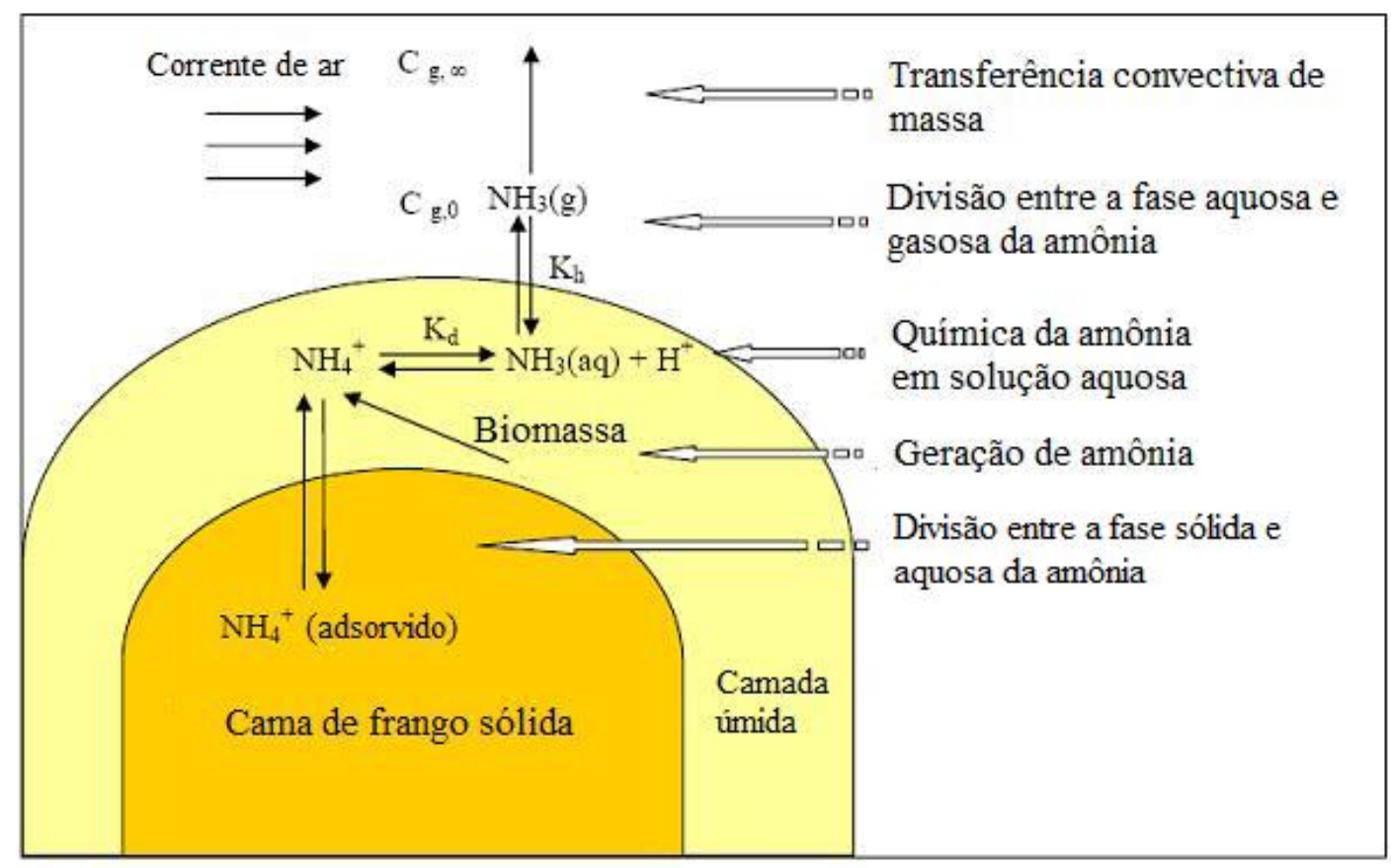

FIGURA 4 - Ilustração dos processos relacionados com as emissões de amônia da cama de frango

Fonte: Liu et al., 2006 [9].

O processo de emissão de amônia da cama de frango é essencialmente o transporte da fase aquosa ou fase sólida da amônia para a fase gasosa na atmosfera. Para o sistema de transporte interfásico, há muitas teorias propostas, incluindo a "Two film theory" de Welty, 1984 e a "Boundary layer theory" de Olesen e Sommer, 1993, que originam uma equação geral do fluxo da transferência de massa [9], a qual pode ser visualizada na equação 6.

$$
J=K_{m}\left(C_{g, 0}-C_{g, \infty}\right)
$$

onde,

J: fluxo de emissão

$\mathrm{K}_{\mathrm{m}}$ : coeficiente de transferência de massa

$\mathrm{C}_{\mathrm{g}, 0}$ : concentração da fase gasosa da amônia na superfície da cama de frango

$\mathrm{C}_{\mathrm{g}, \infty}$ : concentração da fase gasosa na atmosfera 
$\mathrm{Na}$ equação anterior, o fluxo da amônia é essencialmente função da transferência de massa, da concentração da amônia na fase gasosa na superfície da cama e da concentração da amônia na fase gasosa na corrente de ar. Para estimar o fluxo da amônia, a tarefa mais importante é determinar o coeficiente de transferência de massa e a concentração da amônia na fase gasosa na superfície da cama [9].

A determinação do coeficiente de transferência de massa é primariamente empírica. Ni [59] estimou o coeficiente convectivo de transferência de massa, com variação de $1,0 \times 10^{-4}$ a $2,3 \times 10^{-3}$ m.s. $\mathrm{s}^{-1}$, dos dados de seis meses das medidas de campo em um sistema de produção de suínos. Os coeficientes de transferência de massa obtidos em diferentes experimentos de emissão de amônia variaram amplamente.

A determinação da concentração da amônia na fase gasosa na superfície do excremento é mais complexa. Esta pode ser influenciada pelo equilíbrio entre a fase gasosa e a aquosa da amônia, e a química aquosa da amônia. A concentração da amônia gasosa na superfície da cama basicamente depende das condições da cama [9].

\subsubsection{Outros modelos}

\section{Modelo Mecanicista}

Os modelos mecanicistas consideram os principais processos químicos e físicos na determinação da amônia e são capazes de descrever a variação temporal das emissões. Os modelos de emissão dos galpões criadores de animais descritos por Hutchings [60] e Pinder et al. [61] utilizam a equação 7 para calcular a emissão instantânea de amônia.

$$
\text { Emissões }=\mathrm{A}[\mathrm{TAN}] \mathrm{H}^{*} \mathrm{r}^{-1}
$$

Onde: A é a área de exposição do excremento; TAN é a concentração total de nitrogênio amoniacal do excremento; $\mathrm{H}^{*}$ é a constante efetiva de Henry, que determina a divisão entre a amônia na fase gasosa e TAN; e r é a resistência à transferência de massa. A fonte de TAN é a excreção animal. Cálculos da $H^{*}$ requerem o conhecimento da temperatura e do $\mathrm{pH}$ do excremento. Essa 
resistência é a soma da aerodinâmica quase-laminar, e da resistência da superfície.

Na equação 8 é mostrada outra maneira de se estimar as emissões de amônia dos galpões [62].

$$
\text { Taxas de emissão }=\mathrm{Q}\left(\mathrm{C}_{\text {house }}-\mathrm{C}_{\text {out }}\right)
$$

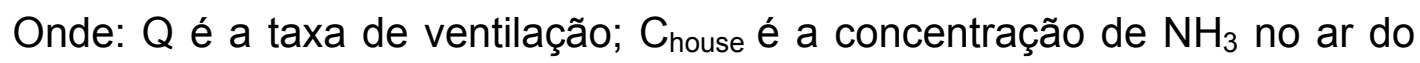
interior do galpão; $\mathrm{C}_{\text {out }}$ é a concentração de $\mathrm{NH}_{3}$ no ar do exterior do galpão. $\mathrm{O}$ balanço de massa é utilizado para derivar equações diferenciais para o cálculo da concentração de amônia no ar do interior do galpão. O balanço energético foi utilizado para predizer a temperatura e a taxa de ventilação do interior do galpão, que foram incorporadas no cálculo da taxa de emissão de amônia. O submodelo mecanicista de ventilação foi utilizado para calcular a taxa de ventilação [62].

O submodelo de ventilação assume que o objetivo do manejo é manter a temperatura interna em um valor apropriado para as espécies animais [9].

O submodelo de excreção de nitrogênio considera que a concentração total de nitrogênio amoniacal é a excreção animal. Esses submodelos têm sido propostos para calcular a excreção nitrogenada em resposta ao tipo e a etapa de criação, taxas de alimentação, produtividade e práticas de manejo animal [62].

\section{Modelos Empíricos}

Os modelos empíricos simplesmente descrevem as correlações estatísticas entre os principais parâmetros e os fatores influentes selecionados. Eles podem ser utilizados diretamente para estimar as emissões e também podem ser úteis na avaliação da exatidão das medidas da abordagem mecanicista.

Utilizando o procedimento SAS GLM, Carr et al. [63] desenvolveram um modelo semilogaritmo, que mostra que a concentração de amônia aumenta com a elevação do pH da cama, temperatura e teor de umidade da cama.

\section{Modelos de Balanço de massa}

No modelo de balanço de massa, o total de entrada e saída de nitrogênio é quantificado e a diferença entre o que entra e o que sai é aceito como nitrogênio 
volatilizado. Este método não distingue perdas de nitrogênio nas formas de $\mathrm{N}_{2}$ ou $\mathrm{NO}_{x}$. Também não poderia predizer ciclos diários nas emissões ou concentrações máximas. Contudo, pode fornecer uma estimativa exata dos limites superiores das emissões de amônia sobre longos períodos de produção [64]. A abordagem de balanço de massa é simples, tem como característica o baixo custo e aparece como um método promissor de fornecer exatidão nas estimativas das emissões de amônia em longos períodos nas unidades de produção de frango de corte.

\section{Modelos de dispersão inversa}

O modelo de dispersão inversa tem sido desenvolvido para medir as emissões de amônia dos galpões de frango de corte. As amostras passivas são posicionadas em determinada ordem a favor dos ventos nos galpões de criação. Um modelo Lagrangiano, inverso do modelo de dispersão tipo pluma Gaussiana é adaptado a um perfil de concentração de amônia, observado para determinar o total de emissão de amônia do galpão. Normalizar este valor para o número de aves permite o cálculo do fator de emissão correspondente ao período de amostragem. A principal vantagem dessa abordagem é que ela permite a determinação da emissão de amônia em vários estágios de crescimento nas condições reais de criação [65].

\section{Modelos de base processual}

Determinados processos do empreendimento animal são mais importantes para as emissões do que outros. O desenvolvimento de um modelo de base processual possibilita realizar análises do sistema e simulações para determinar os pontos críticos de controle das emissões [66]. Pode também realçar áreas de pesquisa vantajosas e identificar lacunas de conhecimento que precisam ser preenchidas a fim de aprimorar o entendimento de todos os processos de uma fazenda [9].

\section{Modelos do fluxo de nitrogênio}

Modelos de fluxo de nitrogênio por conservação de massa, como o DYNAMO (Dynamic Ammonia Emission Model), iniciam com uma específica quantidade de nitrogênio $(N)$ excretado por uma categoria definida de animais e simula o fluxo da concentração total de nitrogênio amoniacal (TAN) nos diferentes 
estágios de emissão (alimentação, período de criação, armazenamento do excremento e aplicação). Em cada estágio do manejo do resíduo, a proporção da TAN será subtraída da TAN total, principalmente como $\mathrm{NH}_{3}$ emitida e o restante irá para o próximo passo. As emissões de amônia são geralmente calculadas com o fator de emissão, esse fator é o percentual da respectiva concentração de nitrogênio amoniacal emitida [9].

\subsection{Fatores que influenciam a emissão de amônia}

Os fatores se influenciam mutuamente, no entanto serão abordados separadamente. Os fatores relacionados à cama de frango aplicam-se aos sistemas produtivos de frango de corte, os demais se aplicam também aos sistemas de produção de ovos (criação de galinhas poedeiras).

\section{Materiais utilizados como cama}

A opção por esses materiais depende da disponibilidade, da qualidade, do custo ou da finalidade de sua utilização após o período de criação das aves [67].

Oliveira et al. [68], compararam dois tipos de material, a serragem e a maravalha de madeira. A principal diferença entre esses materiais é a granulometria, a qual interfere na absorção de água. A volatilização de amônia da serragem foi maior do que a da maravalha. Quando a maravalha de madeira foi comparada com a casca de amendoim por Lien et al. [69], a quantidade de amônia volatilizada da maravalha também foi menor.

Atapattu et al. [70] comparam três tipos diferentes de material utilizado como cama: chá, serragem e casca de arroz. A emissão de amônia da cama composta de chá apresentou menores valores.

\section{$\underline{\text { Teor de nitrogênio }}$}

O teor de nitrogênio da cama é diretamente relacionado com a emissão de amônia. Um aumento no nível de proteína na alimentação eleva significantemente o teor de nitrogênio da cama e, por conseguinte, a taxa de emissão da amônia. Elwinger and Svensson [71], reportaram que o teor de nitrogênio na cama de frango ao final do período de criação foi de $45 \mathrm{~g} / \mathrm{kg}$ de matéria seca; para camas, não usadas, de maravalha de madeira foi de $1,0 \mathrm{~g} / \mathrm{kg}$ de matéria seca; para 
camas, não usadas, compostas de palha de trigo foi de 4,6 g/kg de matéria seca. Com esses experimentos, foi possível concluir que o teor de nitrogênio na cama de frango é proveniente do excremento e não do material utilizado como piso. Sims e Wolf [72] reportaram que mais de 50\% do nitrogênio da cama de frango pode ser volatilizado na forma de amônia.

\section{$\underline{\text { Sexo das aves }}$}

Em relação ao sexo, Neme et al. [73] observaram diferenças no teor de nitrogênio das camas. Ao final dos experimentos, foi possível constatar que a maior produção de excretas pelos machos acarreta maior formação de nitrogênio. Hernandes et al. [50] indicaram que o sexo das aves não influenciou a quantidade de amônia volatilizada.

\section{Densidade populacional}

Uma criação típica de frangos aloja de 16 a 20 frangos por metro quadrado possibilitando, assim, uma melhor relação custo/benefício para o produtor [45]. Esta prática causa alterações no ecossistema de criação, interferindo no bemestar das aves, aumentando a concentração de fezes e dejeções que acarretam na maior formação de gases irritantes como a amônia [74].

\section{Tempo de criação e idade das aves}

O consumo de ração e água e o acúmulo da quantidade de excretas aumentam com o tempo de criação. A idade das aves também interfere, uma vez que o nível de proteína bruta (nitrogênio total x 6,25) na excreta aumenta com o envelhecimento das aves. Segundo Kubena et al. [75], este é um reflexo da redução da eficiência alimentar com o aumento da idade das aves, contribuindo para o aumento no teor de nitrogênio disponível na cama de frango. Redwine et al. [76] concluíram que as taxas de emissão de amônia e de material particulado aumentam com a idade das aves.

\section{Espessura da cama de frango}

A altura da cama de frango deve ser tal que proporcione o isolamento físico e térmico das aves. Recomenda-se que a altura da cama seja alterada em função da densidade de criação. A espessura recomendada pode variar de $5-10 \mathrm{~cm}$, 
dependendo ainda do material utilizado, período do ano e condições do galpão [77].

Quando diferentes quantidades de cama de frango foram incubadas (alterando-se assim a espessura da cama de frango) nos experimentos de Hernandes e Cazetta [78], houve tendência da menor quantidade de material incubado $(25 \mathrm{~g}$ ) liberar maior quantidade de amônia. Segundo os autores, a provável explicação deve-se ao fato de que, quanto menor a espessura da camada da amostra no fundo do frasco, mais fáceis são as trocas gasosas com a atmosfera interna do recipiente incubador.

\section{Grupos de microorganismos}

Dois principais grupos de microorganismos são responsáveis pela decomposição da excreta ou excremento [79]:

- Aeróbico, aqueles que necessitam de oxigênio para sobreviver.

- $\quad$ Anaeróbico, aqueles que prosperam sem oxigênio.

Os microorganismos aeróbicos usam a energia do excremento para gerar dióxido de carbono, água, calor e húmus estável. Geralmente não produzem odores desagradáveis, mas requerem um abundante suprimento de oxigênio. Entretanto, sem a incorporação proposital de ar, os microorganismos aeróbicos podem exaurir o oxigênio disponível e fazer com que partes da pilha do excremento tornem-se anaeróbicas [79].

Bactérias anaeróbicas podem utilizar a energia do excremento para gerar biogás (metano e dióxido de carbono) e um efluente liquefeito e estável. Se as condições não são apropriadas, essas bactérias podem gerar subprodutos que resultam em odores desagradáveis. As bactérias anaeróbicas sobrevivem em sistemas de excremento líquido, onde o ar não consegue infiltrar-se e em pilhas de excremento muito úmidas ou compactadas para permitir a permeação do ar [79].

Os odores desagradáveis são o resultado de uma decomposição anaeróbica incompleta, enquanto o biogás e o húmus estável são o resultado de uma decomposição anaeróbica completa [79]. 
A atividade microbial do excremento de diferentes espécies de animais é afetada pelos sólidos totais. Excrementos contendo um alto teor de sólidos, como o de frango que contém 25 por cento de sólidos totais, têm uma chance melhor de manter a atividade microbial aeróbica do que o excremento de porco que é mais de $90 \%$ de água. O excremento líquido de porco proporciona um ambiente ideal para os organismos anaeróbicos se desenvolverem [79].

A composição da alimentação também afeta a atividade microbial. Dietas ricas em proteínas incentivam condições anaeróbicas e mais odores ofensivos do que alimentos ricos em fibras. Por exemplo, o excremento de vaca é geralmente considerado uma fonte menor de odores do que os excrementos de porco ou de frango, ricos em nitrogênio. Nitrogênio e oxigênio são fatores limitantes importantes para a atividade microbial aeróbica. Quando o nitrogênio é abundante, a atividade dos microorganismos é limitada pelo suprimento de oxigênio. Em excrementos nitrogenados os microorganismos rapidamente usam o limitado suprimento de oxigênio fazendo com que o restante se torne anaeróbico. Além disso, excrementos nitrogenados podem favorecer a produção de certos compostos nitrogenados, como a amônia [79].

A amônia pode ser produzida tanto pelos microorganismos aeróbicos, quanto pelos anaeróbicos. Na TAB. 5 são apresentadas algumas características desses microorganismos e seus subprodutos do crescimento. 
TABELA 5 - Tipos, ambientes, fontes de alimento e subprodutos do crescimento dos microorganismos

\begin{tabular}{|c|c|c|c|}
\hline \multicolumn{4}{|c|}{ MICROORGANISMOS AERÓBICOS } \\
\hline Microorganismo & Ambiente & $\begin{array}{l}\text { Fonte de } \\
\text { alimento }\end{array}$ & $\begin{array}{l}\text { Subprodutos do } \\
\text { crescimento }\end{array}$ \\
\hline Bactérias aeróbicas & $\begin{array}{ll}\text { - } & \text { Oxigênio } \\
& \text { disponível } \\
\text { - } & \text { Quantidade } \\
& \text { adequada e não } \\
\text { excessiva de } \\
\text { água } \\
\text { - } \\
\text { Estreita faixa de } \\
\text { condições de pH } \\
\text { (não ácidas) }\end{array}$ & $\begin{array}{l}\text { Matéria orgânica } \\
\text { prontamente } \\
\text { disponível como } \\
\text { ácidos } \\
\text { orgânicos e } \\
\text { açúcar }\end{array}$ & $\begin{array}{l}\mathrm{CO}_{2}, \mathrm{H}_{2} \mathrm{O}, \mathrm{NH}_{3} \mathrm{e} \\
\text { húmus estável }\end{array}$ \\
\hline Actinomicetos & $\begin{array}{ll}- & \text { Ambiente seco e } \\
& \text { quente } \\
\text { - } & \text { Oxigênio } \\
& \text { disponível } \\
\text { - } & \text { pH }>5 \\
- & \text { Baixo conteúdo } \\
& \text { de nitrogênio }\end{array}$ & $\begin{array}{l}\text { Matéria orgânica } \\
\text { complexa como } \\
\text { gorduras, } \\
\text { proteínas e } \\
\text { celulose como } \\
\text { ácidos e açúcar }\end{array}$ & $\begin{array}{l}\mathrm{CO}_{2}, \mathrm{H}_{2} \mathrm{O}, \mathrm{NH}_{3} \mathrm{e} \\
\text { húmus estável }\end{array}$ \\
\hline \multicolumn{4}{|c|}{ MICROOGANISMOS ANAERÓBICOS } \\
\hline Microorganismo & Ambiente & $\begin{array}{l}\text { Fonte de } \\
\text { alimento }\end{array}$ & $\begin{array}{l}\text { Subprodutos do } \\
\text { crescimento }\end{array}$ \\
\hline $\begin{array}{l}\text { Bactérias formadoras } \\
\text { de ácido }\end{array}$ & $\begin{array}{ll}- & \text { Sem oxigênio } \\
& \text { disponível } \\
\text { - } & \text { Ampla faixa de } \\
\text { temperatura e } \\
\text { pH }\end{array}$ & $\begin{array}{l}\text { Compostos } \\
\text { orgânicos } \\
\text { complexos }\end{array}$ & $\begin{array}{l}\text { Ácidos orgânicos } \\
\text { simples } \\
\text { (freqüentemente } \\
\text { odoríferos), alcoóis, } \\
\mathrm{CO}_{2}, \mathrm{H}_{2} \mathrm{~S} \text { e húmus } \\
\text { estável }\end{array}$ \\
\hline $\begin{array}{l}\text { Bactérias } \\
\text { Metanogênicas }\end{array}$ & $\begin{array}{ll}- & \text { Sem oxigênio } \\
& \text { disponível } \\
\text { - } & \text { Temperatura } \\
& \text { controlada } \\
\text { - } & \text { pH entre } 6,2 \text { e } \\
& 7,2 \\
\end{array}$ & $\begin{array}{l}\text { Ácidos } \\
\text { orgânicos } \\
\text { simples }\end{array}$ & $\begin{array}{l}\text { Biogás }\left(\mathrm{CO}_{2}, \mathrm{CH}_{4},\right. \\
\left.\mathrm{NH}_{3}, \mathrm{H}_{2} \mathrm{~S}\right) \text { e húmus } \\
\text { estável }\end{array}$ \\
\hline
\end{tabular}

Fonte: Leggett et al. [79]. 
As condições do ambiente: presença ou não de oxigênio, $\mathrm{pH}$, temperatura, umidade e fonte de alimento podem favorecer ou não a produção de amônia como subproduto do crescimento bacteriano.

\section{Enzima Urease}

A enzima urease é produzida por um grande número de microorganismos encontrados nas excretas dos frangos. Essa enzima atua na última das cinco etapas de degradação do ácido úrico, catalisando a hidrólise da uréia em amônia e dióxido de carbono. Nas leguminosas é encontrada em grande quantidade no feijão-de-porco (Canavalia ensiformis). A urease da semente do feijão-de-porco foi a primeira enzima a ser cristalizada em 1926 [80].

\section{$\underline{\text { Temperatura }}$}

A temperatura é uma variável muito importante durante os processos de emissão de amônia da cama de frango. A temperatura do ar influencia o coeficiente da transferência convectiva de massa. A temperatura da cama pode influenciar na constante de Henry, na constante de dissociação e também na difusão e geração de amônia na cama. Dessa maneira, o fluxo de amônia pode ser muito afetado pelas mudanças de temperaturas. Nos sistemas produtivos a temperatura é regulada com freqüência, permanecendo razoavelmente uniforme para otimizar a saúde das aves e a produtividade. Em clima quente, é uma prática comum elevar a taxa de ventilação para manter a temperatura do ar desejada. A variação da temperatura ambiente requer o ajuste da taxa de troca de ar e a variação dessa taxa causa a variação dos fluxos de amônia [9].

\section{Taxa de troca de ar e velocidade}

A taxa de troca de ar influencia a concentração de amônia na corrente de ar e o coeficiente de transferência convectiva de massa, exercendo influência sobre as emissões de amônia da cama [9]. Tem sido reportado que as concentrações de amônia nos galpões são baixas quando as taxas de troca de ar (taxa de ventilação) são altas [76]. Quando a taxa de troca de ar aumenta, a concentração de amônia gasosa da corrente de ar diminui, portanto o fluxo de amônia aumenta [9]. 
Os maiores fluxos de amônia nas maiores taxas de troca de ar também podem ser devido ao maior coeficiente de transferência convectiva de massa, pois o coeficiente de transferência de massa é função da velocidade do ar na superfície da cama e pode aumentar com a taxa de troca de ar [9].

$\underline{\mathrm{pH}}$

$\mathrm{O}$ pH é influenciado pelo balanço entre ácidos voláteis e a amônia, formados durante a decomposição do excremento, o pH pode variar dependendo das práticas de manejo [79].

$\mathrm{O}$ valor do $\mathrm{pH}$ do excremento é um dos fatores mais importantes, pois determina a concentração de amônia na fase aquosa ou gasosa, influenciando a sua liberação [9]. Pesquisas têm demonstrado que a liberação de amônia da cama é insignificante quando o pH está abaixo de 7 [81]. A liberação de amônia começa quando o $\mathrm{pH}$ está próximo a 7 e aumenta significativamente acima de $\mathrm{pH}$ 8 [9]. Em pH abaixo de 7 , os íons $\mathrm{H}^{+}$na cama fazem com que se aumente a proporção amônio:amônia, ou seja, mais amônia será convertida em íon amônio que não é volátil [37].

A liberação de outros gases influencia o valor de $\mathrm{pH}$ do excremento. A liberação do $\mathrm{CO}_{2}$ eleva o $\mathrm{pH}$ e age como um fator acelerador para a liberação de amônia [59].

Teor de umidade

Quanto mais úmida a cama, mais provável a proliferação de microorganismos. A cama úmida é a primeira causa da emissão de amônia e um dos fatores ambientais e de desempenho mais sérios que afetam a produção de frango hoje em dia. Controlar a umidade da cama é a etapa mais importante para evitar problemas com a amônia [53].

Camas muito secas e empoeiradas também podem levar a problemas, como a desidratação de frangos novos, doenças respiratórias e o aumento da mortalidade. Idealmente, o teor de umidade da cama deve ser mantido entre 20 e $25 \%$. Uma regra prática para se estimar o teor de umidade é apertar um punhado de cama de frango. Se aderir firmemente e permanecer como uma bola, está 
muito úmida. Se aderir levemente, possui o teor de umidade apropriado. Se não aderir, pode estar muito seca [53].

A volatilização da amônia em camas muito úmidas é reduzida pela forte afinidade dissociativa da amônia em água [82] e pelo fato de a velocidade das atividades microbianas e enzimáticas ser reduzida ou encerrada devido à escassez de oxigênio [9]. Em camas secas a conversão da uréia em amônia pode ser reduzida e em camas de frango excessivamente secas, a maior quantidade de partículas de pó serve como um mecanismo de transporte para a amônia [9].

A umidade da cama é principalmente influenciada pelos sistemas de ventilação e bebedouros. A geometria do bebedouro das granjas pode causar 0 derramamento de água e provocar umidade excessiva [9]. Maiores teores de matéria seca e menores emissões de amônia foram medidas em granjas que utilizavam bebedouros do tipo chupeta do que aquelas que utilizavam os tradicionais bebedouros do tipo pendular [72].

\section{Reuso da cama}

A prática do reuso da cama, para ser bem sucedida, requer o controle de vários parâmetros. Os produtores precisam estar alerta às mudanças na qualidade da cama e tomar medidas para manter um ambiente interno apropriado para um desempenho favorável das aves [53].

Altos níveis de amônia podem ser observados no início da criação em galpões que reutilizam a cama [83], já que o teor de nitrogênio é maior. Isto se torna um agravante devido à alta população de aves encontradas em um sistema produtivo de frango de corte, como apresentado na FIG. 5. Foi reportado que o fluxo de amônia da cama reutilizada foi seis vezes maior do que da cama com material novo no início da engorda [84]. 


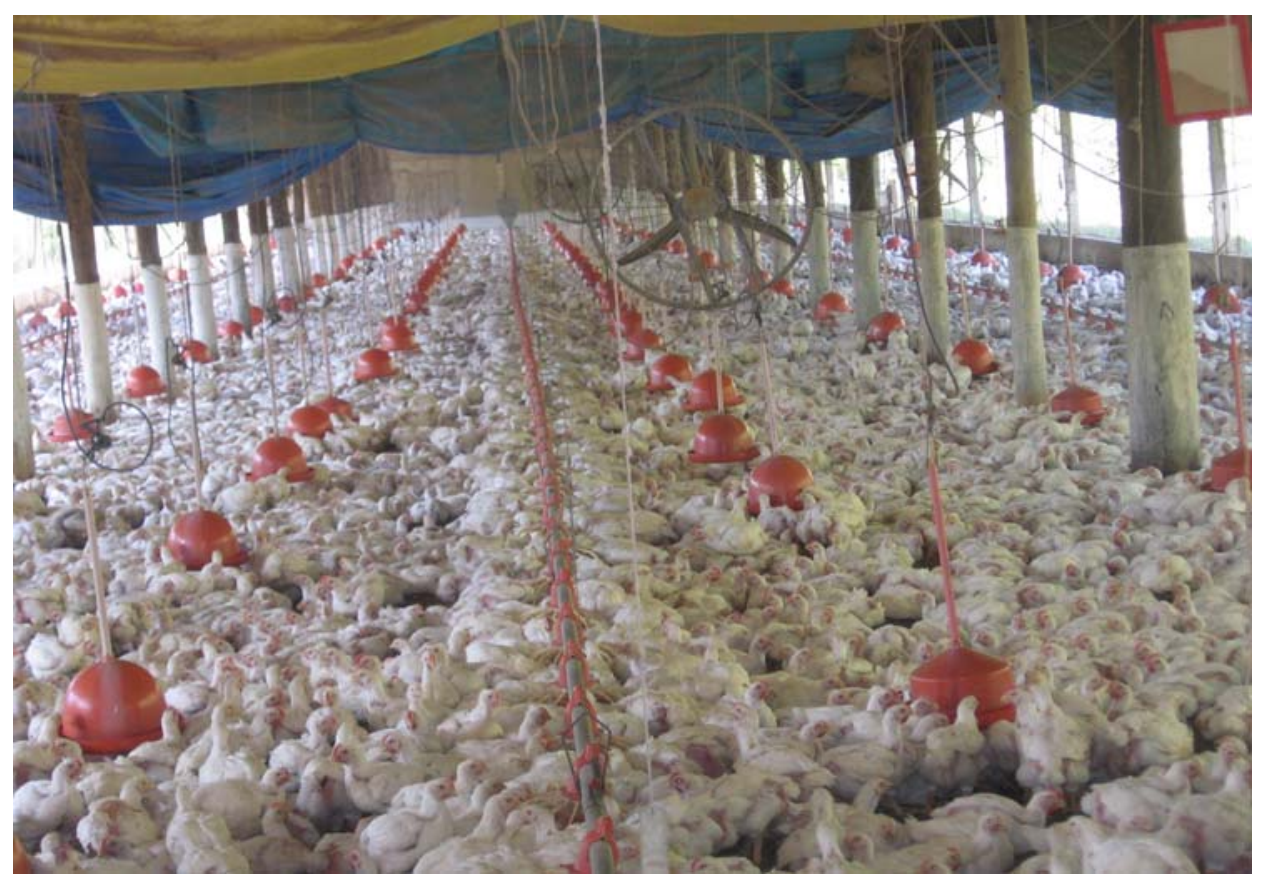

FIGURA 5 - Imagem de um sistema produtivo de frango de corte

Fonte: Arquivo pessoal, 2009.

\subsection{Danos Provocados pela amônia}

Muitos produtores subestimam os efeitos prejudiciais da amônia. O olfato humano é capaz de detectar níveis de amônia próximos a 15 partes por milhão (ppm), porém pode perder esse nível de sensibilidade em uma exposição a longo prazo [53]. Dessa forma, os trabalhadores e as aves são afetados muito antes que o problema seja percebido ou identificado.

A Agência de Proteção Ambiental dos Estados Unidos, a EPA, fixou que os padrões de exposição humana não devem exceder 25 ppm em 8 horas, ou 35 ppm em 15 minutos de exposição [53]. No Brasil a norma regulamentadora NR 15 - Atividades e Operações Insalubres regulamentam que o limite de exposição para trabalhadores é de 20 ppm de amônia em 48 horas/semana [41].

O efeito danoso sobre a saúde depende da concentração do gás e da duração à exposição [85]. No ser humano concentrações de amônia de 50 a 110 ppm podem causar ardência no olho, formação de lágrimas e induzir possíveis riscos a saúde dos trabalhadores da granja [53]. Concentrações acima de 5000 ppm são consideradas mortais [86]. 
Para os sistemas produtivos existem níveis máximos de gases permitidos. Na TAB. 6 são mostrados os níveis máximos de alguns gases segundo a UBA União Brasileira de Avicultura [87].

TABELA 6 - Níveis máximos de gases para sistemas produtivos de frangos

\begin{tabular}{cc}
\hline Gases & Nível máximo \\
\hline Amônia & $25 \mathrm{ppm}$ \\
Dióxido de Carbono & $5000 \mathrm{ppm}$ \\
Monóxido de carbono & $50 \mathrm{ppm}$ \\
Sulfeto de Hidrogênio & $10 \mathrm{ppm}$ \\
Poeira inalável & $10 \mathrm{mg} / \mathrm{m}^{3}$ \\
\hline
\end{tabular}

Fonte: UBA - União Brasileira de Avicultura, 2008 [87].

Os frangos também são sensíveis à amônia. Exposições prolongadas a níveis altos (50 a $110 \mathrm{ppm}$ ) podem resultar em keratoconjunctivitis (cegueira). Obviamente, quando o nível de amônia é alto o suficiente para cegar os frangos, a produção é seriamente afetada; entretanto, níveis de amônia de 25 ppm têm deprimido o crescimento e aumentado a taxa de conversão alimentar em frangos. Adicionalmente, uma alta incidência de aerossaculite, de infecções virais e de condenações tem sido vinculada à níveis de amônia nesta concentração. A volatilização de amônia da cama de frango pode também causar poluição atmosférica e diminuição do valor fertilizante da cama devido à perda de nitrogênio [53].

Miles et al. [88] estudaram a influência da amônia na massa corpórea das aves. As aves foram expostas às concentrações de 0, 25, 50 e $75 \mathrm{ppm}$ de amônia. A massa corpórea foi significantemente reduzida para 6 e $9 \%$ nas concentrações de 50 e 75 ppm quando comparado com 0 ppm de amônia. A mortalidade também foi significantemente maior em 75 ppm, sendo de 13,9\% e em $0 \mathrm{ppm}$ de $5,8 \%$. Os resultados desse estudo podem ser visualizados na FIG. 6. 


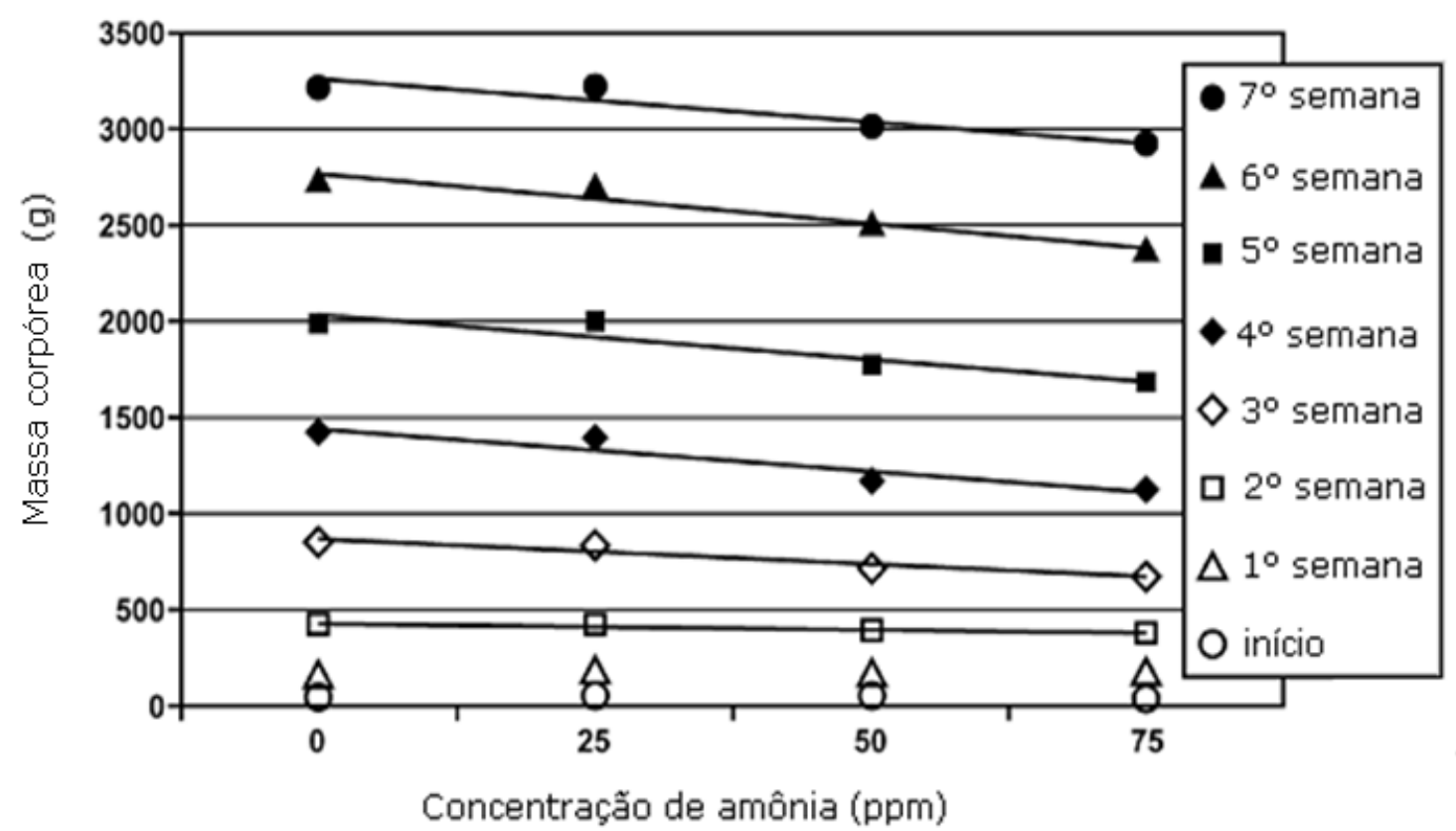

FIGURA 6 - Efeito da atmosfera da amônia na massa corpórea de frangos durante sete semanas

Fonte: Miles et al., 2004 [88].

Kristensen et al. [89] avaliaram as preferências comportamentais de aves domésticas em concentrações de amônia típicas das granjas comerciais. Os grupos de aves foram expostos à três concentrações de amônia 0,25 e 45 ppm. Nos ambientes livres de amônia o bem estar das aves foi maior do que as outras duas concentrações de amônia, sugerindo que o limite de amônia seria de 0 a 25 ppm e que concentrações superiores podem ser repugnante às aves.

\subsection{Custos associados à amônia}

Ritz et al. [53] calcularam os custos resultantes de um manejo inadequado da cama de frango em sistemas produtivos de frango de corte. Todos os custos foram mantidos em dólar para terem-se elementos de comparação com os prejuízos causados por um ambiente com alta concentração de amônia (maior do que 50 ppm).

Obviamente, esses custos são aproximações grosseiras, mas foram feitas de maneira conservativa de modo a evitar uma avaliação excessiva. Esses valores podem ser verificados na TAB. 7 [53]. 
TABELA 7 - Custo estimado associado às condições inadequadas da cama para 20.000 aves

\begin{tabular}{|c|c|}
\hline $\begin{array}{c}\text { Fator e } \\
\text { Custo }\end{array}$ & Análise Racional \\
\hline $\begin{array}{l}\text { Amônia } \\
\text { (US\$ 430) }\end{array}$ & $\begin{array}{l}\text { Quando as condições da cama deterioram, a amônia sempre é um } \\
\text { problema. Pesquisas mostraram que ao atingir níveis de amônia de } 50 \\
\text { ppm ou maiores, as taxas de conversão alimentar podem ser } \\
\text { aumentadas em até } 8 \% \text { e o ganho de peso pode diminuir em cerca de } \\
0,11 \mathrm{~kg}\end{array}$ \\
\hline $\begin{array}{l}\text { Doenças } \\
\text { (US\$ 120) }\end{array}$ & $\begin{array}{l}\text { É estimado que o custo para as aviculturas dos Estados Unidos da } \\
\text { América é de US } \$ 500 \text { milhões por ano em mortalidade, morbidez e } \\
\text { medicação. Uma estimativa conservadora seria que as condições da } \\
\text { cama são responsáveis por } 10 \% \text { dessas perdas }\end{array}$ \\
\hline $\begin{array}{l}\text { Parasitas } \\
\text { (US\$ 140) }\end{array}$ & $\begin{array}{l}\text { Drogas anticoccidial custam aos produtores americanos US } \$ 125 \\
\text { milhões/ano e os anti-helmínticos custam outros US } \$ 35 \text { milhões. } \\
\text { Considerando que a carga de parasitas na cama de frango reutilizada } \\
\text { pode aumentar a probabilidade de infecções e que a cama úmida } \\
\text { promove a esporulação de oocistos, o custo é considerável }\end{array}$ \\
\hline $\begin{array}{l}\text { Mortalidade } \\
\text { e qualidade } \\
\text { (US\$260) }\end{array}$ & $\begin{array}{l}\text { Estudos têm reportado que as condições da cama de frango afetam } \\
\text { significativamente a mortalidade e a qualidade final do frango criado }\end{array}$ \\
\hline $\begin{array}{l}\text { Total } \\
\text { (US\$ 950) }\end{array}$ & $\begin{array}{l}\text { Somando-se as perdas as condições inadequadas da cama de frango } \\
\text { custam aos produtores pelo menos US } \$ 950 \text { na produção de } 20.000 \\
\text { frangos. Essa é uma estimativa conservadora, as perdas reais podem } \\
\text { ser muito maiores }\end{array}$ \\
\hline
\end{tabular}

Fonte: Ritz et al., 2005 [53]. 
Somente o cálculo para o custo da amônia foi descrito e pode ser visualizado a seguir [53].

Cálculo do impacto da amônia na conversão alimentar - o aumento no índice de conversão alimentar indica que mais ração foi consumida para que existisse o ganho de massa corpóreo pela ave:

20.000 aves multiplicado por 2,26 kg (peso vivo do frango); multiplicado por 0,08 (aumento de $8 \%$ no índice de conversão alimentar); multiplicado por US\$160/ton (custo da ração) totalizando US\$560

Cálculo do impacto da amônia na redução do ganho de massa corpórea prejuízo para o produtor pela menor produção de carne de frango:

20.000 aves multiplicado por $0,11 \mathrm{~kg}$ (perda de peso por ave); multiplicado por US\$ 0,06 (Prejuízo) totalizando US\$ 300

Para um total de 20.000 aves a soma das perdas podem atingir valores de até US $\$ 860$, porém para ser conservativo, os autores utilizaram $50 \%$ do total (US\$ 430).

\subsection{Matéria orgânica e energia}

A utilização da energia contida na matéria orgânica é uma excelente maneira de aproveitar e fazer uso das etapas do fluxo de energia para geração de eletricidade.

Neste fluxo, a energia proveniente do sol é armazenada nas plantas, que a utilizam em seu metabolismo e na realização da fotossíntese. Essa energia, agora química, será consumida por algum animal que a converterá em massa corpórea. Contudo, nem toda energia que é assimilada permanece no fluxo, parte dela é utilizada em processos vitais e também perdida pela transpiração. A parte da alimentação animal que não é utilizada, ou seja, é excretada, contém uma parcela menor da energia que entrou no fluxo e os microorganismos presentes na matéria orgânica excretada sobrevivem desta parcela [79].

Nessa matéria orgânica encontra-se o nitrogênio, um constituinte necessário para o crescimento de organismos vivos. Esse elemento é um dos constituintes da atmosfera que, apesar de abundante, não pode ser absorvido 
diretamente pelas plantas e animais. As bactérias são capazes de fixar o nitrogênio no solo e assim as plantas são capazes de absorvê-lo. Denomina-se "ciclo do nitrogênio" à circulação desse elemento na natureza [24, 35]. nitrogênio consumido na alimentação é metabolizado pelas aves e a parte restante é excretada como ácido úrico.

Além do nitrogênio, outros nutrientes estão presentes nos excrementos, como por exemplo, o fósforo e o potássio, os quais são importantes para o crescimento da plantação, mas quando em excesso não são totalmente absorvidos. Existe um limite para a quantidade que pode ser aplicada por hectare, dependendo da cultura, tipo de solo e drenagem [90]. Os nutrientes não absorvidos pelas plantas podem ser carregados pela água ou infiltrar-se no solo. A eutrofização da água favorece o crescimento de algas que consomem o oxigênio comprometendo outros organismos que habitam o mesmo ambiente.

Como o meio ambiente não é capaz de receber toda a carga de resíduos gerados, alternativas para o reaproveitamento são necessárias. Uma delas é o tratamento dos dejetos pela técnica de manipulação mais conhecida, a biodigestão anaeróbica [91, 92]. Na biodigestão, de diferentes excrementos, ocorre a produção majoritária do gás metano, seguido de monóxido de carbono, sulfeto de hidrogênio e amônia [8]. O biogás também pode ser utilizado na obtenção de hidrogênio por meio de decomposição catalítica [3, 18].

Especificamente para os dejetos de galináceas, da decomposição do ácido úrico advêm o subproduto de interesse, a amônia. A escolha do aproveitamento da amônia proveniente dos dejetos surge como uma nova opção quando se fala sobre fontes renováveis para a obtenção de hidrogênio.

No presente trabalho estudaram-se os parâmetros que aceleram a volatilização da amônia gerada nos resíduos de criação de frangos visando o aproveitamento energético dos dejetos. Esse processo só é possível, pois a energia do sol foi absorvida pelo milho, ou outros vegetais, que são fontes de alimento para as galinhas e frangos que fazem uso dessa energia e excretam parte dela. A FIG. 7 ilustra um fluxo de energia em uma operação de criação animal, as setas brancas denotam a transferência de energia. 


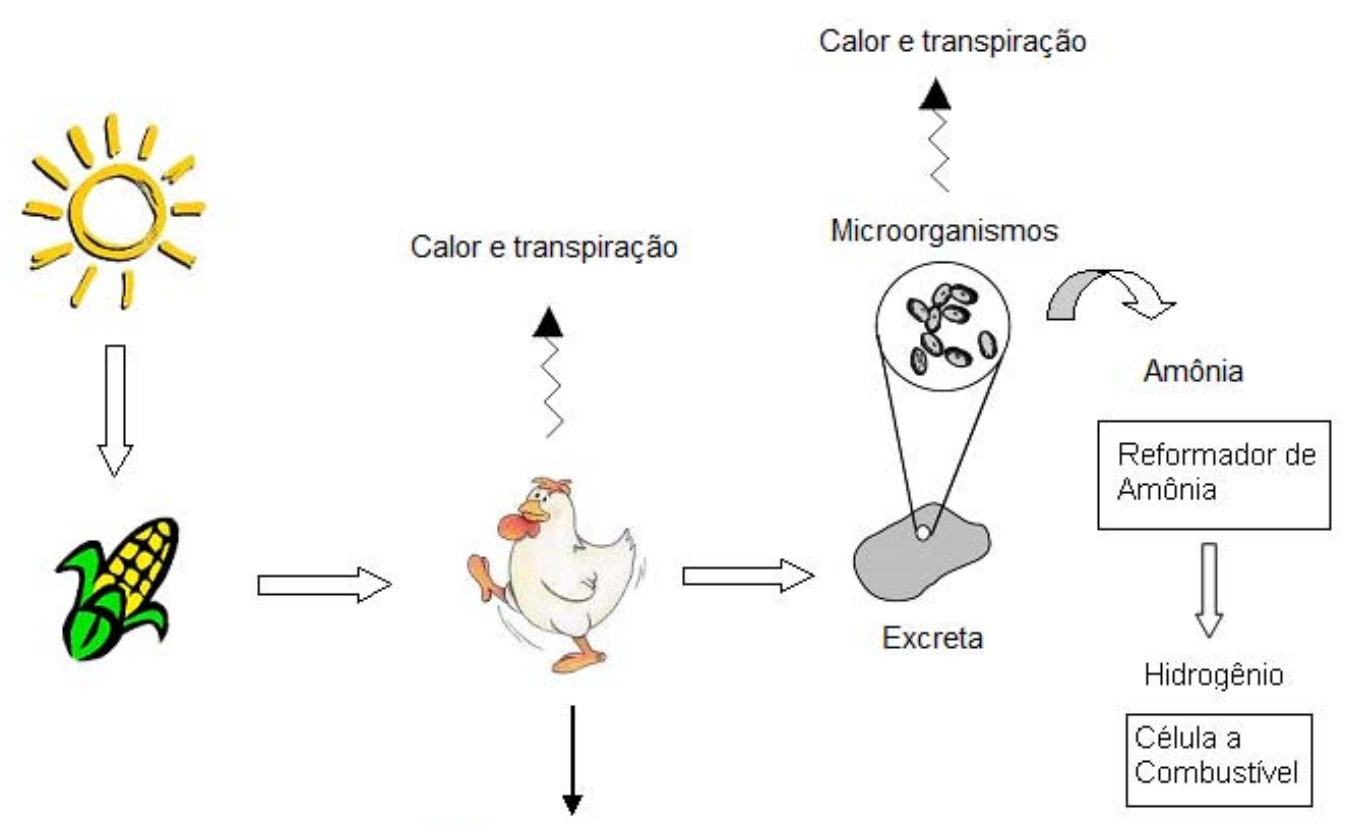

Produtos animais

FIGURA 7 - Fluxo de energia em uma operação de criação animal no qual as setas brancas denotam a transferência de energia

Adaptado de Leggett et al. [79].

A escolha do tema desse trabalho está relacionada ao fluxo de energia e busca destinação ao resíduo e à amônia proveniente deste. Adicionalmente, a oportunidade de produção de energia elétrica poderá auxiliar no suprimento da demanda por energia atendendo, assim, a questões ambientais, energéticas e econômicas. 


\section{MATERIAIS E MÉTODOS}

Os experimentos foram conduzidos no Laboratório de Produção de Hidrogênio do Centro de Células a Combustível e Hidrogênio - $\mathrm{CCCH}$ do Instituto de Pesquisas Energéticas e Nucleares, IPEN - Comissão Nacional de Energia Nuclear - CNEN/SP. Dois tipos de materiais foram testados para avaliação das emissões de amônia, a cama de frango e a excreta de galinhas poedeiras. A cama de frango utilizada nos experimentos foi coletada em uma granja localizada no município de Bragança Paulista no estado de São Paulo em diferentes períodos de criação. As excretas foram coletadas na Faculdade de Medicina Veterinária e Zootecnia da Universidade de São Paulo - FMVZ-USP, Departamento de Clínica Médica.

A metodologia para determinar a amônia liberada, exceto em um experimento, foi uma adaptação do método utilizado por Hernandes e Cazetta [78]. Frascos com diferentes capacidades foram utilizados como câmaras incubadoras. Como solução fixadora de amônia foram utilizados $25 \mathrm{~mL}$ de ácido bórico $0,3 \mathrm{~mol} . \mathrm{L}^{-1}$, contido em frascos tipo béquer com capacidade de $100 \mathrm{~mL}$. A determinação da quantidade de amônia (mol. $\mathrm{L}^{-1}$ ) fixada na solução de ácido bórico foi realizada por titulação. Uma solução padrão de hidróxido de sódio $\mathrm{NaOH}$, foi utilizada na titulação da solução fixadora de amônia quando havia excesso de ácido, ou seja, a solução de ácido bórico não tinha sido totalmente neutralizada pela amônia. Já a solução padrão de ácido sulfúrico $-\mathrm{H}_{2} \mathrm{SO}_{4}$, foi utilizada na titulação da solução fixadora de amônia, quando havia um excesso de base, ou seja a solução de ácido bórico foi neutralizada pela amônia fixada e havia ainda um excesso. Como indicador foi utilizado fenolftaleína.

\subsection{Caracterização das amostras}

A caracterização das amostras foi realizada por meio das técnicas de Espectrometria de Fluorescência de Raios-X por Dispersão de Comprimento de Onda (WDXRF), Análise Elementar carbono hidrogênio e nitrogênio - $\mathrm{CHN}$, Termogravimetria e Cromatografia a gás acoplada à Espectrometria de massa GC/MS - Gas chromatography / Mass spectrometry. O teor de voláteis, de perda ao fogo e $\mathrm{pH}$ também foram determinados. 


\subsubsection{Espectrometria de Fluorescência de Raios-X por Dispersão de Comprimento de Onda (WDXRF)}

Amostras sem umidade da cama de frango e da excreta foram compactadas, obtendo-se uma pastilha prensada de $20 \mathrm{~mm}$ de diâmetro. As pastilhas foram analisadas no espectrômetro de fluorescência de raios- $X$ com dispersão de comprimento de onda (WDXRF), modelo RIX-3000 da Rigaku Co. Ltd, 1996.

\subsubsection{Análise Elementar CHN}

Para a análise elementar, amostras de 2-3 $\mathrm{mg}$ de cama de frango e excreta, com e sem umidade, foram pesadas em triplicata em balança marca Sartorius, modelo MC210 S com precisão de $0,00001 \mathrm{~g}$. A análise elementar foi realizada em aparelho Perkin Elmer Elemental Analyser $2400 \mathrm{CHN}$.

\subsubsection{Termogravimetria}

A Termogravimetria (TG), a Termogravimetria Derivada (DTG) e a Análise Térmica Diferencial (DTA) das amostras de cama de frango e excreta foram realizadas para caracterizar a decomposição térmica do material, teor de voláteis e o teor de cinzas.

A degradação térmica das amostras foi conduzida em um módulo termogravimétrico com razão de aquecimento de $5^{\circ} \mathrm{C} \mathrm{min}^{-1}$, em atmosfera dinâmica de ar sintético com vazão de $50 \mathrm{~mL} \cdot \mathrm{min}^{-1}$, sob pressão atmosférica. A temperatura máxima empregada foi de aproximadamente $1000^{\circ} \mathrm{C}$, em cadinho de alumina. $O$ equipamento utilizado foi da marca Setaram Labsys.

Os dois materiais, cama de frango e excreta, são heterogêneos e geralmente apresentam penas e restos de alimentos. Esses materiais foram acondicionados em frascos de vidro $\mathrm{e}$ as amostras foram retiradas randomicamente.

Na FMVZ-USP as aves são alimentadas com dois tipos de ração, uma comercial e outra preparada para fins de pesquisa. Somente a excreta, 
proveniente das aves alimentadas com a ração comercial foi coletada, e analisada no mesmo dia. A cama de frango foi coletada ao final de 45 dias de criação e armazenada. A granja produtora de frango de corte encerrou as atividades depois desse último lote, não sendo mais possível a coleta deste material.

Inicialmente, as curvas TG foram realizadas com as amostras da cama de frango e excreta no intervalo de temperatura entre $30^{\circ} \mathrm{C}$ e $500^{\circ} \mathrm{C}$. As curvas termogravimétricas indicaram que a perda de massa poderia continuar após essa temperatura.

Após esses ensaios exploratórios, as curvas TG foram obtidas em intervalos de temperatura que iam até $1000^{\circ} \mathrm{C}$. Nesses casos a massa inicial da amostra de cama de frango foi $34,5 \mathrm{mg}$ e a massa inicial da amostra de excreta foi de 9,9 mg. Para a realização das curvas TG somente a excreta pôde ser coletada novamente. A mesma amostra de cama de frango foi analisada, um mês depois, pela impossibilidade de nova coleta.

\subsubsection{Cromatografia a gás acoplada à Espectrometria de massa GC/MS}

As análises dos compostos orgânicos presentes nas amostras de cama de frango e excreta foram realizadas em um Cromatógrafo a gás acoplado à Espectrometria de massas GC/MS marca Shimadzu, modelo GCMS - QP5000. O volume de $10 \mu \mathrm{L}$ do analito foi introduzido no injetor do GC por uma micro-seringa graduada. A temperatura do injetor é de $230^{\circ} \mathrm{C}$ e a amostra vaporizada é introduzida na coluna cromatográfica. A coluna capilar utilizada foi a DB-5 de 30 $\mathrm{m} \times 0,25 \mathrm{~mm} \times 0,25 \mu \mathrm{m}$ e sua fase estacionária foi composta de poli-dimetilsiloxana com $5 \%$ fenila, portanto, levemente polar.

Amostras de cama de frango e de excreta com e sem umidade foram agitadas por duas horas com o solvente diclorometano para realizar a extração dos compostos. Para as amostras com umidade a quantidade de $1 \mathrm{~g}$ de material foi agitada com $10 \mathrm{~mL}$ de diclorometano e para as amostras sem umidade $2 \mathrm{~g}$ de material foram agitados com $10 \mathrm{~mL}$ do solvente. As amostras foram filtradas com papel filtro Whatman $11,0 \mathrm{~cm}$ ashless $\mathrm{n}^{\circ} 40$ e mantidas sob refrigeração até o momento da análise. 


\subsubsection{Teor de voláteis}

$\mathrm{Na}$ determinação do teor de voláteis as amostras foram submetidas a processo de secagem em temperatura de $105 \pm 5^{\circ} \mathrm{C}$ por uma hora, colocada em dessecador para esfriar e pesadas em balança com precisão de $1 \mathrm{mg}$, marca Quimis, modelo Q500L210C. Esse processo foi repetido até a estabilização da massa. Uma vez estabilizada a massa da amostra, o teor de voláteis foi determinado subtraindo-se o peso final do inicial da amostra [93].

\subsubsection{Perda ao fogo}

A perda ao fogo foi determinada em amostras in natura de $1 \mathrm{~g}$, pesadas em cadinho de porcelana tarado e levado ao forno tipo mufla à temperatura de $900^{\circ} \mathrm{C}$ por uma hora.

\subsection{7 $\mathrm{pH}$}

$\mathrm{O} \mathrm{pH}$ foi determinado utilizando-se $10 \mathrm{~g}$ de amostra de cama de frango ou de excreta em $25 \mathrm{~mL}$ de água destilada, respeitando-se a relação [1:2,5] com agitação, repouso por uma hora e leitura em pHmetro digital marca Hanna.

\subsection{Desenvolvimento Experimental}

\subsubsection{Ensaios exploratórios}

Os primeiros experimentos foram realizados em dessecador contendo $400 \mathrm{~g}$ de cama de frango na base. Para a fixação da amônia volatilizada da cama de frango utilizaram-se recipientes contendo água e/ou resina absorvedora de amônia sobre o disco de porcelana. Os dessecadores foram fechados e após alguns dias de incubação realizaram-se testes para verificar a fixação de amônia. 


\subsection{Estudo dos fatores que influenciam a volatilização da amônia}

\subsubsection{Experimentos com a cama de frango}

\subsubsection{Influência do pH - concentração de carbonato de sódio}

Diferentes aditivos químicos têm sido estudados objetivando minimizar as altas concentrações de amônia observadas na reutilização da cama de frango [37], entre eles o carbonato de sódio, o qual foi estudado por Medeiros et al. [82].

Os primeiros experimentos utilizando o carbonato de sódio como aditivo foram realizados com as concentrações de $1,3,5,7$ e $9 \%$. O tempo de confinamento dos animais foi de 20 dias no primeiro ciclo de criação e a cama de frango composta por maravalha de madeira. Frascos de vidro com capacidade de $1000 \mathrm{~mL}$ foram utilizados como câmaras incubadoras. O período de incubação foi de 24 horas. A determinação da quantidade de amônia (mol. $\mathrm{L}^{-1}$ ) fixada na solução de ácido bórico foi realizada por titulação com solução padrão de $\mathrm{NaOH}$, para as três primeiras concentrações e com solução padrão de $\mathrm{H}_{2} \mathrm{SO}_{4}$, para as duas últimas concentrações.

Como no primeiro ensaio a melhor concentração de carbonato de sódio encontrada foi a de $9 \%$, em outro experimento foi estudada uma faixa maior de concentração de carbonato $(9,19,29,39$ e 49\%). Frascos com capacidade de 1,3 $L$ foram utilizados para incubar a quantidade de 100 gramas de cama de frango. O tempo de confinamento dos animais foi de 34 dias no primeiro ciclo de criação. A primeira leitura foi de 24 horas, realizando-se a titulação do excesso de amônia, contida na solução inicial de ácido bórico dos frascos, com solução padrão de ácido sulfúrico. As soluções de ácido bórico foram trocadas e a segunda leitura foi realizada no décimo segundo dia de incubação.

\subsubsection{Influência do volume do frasco}

A mesma quantidade de cama de frango foi acondicionada em frascos com diferentes capacidades, o primeiro de 1,3 L (diâmetro de $10 \mathrm{~cm}$ e altura de 16,5 $\mathrm{cm}$ ) e o segundo de 2,0 L (diâmetro de $11 \mathrm{~cm}$ e altura de 20,5 cm). O tempo de 
confinamento dos animais foi de 34 dias no primeiro ciclo de criação. À quantidade de $100 \mathrm{~g}$ de cama de frango foram adicionadas nove gramas de carbonato de sódio obtendo-se a concentração de $9 \%$. O tempo de incubação foi de 13 dias.

\subsubsection{Influência da quantidade de cama de frango}

Mantendo-se os frascos com capacidade de 1,3 L, diferentes quantidades de cama de frango foram pesadas e adicionadas aos frascos. O tempo de confinamento dos animais foi de 46 dias no primeiro ciclo de criação. A concentração de $9 \%$ de carbonato de sódio foi escolhida para esse experimento. Assim, foram adicionados 2,25 g de carbonato de sódio a $25 \mathrm{~g}$ de cama de frango, 4,5 $\mathrm{g}$ do carbonato a $50 \mathrm{~g}$ de cama, 6,75 $\mathrm{g}$ do carbonato a $75 \mathrm{~g}$ de cama e $9 \mathrm{~g}$ do carbonato a $100 \mathrm{~g}$ de cama. O tempo de incubação foi de 19 dias.

\subsubsection{Influência da adição de água}

Diferentes volumes de água destilada (10, 20, 30 e $40 \mathrm{~mL})$ foram adicionados a $100 \mathrm{~g}$ de cama de frango, em frascos com capacidade de 1,3 L. O tempo de confinamento dos animais foi de 46 dias no primeiro ciclo de criação. Por mostrar-se adequada nos experimentos anteriores, a concentração de $30 \%$ de carbonato de sódio foi estabelecida para esse experimento. O tempo de incubação foi de 19 dias.

\subsubsection{Experimentos com a excreta}

O material utilizado nesses experimentos foi somente a excreta de galinha sem o substrato (maravalha de madeira) utilizado como piso nos sistemas produtivos de frango de corte. Na Faculdade de Medicina Veterinária e Zootecnia da Universidade de São Paulo - FMVZ-USP, Departamento de Clínica Médica, são realizados experimentos para melhorar a qualidade dos ovos. As galinhas poedeiras são confinadas em gaiolas elevadas em relação ao solo. São geralmente duas aves por gaiola e as excretas caem diretamente no chão, não havendo contato do animal com a excreta. A limpeza do local é realizada 
semanalmente pelos técnicos do biotério. A coleta da excreta foi realizada preferencialmente no sétimo dia devido ao maior acúmulo de resíduos até esse dia.

\subsubsection{Influência do pH - concentração de carbonato de sódio}

Diferentes quantidades de carbonato de sódio foram adicionadas à excreta de galinhas poedeiras de forma a obterem-se concentrações de até $30 \%$ de carbonato de sódio. A coleta da excreta foi realizada no sexto dia de acúmulo no biotério da FMVZ-USP. A metodologia para determinar a amônia liberada da excreta foi a mesma empregada nos experimentos com a cama de frango. As leituras foram efetuadas após incubação por 24, 48 e 72 horas.

\subsubsection{Influência do volume do frasco}

A mesma quantidade de excreta, $100 \mathrm{~g}$, foi acondicionada em frascos com diferentes capacidades, o primeiro de 1,3 L e o segundo de 2,0 L. A coleta da excreta foi realizada no segundo dia de acúmulo, devido à limpeza antecipada do biotério. À quantidade de $100 \mathrm{~g}$ de excreta foram adicionados $9 \mathrm{~g}$ de carbonato de sódio, obtendo-se a concentração de $9 \%$ de carbonato. As leituras foram efetuadas após incubação por 24, 48 e 72 horas.

\subsubsection{Influência da quantidade de excreta}

Diferentes quantidades de excreta foram pesadas e adicionadas aos frascos com capacidade de 1,3 L. A coleta da excreta foi realizada no segundo dia de acúmulo, devido à limpeza antecipada do biotério. Calcularam-se as quantidades de carbonato de sódio necessárias para que ao final as quantidades de $25,50,75$ e $100 \mathrm{~g}$ de excreta tivessem a concentração de $9 \%$ de carbonato de sódio. As leituras foram efetuadas após incubação por 24, 48 e 72 horas.

\subsubsection{Influência do tempo de acúmulo de resíduos}

As coletas de excreta foram realizadas em diferentes datas. Deste modo foi possível comparar os resultados dos experimentos realizados com o material 
coletado no segundo e no sexto dia de acúmulo. As condições de teste foram iguais, os frascos de capacidade de 1,3 L, a quantidade de $100 \mathrm{~g}$ de excreta e a concentração de $9 \%$ de carbonato de sódio. As leituras foram efetuadas após incubação por 24, 48 e 72 horas.

\subsubsection{Influência da areia}

Foram realizados experimentos com areia, pois segundo a USEPA Agência de Proteção Ambiental dos Estados Unidos, as perdas de amônia são maiores em níveis elevados de $\mathrm{pH}$, temperaturas elevadas, condições secas e em solos com baixa capacidade de troca iônica como a areia [94].

Um ensaio foi realizado visando avaliar a interferência da areia na volatilização da amônia. A coleta da excreta foi realizada no sétimo dia de acúmulo. À quantidade de $100 \mathrm{~g}$ de excreta foram adicionados $10,20,30$ e $40 \mathrm{~g}$ de areia. A areia de construção foi peneirada com peneira de $350 \mathrm{~mm}$, secada em estufa por 12 horas e novamente peneirada. O tempo de incubação foi de 7 dias.

Neste ensaio as tampas dos frascos de capacidade de 1,3 $L$ foram furadas para acoplar torneiras de teflon, permitindo assim a retirada do gás gerado para análise com um kit comercial.

Um kit analisador do nível de amônia em aviários, da Alfakit, foi utilizado neste ensaio. A determinação foi colorimétrica utilizando-se um sistema de comparação visual com cartela de cores, com faixa entre 15 e 1310 ppm por volume de gás amostrado, sendo uma adaptação do Standard Methods for the Examination of Water and Wastewater; $21^{\circ}$ ed., ano 2005 . A determinação da amônia foi realizada pelo método "Azul de Indofenol", número 4500 F.4-114. Os resultados indicados na cartela foram calculados em base úmida, a $25^{\circ} \mathrm{C}$ e $1 \mathrm{~atm}$ de pressão.

Uma seringa contendo solução ácida para reter amônia foi acoplada a mangueira superior da torneira da tampa do frasco. A torneira de vidro foi aberta e uma alíquota de $50 \mathrm{~mL}$ de gás foi aspirada. A solução, com a amostra de ar aspirado, foi agitada por aproximadamente 1 minuto e então transferida para uma cubeta de vidro na qual os reagentes foram adicionados. O tempo de reação 
aguardado foi de 10 minutos. A cubeta de vidro foi posicionada sobre a cartela colorimétrica e as intensidades de cores desenvolvidas foram comparadas com as cores da cartela. Determinou-se, assim, a concentração de amônia na atmosfera do interior dos frascos em ppm de $\mathrm{NH}_{3}$.

\subsubsection{Influência dos tipos de ração}

Para a alimentação das galinhas poedeiras do biotério da veterinária são oferecidos dois tipos de ração, uma comercial e outra com um maior teor de proteínas. Os experimentos foram conduzidos para avaliar a volatilização da amônia em relação às diferentes rações utilizadas na alimentação das aves. Com isso, a quantidade de amônia volatilizada pode ser relacionada com a quantidade de nitrogênio presente na alimentação.

A coleta da excreta foi realizada no sexto dia de acúmulo no biotério da FMVZ/USP. O teor de proteína bruta da ração comercial é $17,00 \%$ e o da ração em teste é 18,09\%. Dividindo-se o valor do teor de proteína bruta por 6,25 (o teor de proteína bruta é igual ao nitrogênio total x 6,25$)$, os valores de $2,72 \%$ de nitrogênio para a ração comercial e 2,89\% de nitrogênio para a ração teste foram obtidos. O tempo de incubação foi de 8 dias e o excesso de amônia, contido na solução fixadora de ácido bórico, foi titulado com solução padrão de ácido sulfúrico.

\subsubsection{Investigação da ação da enzima urease do feijão-de-porco}

A enzima urease atua na última das cinco etapas de degradação do ácido úrico, catalisando a hidrólise da uréia em amônia e dióxido de carbono. Nas leguminosas é encontrada em grande quantidade, especialmente no feijão-deporco (Canavalia ensiformis).

Para verificar a influência da enzima urease na emissão de amônia utilizouse o feijão-de-porco como fonte dessa enzima. 


\subsubsection{Extração da enzima urease}

Com o intuito de verificar o melhor procedimento para a extração da enzima urease duas metodologias foram empregadas.

$\mathrm{Na}$ primeira, $250 \mathrm{~g}$ de grãos de feijão-de-porco foram triturados em liquidificador antes da adição de água. A esse triturado adicionaram-se $1000 \mathrm{~mL}$ de água destilada. $O$ feijão permaneceu em água durante 24 horas.

$\mathrm{Na}$ segunda, à quantidade de $250 \mathrm{~g}$ de grãos inteiros de feijão-de-porco adicionaram-se $1000 \mathrm{~mL}$ de água destilada, na qual permaneceram durante 24 horas.

As diferentes metodologias empregadas para a extração da enzima urease podem ser visualizadas na FIG. 8.

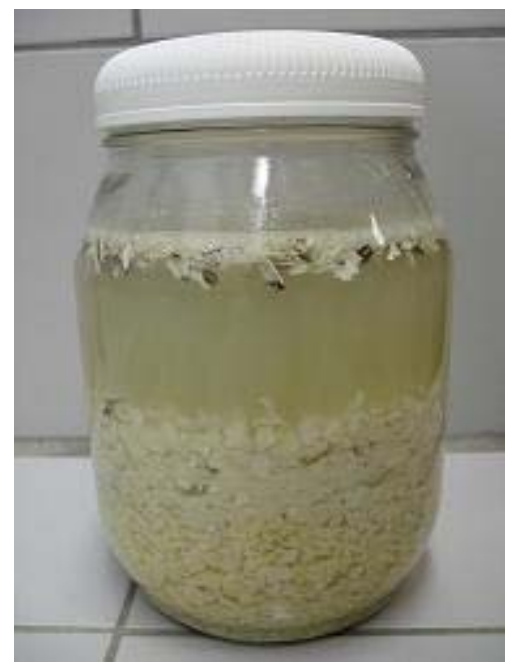

(a)

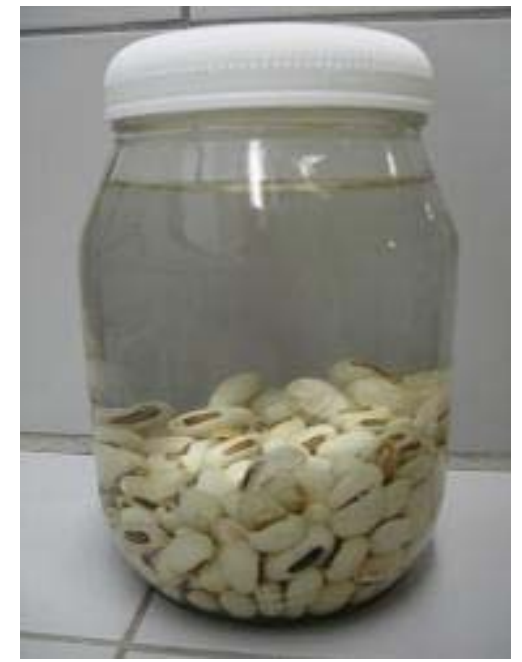

(b)

FIGURA 8 - Primeira metodologia (a) e segunda metodologia (b) para a extração da enzima urease

No dia seguinte foi constatado o aumento de tamanho do feijão triturado e do grão inteiro devido à absorção de água (FIG. 9). 


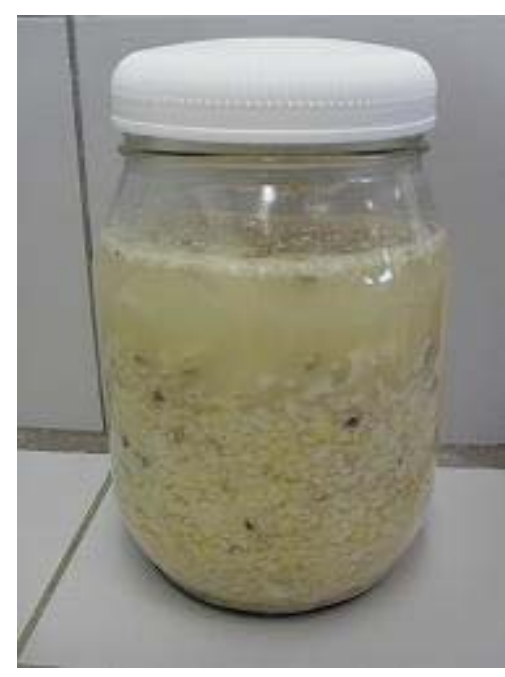

(a)

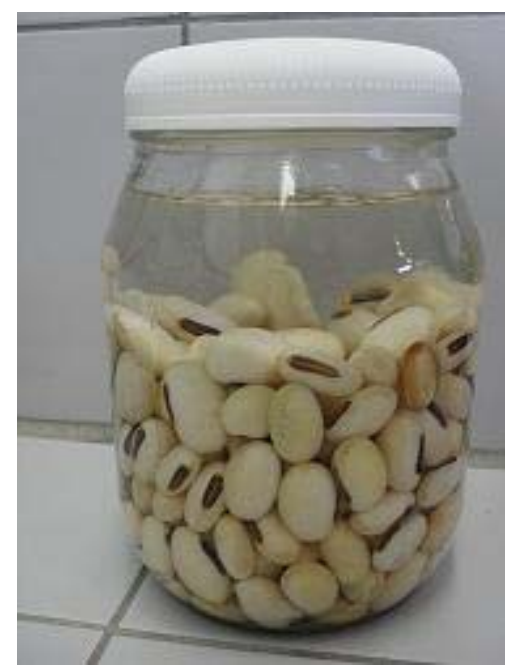

(b)

FIGURA 9 - Aumento de tamanho do feijão-de-porco, triturado (a) e grão (b), devido à absorção de água

A FIG. 10 permite a visualização do aumento do tamanho do grão após permanecer 24 horas em água.

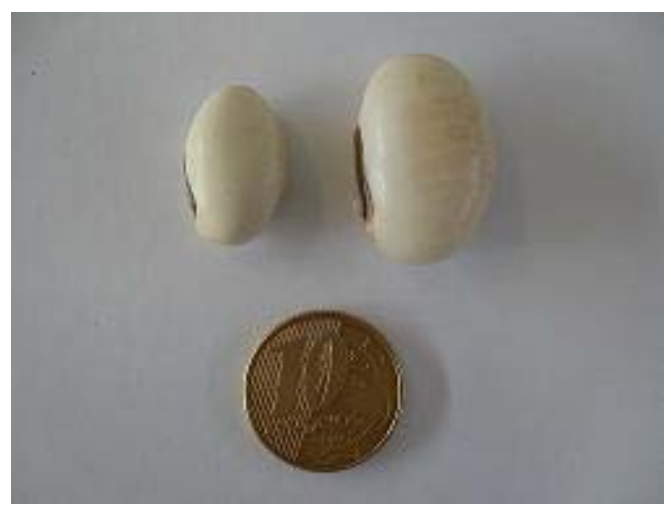

FIGURA 10 - Grão de feijão-de-porco da esquerda em tamanho normal e grão de feijão-de-porco da direita após 24 horas em água destilada

Para retirar o extrato do feijão-de-porco, tanto do grão triturado como do inteiro, o feijão foi batido em liquidificador com a água em que permaneceu até a obtenção de uma massa homogênea. Essa massa foi filtrada a vácuo para a extração de um líquido contendo a enzima urease (FIG. 11). O líquido recolhido no kitassato foi denominado extrato de feijão-de-porco. 


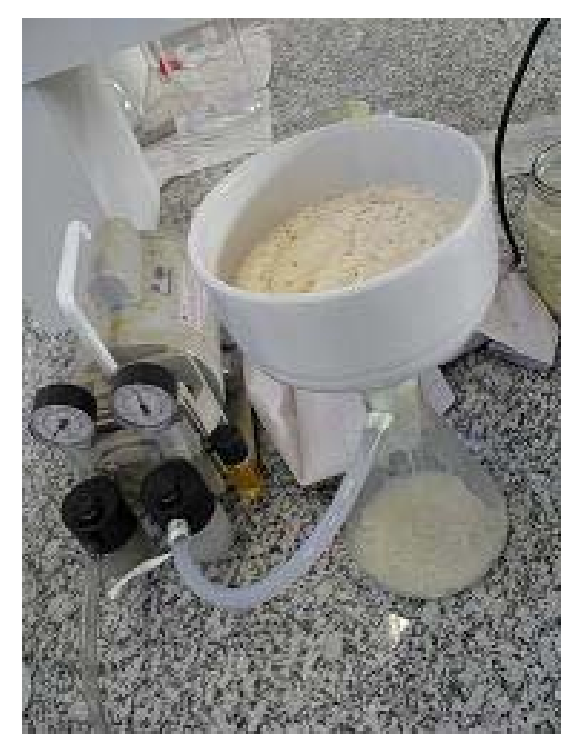

FIGURA 11 - Filtragem a vácuo do feijão-de-porco triturado para a retirada do extrato contendo a enzima urease

O resíduo obtido deste processo foi o feijão triturado com pouca umidade. Para verificar se esse resíduo, após a filtração, ainda apresentava a enzima urease foi realizado um ensaio no qual o feijão-de-porco resultante foi adicionado à excreta.

\subsubsection{Confirmação da presença da enzima urease}

Para verificar a presença da enzima urease no extrato de feijão-de-porco e sua ação na hidrólise da uréia, uma solução de uréia $(2$ g de uréia em 20 mL de água destilada) foi preparada e à essa solução foi adicionado o extrato de feijãoporco. O valor de $\mathrm{pH}$ foi verificado por meio de papel indicador universal de $\mathrm{pH}$ da Merck.

\subsubsection{Solução de uréia e extrato de feijão-de-porco}

No intuito de verificar a volatilização ou não da amônia formada na hidrólise da uréia, pela urease, foi empregada a mesma metodologia para determinação da amônia proveniente da excreta. Em um frasco com capacidade de 1,3 L adicionaram-se $50 \mathrm{~mL}$ de solução de uréia 10\% (2 g de uréia em $20 \mathrm{~mL}$ de água destilada) e $50 \mathrm{~mL}$ de extrato de feijão-de-porco. Como solução fixadora de 
amônia foram adicionados $25 \mathrm{~mL}$ de solução de ácido bórico em um bécker de $100 \mathrm{~mL}$ situado no centro do frasco.

\subsubsection{Experimentos com o extrato e o triturado do feijão-de-porco}

A excreta foi coletada no sétimo dia de acúmulo e os animais foram alimentados com ração contendo maior teor de proteínas.

À quantidade de $100 \mathrm{~g}$ de excreta foram adicionados os volumes de 25,50 , 75, 100, 150 e $200 \mathrm{~mL}$ do extrato de feijão obtido na primeira metodologia empregada, ou seja, do feijão triturado antes da adição da água.

Para comparação das metodologias de extração, 50 e $100 \mathrm{~mL}$ de extrato de feijão-de-porco, obtido na segunda metodologia, foram adicionados a $100 \mathrm{~g}$ de excreta.

Para verificar se o feijão resultante da filtragem a vácuo influenciaria na volatilização da amônia proveniente da excreta adicionaram-se 50 e $100 \mathrm{~g}$ de feijão triturado a $100 \mathrm{~g}$ de excreta.

Todos os ensaios foram finalizados no sétimo dia.

\subsubsection{Influência da temperatura}

Com o intuito de verificar a influência da temperatura na volatilização da amônia, frascos com capacidade de 1,3 L, contendo $100 \mathrm{~g}$ de excreta, foram incubados em diferentes temperaturas. A excreta foi coletada no sétimo dia de acúmulo e os animais alimentados com ração comercial.

Um frasco controle permaneceu na capela a uma temperatura de aproximadamente $20^{\circ} \mathrm{C}$ e outros três frascos permaneceram em estufa nas temperaturas de 30,50 e $70^{\circ} \mathrm{C}$. O tempo de incubação foi de 24 horas. Após esse período os frascos foram abertos e a solução fixadora de ácido bórico titulada com solução padrão de hidróxido de sódio no caso do controle e com solução padrão de ácido sulfúrico para as diferentes temperaturas de incubação. 


\subsubsection{Influência da temperatura e do $\mathrm{pH}$ - concentração de carbonato de sódio}

Depois de constatada a influência positiva da temperatura na volatilização da amônia, outro parâmetro foi acrescentado ao estudo. Resultados tanto para a cama de frango quanto para a excreta indicaram a influência positiva da adição de carbonato de sódio, com conseqüente aumento do valor de $\mathrm{pH}$, na volatilização da amônia. Deste modo os parâmetros estudados concomitantemente foram a temperatura e o $\mathrm{pH}$.

$\mathrm{Na}$ análise da influência do parâmetro temperatura, as concentrações de amônia determinadas nas temperaturas de 30 e $50^{\circ} \mathrm{C}$ foram próximas, assim, a temperatura intermediária de $40^{\circ} \mathrm{C}$ foi escolhida. Em relação à concentração de carbonato de sódio, a concentração de $39 \%$ apresentou maior eficácia em experimentos anteriores e foi empregada nesse ensaio.

Um frasco com capacidade de 1,3 L contendo $100 \mathrm{~g}$ de excreta homogeneizada com $39 \mathrm{~g}$ de carbonato de sódio foi incubado a $40^{\circ} \mathrm{C}$ em estufa por 24 horas. O controle consistiu de um frasco com mesma capacidade e mesma quantidade de excreta, sem a adição do carbonato, o qual permaneceu na capela em temperatura de aproximadamente $20^{\circ} \mathrm{C}$, também por 24 horas.

A excreta foi coletada no sétimo dia de acúmulo e os animais alimentados com ração comercial.

Após o período de incubação os frascos foram abertos e a solução fixadora de ácido bórico do controle titulada com solução padrão de hidróxido de sódio e a do frasco teste, que permaneceu em estufa, com solução padrão de ácido sulfúrico.

\subsubsection{Testes com o reformador de amônia}

A amônia obtida em qualquer das etapas introduzidas neste trabalho pode ser transformada em hidróxido de amônio. A solubilidade da amônia em água é função da temperatura, variando de $47 \%$ a $0^{\circ} \mathrm{C}$ até $18 \%$ a $50^{\circ} \mathrm{C}$ [95]. 
Sabendo-se da solubilidade da amônia em água e levando-se em conta que o sistema produtivo de ovos de galinha gera toneladas de resíduos, a retenção da amônia, em determinado tempo, pode gerar grandes quantidades de soluções concentradas de amônia.

No intuito de simular a obtenção de hidrogênio a partir da amônia foram realizados testes em um reformador com uma solução 2 mol.L $\mathrm{L}^{-1}$ em amônia.

No reformador, a solução de hidróxido de amônio é bombeada, até um primeiro forno onde atinge a temperatura de $200{ }^{\circ} \mathrm{C}$ para que a solução evapore. Esse vapor é conduzido para o segundo forno, no qual se encontra um leito de catalisadores composto por $30 \mathrm{~g}$ de manganês metálico, $10 \mathrm{~g}$ de limalha de ferro e camadas de carbeto de silício, o qual permite a transferência de calor. A temperatura do segundo forno foi de até $600^{\circ} \mathrm{C}$.

Caso a reforma da solução de hidróxido de amônio não se dê por completa a quantidade residual pode ser retida com uma solução ácida.

O gás proveniente do segundo forno após passar por peneiras moleculares e sílica gel, para a retirada da umidade, é coletado em uma ampola para amostra de gás. A coleta do gás para análise foi realizada por uma micro seringa para cromatografia a gás da marca Hamilton com volume de $1,0 \mathrm{~mL}$. A primeira e a segunda amostra de gás de reforma coletada são descartadas e a terceira injetada no cromatógrafo.

O cromatógrafo a gás utilizado foi da marca Agilent, modelo $7890 \mathrm{~A}$. 


\section{RESULTADOS E DISCUSSÃO}

\subsection{Caracterização das amostras}

\subsubsection{Fluorescência de Raios-X}

Os resultados da análise de Fluorescência de Raios- $X$ das amostras de cama de frango e excreta estão apresentados na TAB. 8.

TABELA 8 - Resultados da análise semi-quantitativa da cama de frango e da excreta realizada usando a técnica de Fluorescência de Raios-X

\begin{tabular}{|c|c|}
\hline \multicolumn{2}{|c|}{ Cama de Frango } \\
\hline Elemento & Teor (\%) \\
\hline Perda ao Fogo & 88,96 \\
\hline K & $3,4 \pm 0,1$ \\
\hline $\mathrm{Ca}$ & $2,2 \pm 0,1$ \\
\hline$P$ & $1,90 \pm 0,05$ \\
\hline $\mathrm{Mg}$ & $1,04 \pm 0,05$ \\
\hline & Teor (mg.kg $\left.{ }^{-1}\right)$ \\
\hline $\mathrm{Cl}$ & $9794 \pm 100$ \\
\hline$S$ & $5527 \pm 50$ \\
\hline $\mathrm{Na}$ & $3950 \pm 40$ \\
\hline $\mathrm{Si}$ & $2207 \pm 30$ \\
\hline $\mathrm{Al}$ & $1108 \pm 20$ \\
\hline $\mathrm{Fe}$ & $894 \pm 20$ \\
\hline $\mathrm{Zn}$ & $426 \pm 20$ \\
\hline $\mathrm{Cu}$ & $369 \pm 20$ \\
\hline $\mathrm{Mn}$ & $284 \pm 20$ \\
\hline $\mathrm{Sr}$ & $20 \pm 5$ \\
\hline $\mathrm{Br}$ & $8 \pm 3$ \\
\hline As & $3 \pm 2$ \\
\hline $\mathrm{Pb}$ & $1 \pm 1$ \\
\hline
\end{tabular}

\begin{tabular}{|c|c|}
\hline \multicolumn{2}{|c|}{ Excreta } \\
\hline Elemento & Teor (\%) \\
\hline Perda ao Fogo & 93,40 \\
\hline $\mathrm{Ca}$ & $3,1 \pm 0,1$ \\
\hline $\mathrm{K}$ & $1,3 \pm 0,1$ \\
\hline & Teor $\left(\mathrm{mg} \cdot \mathrm{kg}^{-1}\right)$ \\
\hline$P$ & $9561 \pm 100$ \\
\hline $\mathrm{Mg}$ & $4805 \pm 50$ \\
\hline $\mathrm{Cl}$ & $1848 \pm 30$ \\
\hline Si & $1722 \pm 30$ \\
\hline$S$ & $1189 \pm 30$ \\
\hline $\mathrm{Na}$ & $926 \pm 30$ \\
\hline $\mathrm{Al}$ & $752 \pm 30$ \\
\hline $\mathrm{Fe}$ & $354 \pm 20$ \\
\hline $\mathrm{Mn}$ & $114 \pm 20$ \\
\hline $\mathrm{Zn}$ & $113 \pm 20$ \\
\hline $\mathrm{Sr}$ & $51 \pm 10$ \\
\hline $\mathrm{Cu}$ & $17 \pm 5$ \\
\hline $\mathrm{Rb}$ & $4 \pm 1$ \\
\hline
\end{tabular}


Pode-se notar pela tabela que alguns elementos químicos devem ser provenientes da maravalha de madeira, uma vez que são encontrados somente na cama de frango e não na excreta. Representando a excreta um risco menor para deposição em solo.

\subsubsection{Análise Elementar CHN}

As médias dos resultados da análise elementar $\mathrm{CHN}$ das amostras de cama de frango e excreta com e sem umidade são mostradas na TAB. 9.

TABELA 9 - Média dos resultados da análise elementar por CHN das amostras de cama de frango e excreta

\begin{tabular}{lccc}
\hline \multicolumn{1}{c}{ Amostra } & \multicolumn{3}{c}{ Resultados (\%) } \\
\cline { 2 - 4 } & Carbono & Hidrogênio & Nitrogênio \\
\hline Cama de frango úmida & 20,19 & 5,80 & 1,66 \\
Excreta úmida - ração comercial & 9,71 & 4,69 & 0,66 \\
Cama de frango sem umidade & 36,45 & 5,39 & 4,38 \\
Excreta sem umidade - ração comercial & 30,99 & 3,91 & 3,72 \\
Excreta sem umidade - ração comercial & 36,17 & 4,92 & 3,47 \\
Excreta sem umidade - ração em teste & 32,31 & 4,04 & 6,81 \\
\hline
\end{tabular}

Dos resultados da análise elementar $\mathrm{CHN}$ o elemento de maior interesse para esse estudo é o nitrogênio, pois a decomposição de seus compostos acarreta a volatilização de amônia.

A cama de frango apresentou maior teor de nitrogênio quando comparado com a excreta das aves alimentadas com ração comercial tanto nas amostras úmidas como nas secas. Esse maior teor de nitrogênio pode ser atribuído também ao nitrogênio contido na madeira e por isso não implica na volatilização de amônia. 
O maior teor de proteína bruta, contido na ração teste, resultou em um maior teor de nitrogênio na excreta das aves alimentadas com esse tipo ração.

\subsubsection{Termogravimetria}

As curvas TG das amostras de cama de frango e de excreta apresentaram quatro eventos significativos de perda de massa. A massa inicial das amostras, 0 intervalo de temperatura $\left({ }^{\circ} \mathrm{C}\right)$, a temperatura de pico $\left({ }^{\circ} \mathrm{C}\right)$ e a perda de massa $(\mathrm{mg}$ e \%) de cada evento estão apresentadas na TAB. 10.

TABELA 10 - Dados da decomposição térmica das amostras de cama de frango e excreta

\begin{tabular}{|c|c|c|c|c|c|c|}
\hline \multirow{2}{*}{ Amostras } & \multirow{2}{*}{$\begin{array}{c}\text { Massa } \\
(\mathrm{mg})\end{array}$} & \multirow{2}{*}{ Parâmetros } & \multicolumn{4}{|c|}{ Eventos } \\
\hline & & & $1^{\circ}$ & $2^{\circ}$ & $3^{\circ}$ & $4^{\circ}$ \\
\hline \multirow{4}{*}{$\begin{array}{l}\text { Cama de } \\
\text { Frango }\end{array}$} & \multirow{4}{*}{34,5} & $\begin{array}{l}\text { Intervalo de } \\
\text { temp. }\left({ }^{\circ} \mathrm{C}\right)\end{array}$ & $27-121$ & $209-278$ & 278-330 & $388-510$ \\
\hline & & $\begin{array}{l}\text { Temp. de pico } \\
\left({ }^{\circ} \mathrm{C}\right)\end{array}$ & 78,78 & 259,13 & 309,30 & 452 \\
\hline & & $\begin{array}{c}\text { Perda de } \\
\text { massa }(\mathrm{mg})\end{array}$ & 3,6 & 4,8 & 5,6 & 7,6 \\
\hline & & $\begin{array}{l}\text { Perda de } \\
\text { massa (\%) }\end{array}$ & 36,2 & 48,6 & 56,6 & 76,9 \\
\hline \multirow{4}{*}{ Excreta } & \multirow{4}{*}{9,9} & $\begin{array}{l}\text { Intervalo de } \\
\text { temp. }\left({ }^{\circ} \mathrm{C}\right)\end{array}$ & $28-156$ & $205-286$ & $286-328$ & $423-538$ \\
\hline & & $\begin{array}{c}\text { Temp. de pico } \\
\left({ }^{\circ} \mathrm{C}\right)\end{array}$ & 114,04 & 263,88 & 310,34 & 464,10 \\
\hline & & $\begin{array}{c}\text { Perda de } \\
\text { massa (mg) }\end{array}$ & 23,7 & 25,9 & 26,8 & 29,9 \\
\hline & & $\begin{array}{c}\text { Perda de } \\
\text { massa (\%) }\end{array}$ & 68,6 & 75,2 & 77,7 & 86,6 \\
\hline
\end{tabular}

A curva termogravimétrica (TG) e sua derivada (DTG) para a cama de frango é mostrada na FIG. 12. 


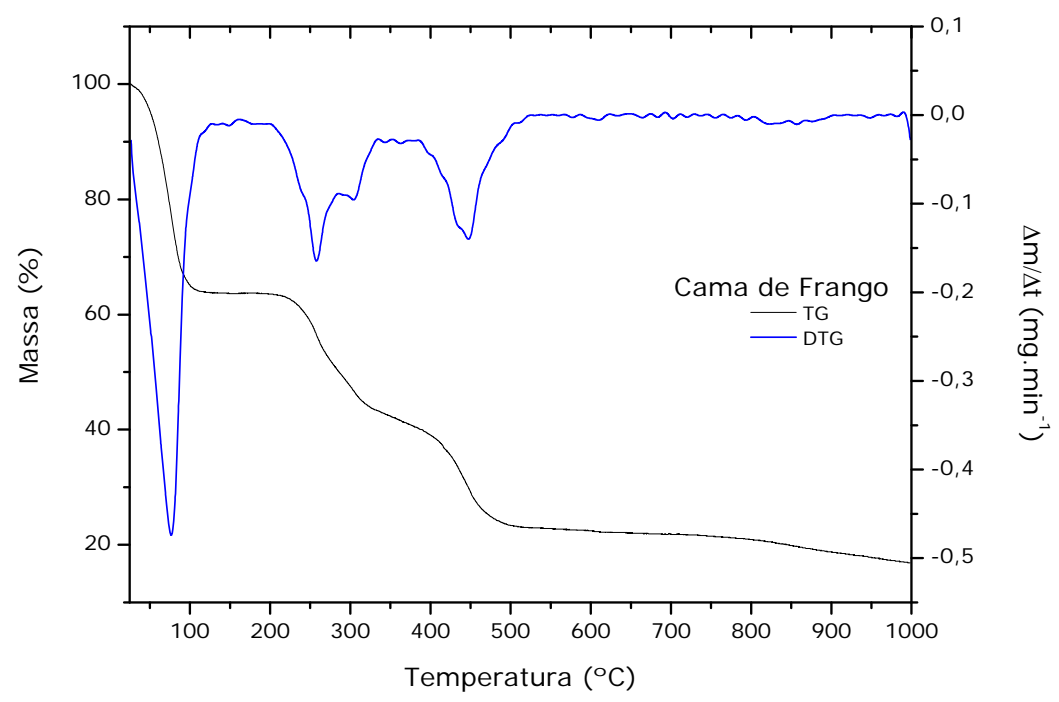

FIGURA 12 - Cama de frango - curva termogravimétrica (TG) e curva termogravimétrica derivada (DTG)

O primeiro evento, entre 27 e $121^{\circ} \mathrm{C}$ é característico da eliminação dos voláteis. A amônia, foco deste estudo, é volatilizada anteriormente à água. Por isso a denominação de voláteis e não somente de umidade. O teor de voláteis associado a essa etapa foi de $36,2 \%$. Os eventos seguintes estão relacionados com a decomposição térmica do material. O segundo evento acontece em duas etapas consecutivas e concomitantes, pois antes do término da segunda decomposição térmica inicia-se o terceiro evento de perda de massa. Ao final do terceiro evento a perda de massa em relação à massa inicial foi de $56,6 \%$. Acredita-se que na faixa de temperatura entre 388 e $510^{\circ} \mathrm{C}$, ocorreu o último evento de decomposição térmica de matéria orgânica. A partir da temperatura de $510^{\circ} \mathrm{C}$ a amostra continuou perdendo massa. Acima da temperatura de $900^{\circ} \mathrm{C}$ a massa residual foi denominada de cinzas, composta de material inorgânico. 0 teor de cinzas da amostra de cama de frango, observado na temperatura de $998,49^{\circ} \mathrm{C}$ foi de $16,9 \%$ da massa original. 
A curva termogravimétrica (TG) e sua derivada (DTG) para a excreta é mostrada na FIG. 13.

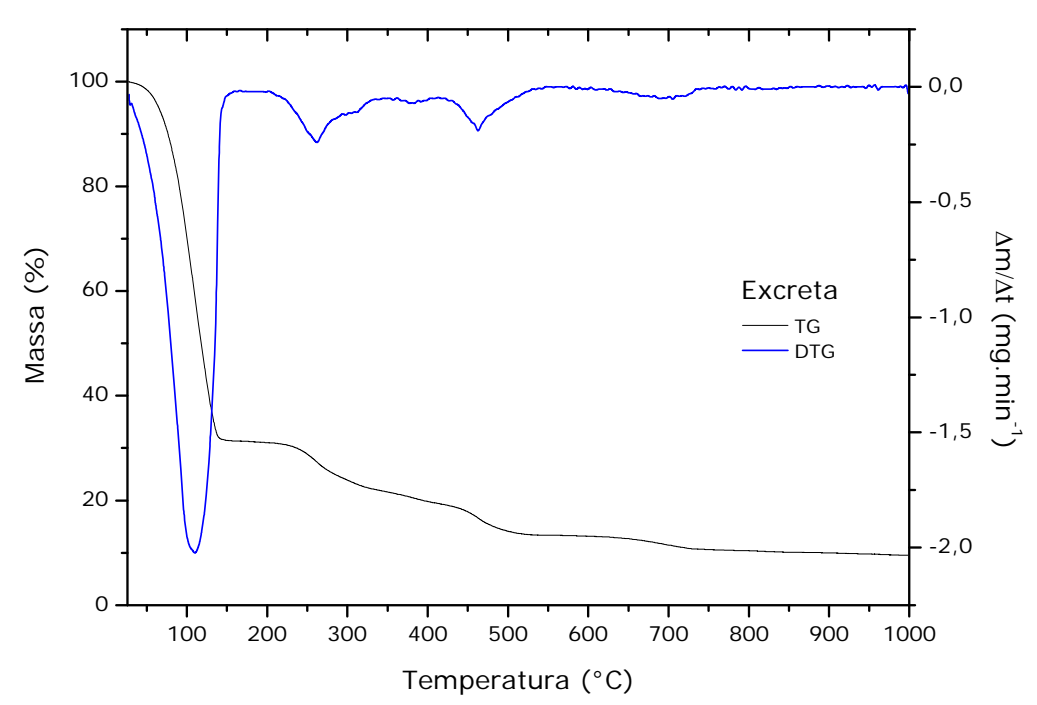

FIGURA 13 - Excreta - curva termogravimétrica (TG) e curva termogravimétrica derivada (DTG)

As curvas TG/DTG da amostra de excreta evidenciam um maior teor de voláteis quando comparadas com a cama de frango. No primeiro evento ocorrido entre 28 e $156^{\circ} \mathrm{C}$ a perda de massa, em relação à massa inicial de $9,9 \mathrm{mg}$, foi de $68,6 \%$. Nos eventos seguintes as perdas de massa foram menores do que a do primeiro evento. O segundo e o terceiro eventos foram concomitantes. O quarto evento representa a última etapa da decomposição da matéria orgânica. O teor de cinzas da amostra de excreta, observado na temperatura de $998,48^{\circ} \mathrm{C}$ foi de $9,5 \%$ da massa original.

A maior fração das duas amostras é composta de matéria orgânica. Nos dois materiais, cama de frango e excreta, a decomposição térmica ocorreu em quatro eventos.

Pan et al. [96] realizaram a análise termogravimétrica da cama de frango proveniente de um sistema produtivo de frango do estado americano Kentucky por meio das técnicas de TGA-MS - Análise Termogravimétrica com Espectrometria de Massa e pela técnica TGA-FTIR - Termogravimetria Acoplada a Espectroscopia na Região do Infravermelho. O uso das duas técnicas permitiu a 
determinação dos gases envolvidos em cada evento de decomposição. A curva termogravimétrica indica quatro eventos principais de decomposição, o que corrobora os resultados obtidos neste estudo. Na FIG. 14 pode ser visualizada a curva termogravimétrica e os gases envolvidos nos eventos de decomposição da cama de frango.

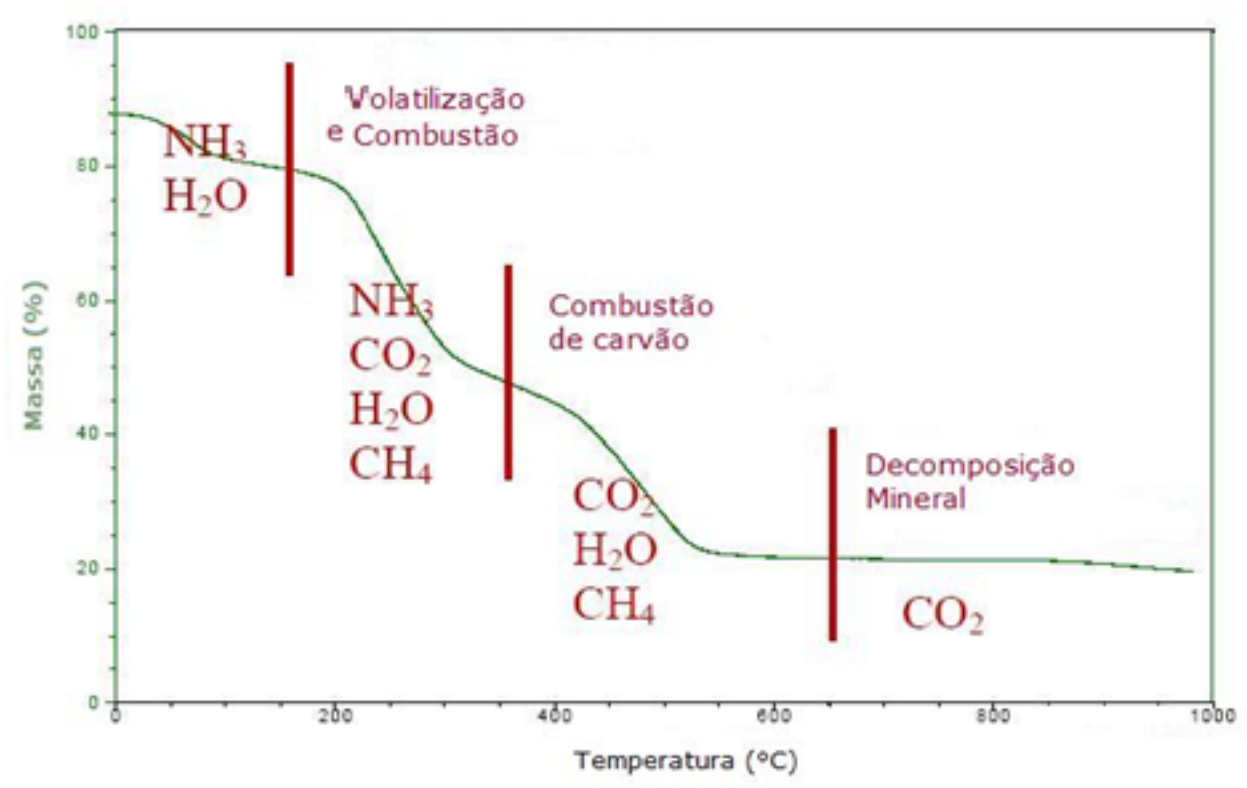

FIGURA 14 - Curva termogravimétrica e gases envolvidos na decomposição da cama de frango

Fonte: Pan et al., 2004 [96].

O primeiro evento está associado à volatilização de amônia e água. No segundo evento, definido como volatilização e combustão, ocorre a liberação de amônia, dióxido de carbono, água ligada e metano. O terceiro evento, denominado combustão de carvão, é caracterizado pela eliminação de dióxido de carbono, água e metano. O quarto evento refere-se à decomposição mineral e nessa temperatura somente o dióxido de carbono foi identificado.

Neste trabalho também foram determinados os teores de voláteis e de cinzas da cama de frango e da excreta. A diferença nesses teores, quando comparados os dois materiais, advém das diferenças na composição. A amostra de cama de frango, além da excreta das aves, de restos de penas e alimentos, é composta por maravalha de madeira. Os teores de voláteis e de cinzas são apresentados na TAB. 11. 
TABELA 11 - Teores de voláteis e de cinzas das amostras de cama de frango e excreta

\begin{tabular}{ccc}
\hline Amostras & Teor de voláteis (\%) & Teor de cinzas (\%) \\
\hline Cama de Frango & 36,2 & 16,9 \\
\hline Excreta & 68,6 & 9,5 \\
\hline
\end{tabular}

Os valores obtidos por Termogravimetria são diferentes dos que são apresentados nos itens teor de voláteis e perda ao fogo. Essa variação pode ser explicada pela heterogeneidade das amostras, data de coleta diferente (excreta) e pela amostragem. Na determinação da umidade e da perda ao fogo da cama de frango e da excreta foi utilizado $1 \mathrm{~g}$ de amostra e a determinação foi feita em triplicata. Em massas menores a margem de erro pode ser maior. $\mathrm{Na}$ Termogravimetria a massa inicial da cama de frango foi de $34,5 \mathrm{mg}$ e a da excreta de $9,9 \mathrm{mg}$. 
A Análise Térmica Diferencial (DTA) indicou os eventos endotérmicos e os exotérmicos da decomposição das amostras. Na FIG. 15 e 16 são apresentados os resultados da DTA das amostras de cama de frango e da excreta.

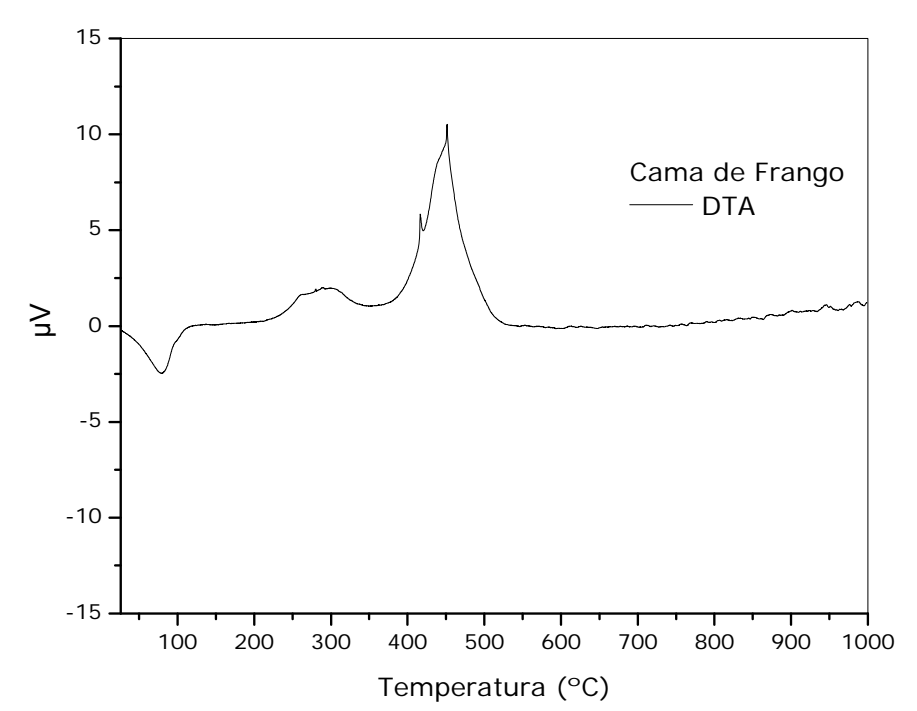

FIGURA 15 - Cama de frango - Análise Térmica Diferencial DTA

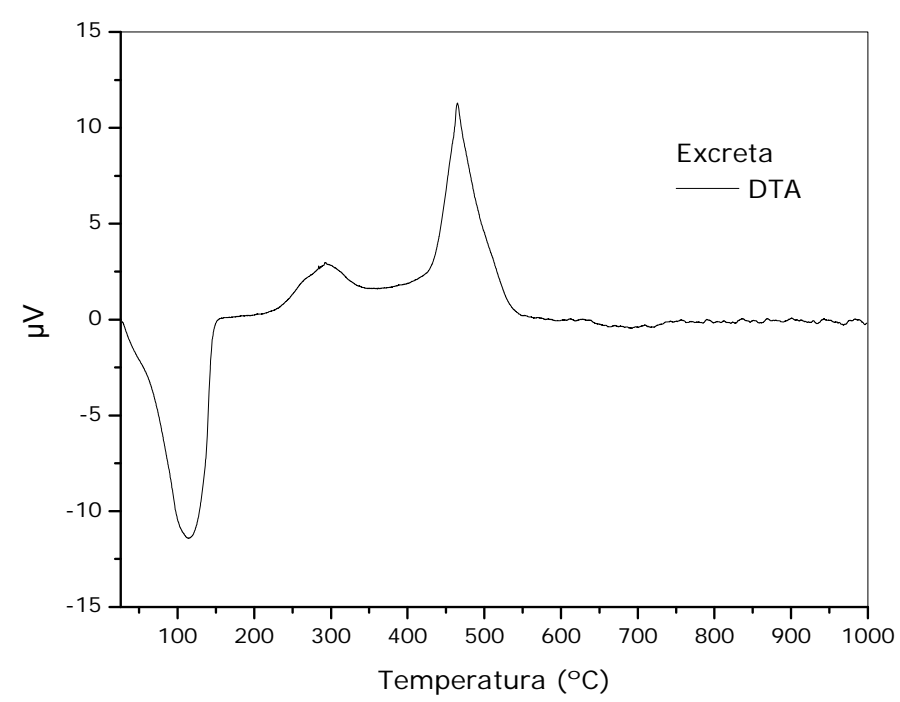

FIGURA 16 - Excreta - Análise Térmica Diferencial DTA

Os picos ascendentes caracterizam os eventos exotérmicos e os descendentes os endotérmicos. Nas duas amostras é possível visualizar um primeiro evento endotérmico, referente à perda de água e de voláteis, característico da entalpia de volatilização. O segundo e o terceiro eventos são 
exotérmicos. No terceiro evento, exotérmico, ocorreu a oxidação das amostras, iniciada com a combustão de parte da matéria orgânica.

Como a amostra de excreta apresenta maior teor de umidade em relação à cama de frango, no primeiro evento, endotérmico, foi observado um maior consumo de energia para a eliminação dos voláteis.

Depois de esgotada a liberação de amônia pela cama de frango ou pela excreta, esse material ainda pode ser aproveitado. Uma das opções para o aproveitamento energético desse resíduo é a gaseificação.

Embora o maior teor de cinzas observado tenha sido nas amostras de cama de frango, esse material mostrou-se mais adequado à gaseificação. Esse fato deve-se ao menor consumo de energia para a eliminação dos voláteis, o qual pode ser observado na comparação das intensidades do pico endotérmico em relação ao pico exotérmico.

Outros parâmetros devem ser estudados para determinação da eficiência energética da gaseificação desses resíduos.

\subsubsection{Cromatografia a Gás acoplada à Espectrometria de Massa GC/MS}

Os compostos foram identificados por meio de software no qual os espectros de massa obtidos foram comparados com espectros do banco de dados do NIST - Instituto Nacional de Padrões e Tecnologia [97].

O cromatograma da análise especifica os tempos de retenção dos compostos presentes em cada uma das amostras, a fórmula molecular, o peso molecular e o Chemical Abstract Service - CAS number. As definições desses termos estão especificadas a seguir:

Tr - Tempo de retenção em minutos. Parâmetro cromatográfico que representa o tempo de demora, isto é de eluição do composto químico através da coluna cromatográfica.

Composto - Nome do composto químico detectado no referido tempo de retenção. 
Molécula - Fórmula Molecular do composto químico detectado.

PM - Peso molecular do composto químico analisado.

CAS - Número do Chemical Abstract Service (CAS number) que identifica um único composto químico.

Os resultados da análise por GC/MS da cama de frango úmida podem ser visualizados na FIG. 17 e na TAB. 12.

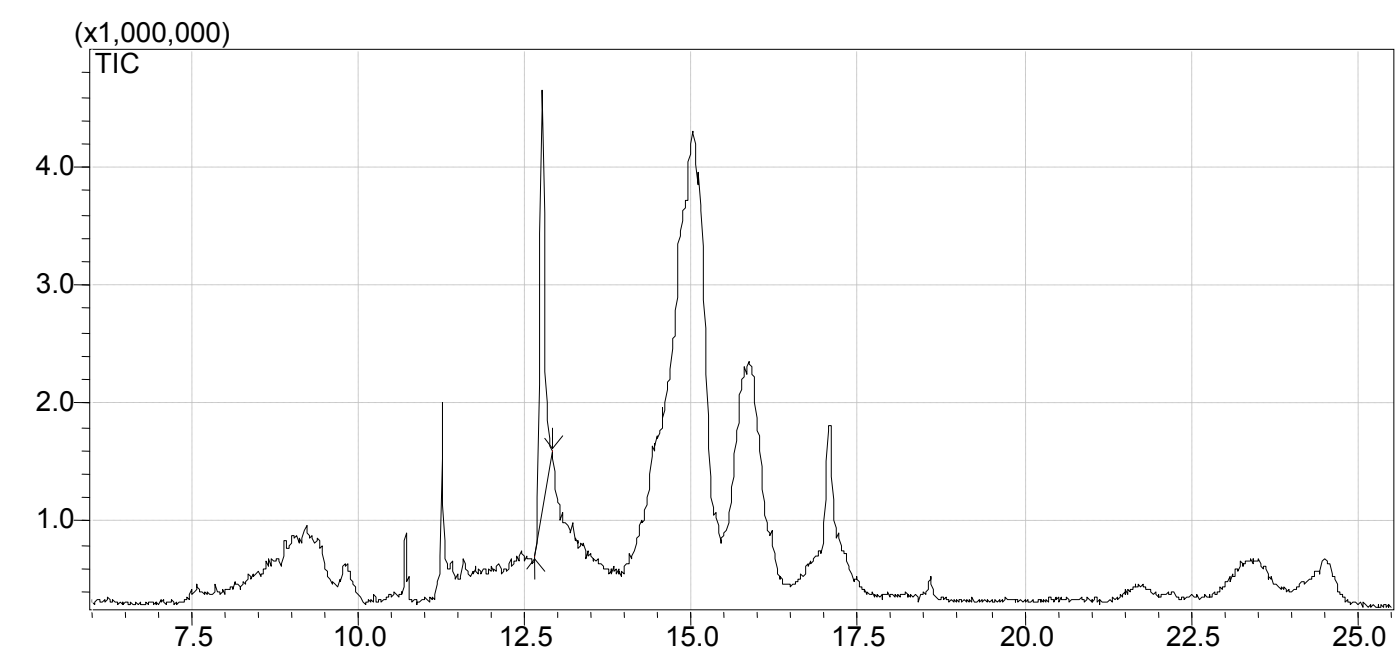

FIGURA 17 - Cromatograma GC/MS da cama de frango úmida

TABELA 12 - Características dos compostos identificados por GC/MS da amostra da cama de frango úmida

\begin{tabular}{cccccc}
\hline$n^{\circ}$ & $\begin{array}{c}\mathrm{Tr} \\
(\text { min. })\end{array}$ & Composto & Molécula & $\mathrm{PM}$ & CAS \\
\hline 1 & 10,7 & Didodecyl phthalate & $\mathrm{C}_{32} \mathrm{H}_{54} \mathrm{O}_{4}$ & 502 & $2432-90-8$ \\
2 & 11,2 & Hexadecanoic acid & $\mathrm{C}_{16} \mathrm{H}_{32} \mathrm{O}_{2}$ & 256 & $57-10-3$ \\
3 & 12,7 & Oleic acid & $\mathrm{C}_{18} \mathrm{H}_{34} \mathrm{O}_{2}$ & 282 & $112-80-1$ \\
4 & 15,0 & $\begin{array}{c}\text { Docosahexaenoic acid, 1,2,3- } \\
\text { propanetriyl ester }\end{array}$ & $\mathrm{C}_{69} \mathrm{H}_{98} \mathrm{O}_{6}$ & 1022 & $11094-59-0$ \\
5 & 15,8 & $\begin{array}{c}\text { Methyl (Z)-5,11,14,17- } \\
\text { eicosatetraenoate }\end{array}$ & $\mathrm{C}_{21} \mathrm{H}_{34} \mathrm{O}_{2}$ & 318 & $0-00-0$ \\
6 & 17,0 & $10-U n d e c e n a l$ & $\mathrm{C}_{11} \mathrm{H}_{20} \mathrm{O}$ & 168 & $112-45-8$ \\
\hline
\end{tabular}


Os resultados da análise por GC/MS da cama de frango sem umidade podem ser visualizados na FIG. 18 e na TAB. 13.

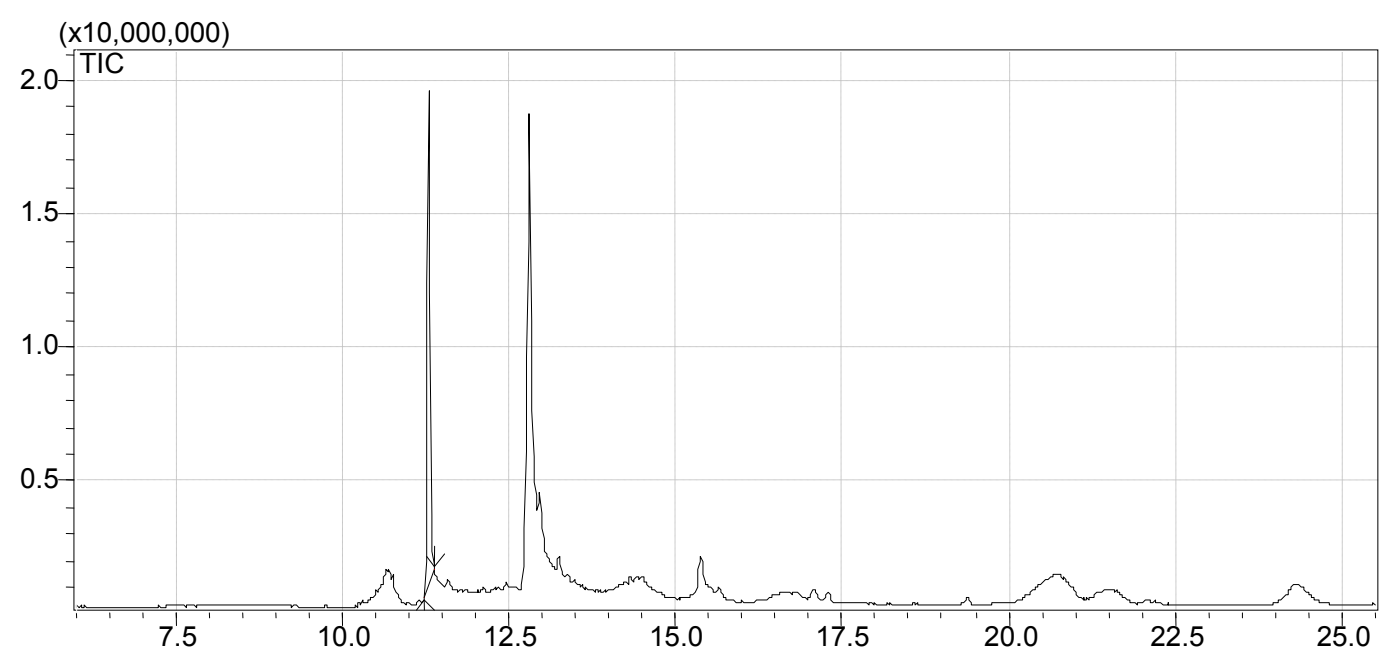

FIGURA 18 - Cromatograma GC/MS da cama de frango sem umidade

TABELA 13 - Características dos compostos identificados por GC/MS da amostra da cama de frango sem umidade

\begin{tabular}{|c|c|c|c|c|c|}
\hline $\mathrm{n}^{\circ}$ & $\operatorname{Tr}$ (min.) & Composto & Molécula & PM & CAS \\
\hline 1 & 11,3 & Hexadecanoic acid & $\mathrm{C}_{16} \mathrm{H}_{32} \mathrm{O}_{2}$ & 256 & $57-10-3$ \\
\hline 2 & 12,8 & Oleic acid & $\mathrm{C}_{18} \mathrm{H}_{34} \mathrm{O}_{2}$ & 282 & $112-80-1$ \\
\hline
\end{tabular}


Os resultados da análise por GC/MS da excreta úmida podem ser visualizados na FIG. 19 e na TAB. 14.

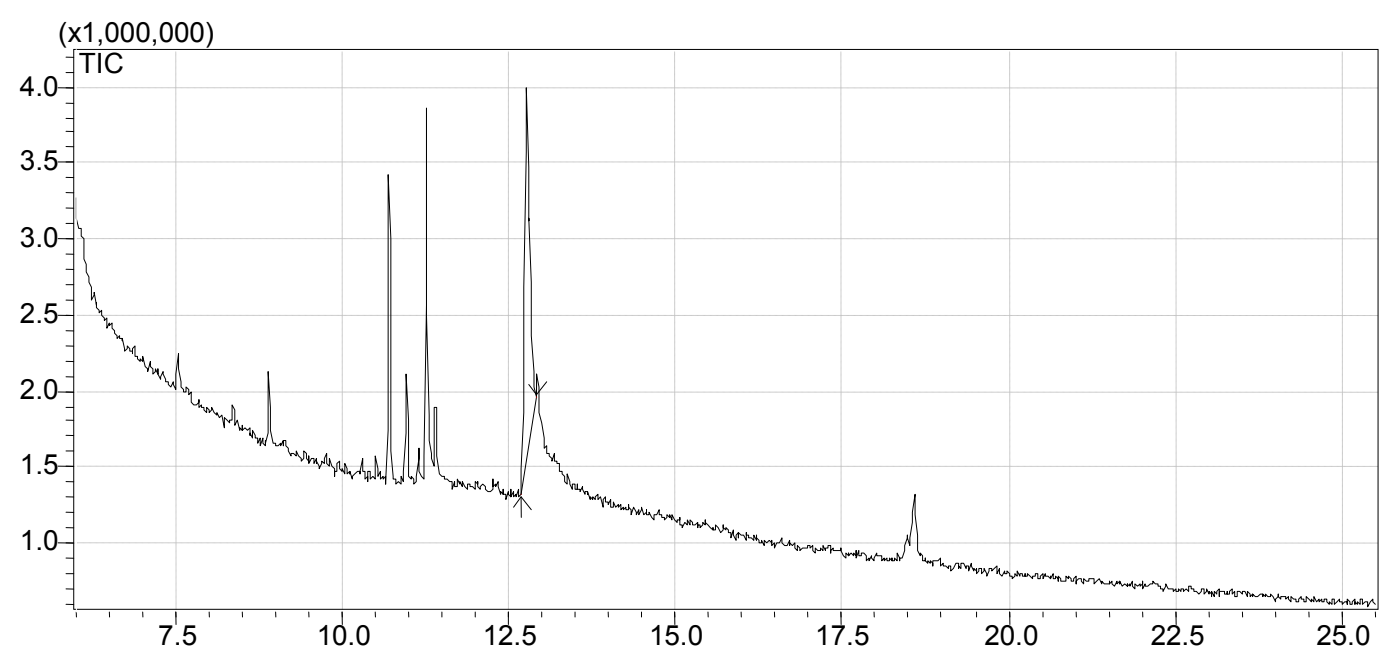

FIGURA 19 - Cromatograma GC/MS da excreta úmida

TABELA 14 - Características dos compostos identificados por GC/MS da amostra da excreta úmida

\begin{tabular}{|c|c|c|c|c|c|}
\hline$n^{0}$ & $\begin{array}{c}\operatorname{Tr} \\
(\min .)\end{array}$ & Composto & Molécula & PM & CAS \\
\hline 1 & 10,7 & $\begin{array}{c}\text { 1,2-Benzenedicarboxylic acid, } \\
\text { bis(2-methylpropyl) ester }\end{array}$ & $\mathrm{C}_{16} \mathrm{H}_{22} \mathrm{O}_{4}$ & 278 & $84-69-5$ \\
\hline 2 & 10,9 & $\begin{array}{c}\text { Methanamine, } \mathrm{N} \text { - } \\
\text { (phenylmethylene)-, } \mathrm{N} \text {-oxide }\end{array}$ & $\mathrm{C}_{8} \mathrm{H}_{9} \mathrm{NO}$ & 135 & $3376-23-6$ \\
\hline 3 & 11,2 & Hexadecanoic acid & $\mathrm{C}_{16} \mathrm{H}_{32} \mathrm{O}_{2}$ & 256 & $57-10-3$ \\
\hline 4 & 11,4 & Dibutyl phthalate & $\mathrm{C}_{16} \mathrm{H}_{22} \mathrm{O}_{4}$ & 278 & $84-74-2$ \\
\hline 5 & 12,7 & Oleic acid & $\mathrm{C}_{18} \mathrm{H}_{34} \mathrm{O}_{2}$ & 282 & $112-80-1$ \\
\hline
\end{tabular}


Os resultados da análise por GC/MS da excreta sem umidade podem ser visualizados na FIG. 20 e na TAB. 15.

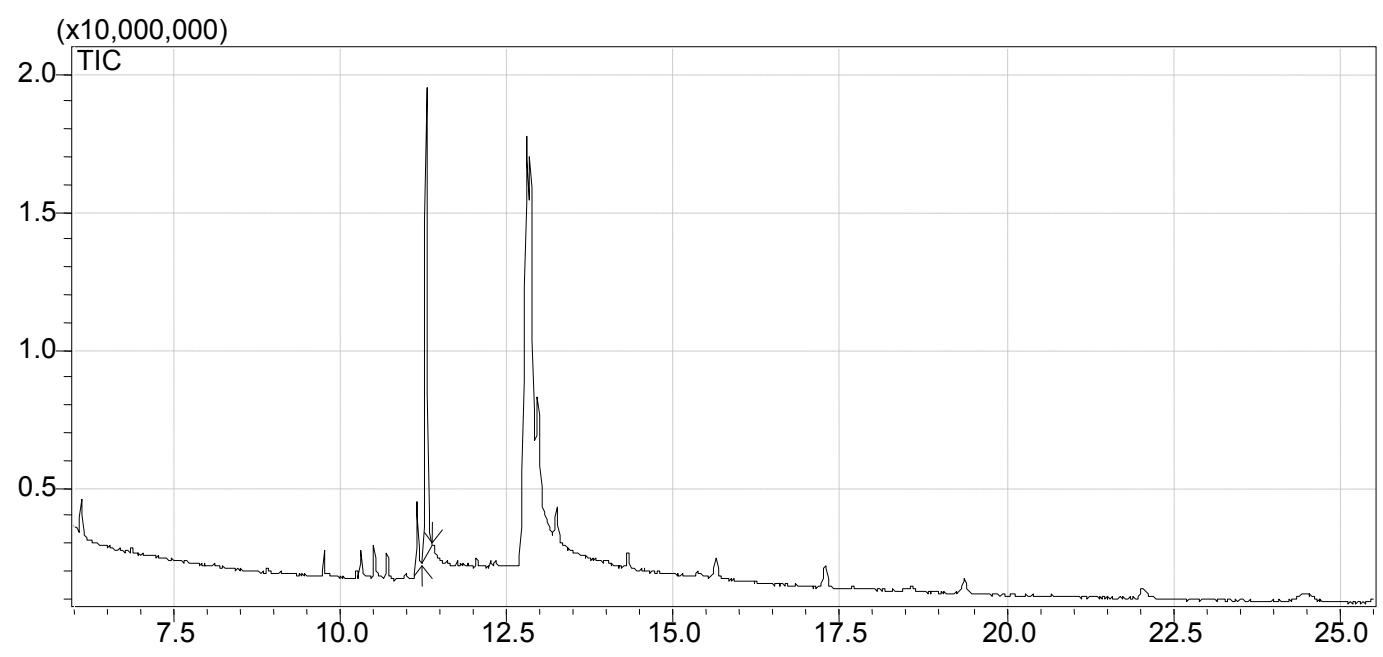

FIGURA 20 - Cromatograma GC/MS da excreta sem umidade

TABELA 15 - Características dos compostos identificados por GC/MS da amostra da excreta sem umidade

\begin{tabular}{|c|c|c|c|c|c|}
\hline$n^{0}$ & $\operatorname{Tr}(\min )$. & Composto & Molécula & PM & CAS \\
\hline 1 & 9,7 & Decanoic acid & $\mathrm{C}_{10} \mathrm{H}_{20} \mathrm{O}_{2}$ & 172 & $334-48-5$ \\
\hline 2 & 10,3 & Octadecanoic acid & $\mathrm{C}_{18} \mathrm{H}_{36} \mathrm{O}_{2}$ & 284 & $57-11-4$ \\
\hline 3 & 10,5 & Pentadecanoic acid & $\mathrm{C}_{15} \mathrm{H}_{30} \mathrm{O}_{2}$ & 242 & $1002-84-2$ \\
\hline 4 & 10,7 & $\begin{array}{c}\text { 1,2-Benzenedicarboxylic acid, } \\
\text { bis(2-methylpropyl) ester }\end{array}$ & $\mathrm{C}_{16} \mathrm{H}_{22} \mathrm{O}_{4}$ & 278 & $84-69-5$ \\
\hline 5 & 11,1 & Oleic acid & $\mathrm{C}_{18} \mathrm{H}_{34} \mathrm{O}_{2}$ & 282 & $112-80-1$ \\
\hline 6 & 11,3 & Hexadecanoic acid & $\mathrm{C}_{16} \mathrm{H}_{32} \mathrm{O}_{2}$ & 256 & $57-10-3$ \\
\hline 7 & 12,7 & Oleic acid & $\mathrm{C}_{18} \mathrm{H}_{34} \mathrm{O}_{2}$ & 282 & $112-80-1$ \\
\hline
\end{tabular}


Os solventes não polares como o diclorometano extraem compostos não polares como as gorduras. A maioria dos compostos identificados são gorduras presentes no frango.

Como exemplos, podemos citar: ácido oléico; ácido hexadecanóico ou ácido palmítico; ácido decanóico ou ácido cáprico; ácido octadecanóico ou ácido esteárico; ácido pentadecanóico e o ácido docosahexaenóico.

A TAB. 16 apresenta os ácidos graxos que compõem a gordura de galinhas domésticas, segundo Hilditch [98]. Este autor cita que o principal depósito de gordura nas aves está localizado nas regiões abdominal e da moela e que há menos gordura no tecido subcutâneo do pescoço e na pele.

TABELA 16 - Composição percentual dos ácidos graxos presentes na gordura de galinhas domésticas

\begin{tabular}{cc}
\hline Ácidos graxos & Massa (\%) \\
\hline $16: 0$ - palmítico & $18,4-19,3$ \\
$18: 0$ - esteárico & $7,5-8,9$ \\
$18: 1-$ oléico & $54,7-55,4$ \\
$18: 2-$ linoléico & $17,8-17,9$ \\
\hline
\end{tabular}

Fonte: Hilditch, 1941 [98]

Esses ácidos graxos encontrados na gordura de galinhas domésticas foram identificados na excreta das aves.

Os derivados de benzeno como o 1,2-Benzenedicarboxylic acid, bis(2methylpropyl) ester e o Dibutyl phthalate também foram identificados em cama de frango com o uso de GC/MS por Pan et al. [96]. O relatório técnico de Pan e colaboradores avaliaram a pirólise e a incineração da cama de frango e o GC/MS foi utilizado para identificar os possíveis compostos que podem servir como reagentes para os produtos gasosos envolvidos. 
As análises por meio do Cromatógrafo a Gás acoplado à Espectrometria de Massas GC/MS foram realizadas para verificar a presença de pesticidas nos resíduos avícolas. No presente ensaio não foram identificados pesticidas. Os derivados de benzeno encontrados tem o ponto de ebulição maior do que o da amônia, não interferindo na coleta deste material.

\subsubsection{Teor de Voláteis}

Na TAB. 17 são apresentados os teores de voláteis da cama de frango e da excreta.

TABELA 17 - Teores de voláteis da cama de frango e da excreta
Amostra
Teor de voláteis $(\%)$

Cama de Frango

54,3

Excreta

28,0

O maior teor de voláteis da cama de frango, constituída de maravalha de madeira e excreta, neste caso, pode ser explicada pela absorção de água durante todo o período de criação pela maravalha de madeira. Esse valor, superior ao ideal de 20 a $25 \%$, favorece a emissão de amônia.

\subsubsection{Perda ao fogo}

Na TAB. 18 são apresentados os valores de perda ao fogo da cama de frango e da excreta.

TABELA 18 - Valores de perda ao fogo da cama de frango e da excreta
Amostra
Perda ao Fogo (\%)

$\begin{array}{cc}\text { Cama de Frango } & 88,96 \\ \text { Excreta } & 93,40\end{array}$


Esses valores foram determinados e correspondem a uma etapa de preparação da amostra para a análise de Fluorescência de Raios- $X$ e indicaram baixos teores de cinzas resultante da queima das amostras.

\subsection{Estudo dos fatores que influenciam a volatilização da amônia}

\subsubsection{Ensaios exploratórios}

Os primeiros experimentos realizados em dessecador utilizaram recipientes contendo água e/ou resina absorvedora para a fixação da amônia volatilizada da cama de frango. Com a adição do reagente Nessler à água que ficou incubada e com o aquecimento em banho-maria, foi observada mudança de cor da solução, que passou de incolor para marrom claro confirmando a presença de amônia. No caso da resina, a alteração da sua própria coloração de rosa para amarela e a necessidade do tratamento com ácido clorídrico para restauração das condições iniciais confirmam o caráter básico decorrente da fixação de amônia, ocorrida durante o período de incubação.

\subsubsection{Experimentos com a cama de frango}

\subsubsection{Influência do pH - concentração de carbonato de sódio}

Titularam-se $10 \mathrm{~mL}$ da solução fixadora de ácido bórico mantida no interior do frasco utilizado como câmara incubadora. Na adição do indicador fenolftaleína as três primeiras concentrações (1, 3 e 5\%) não apresentaram alteração de cor, permanecendo incolores, indicando que a quantidade de amônia gerada não foi suficiente para neutralizar o ácido bórico. Já as duas últimas concentrações testadas (7 e 9\%) alteraram as características da solução mudando seu aspecto de incolor para rosa claro, indicando o caráter básico, devido ao excesso de amônia fixada.

As soluções fixadoras de ácido bórico das três primeiras concentrações de carbonato de sódio foram tituladas com solução padrão de $\mathrm{NaOH}$ e as duas últimas, que mostraram ter captado excesso de amônia, com solução padrão de $\mathrm{H}_{2} \mathrm{SO}_{4}$. Com os dados obtidos na titulação da solução fixadora de ácido bórico 
calculou-se a concentração de amônia (mol.L ${ }^{-1}$ ) fixada. Na FIG. 21 são apresentados estes resultados.

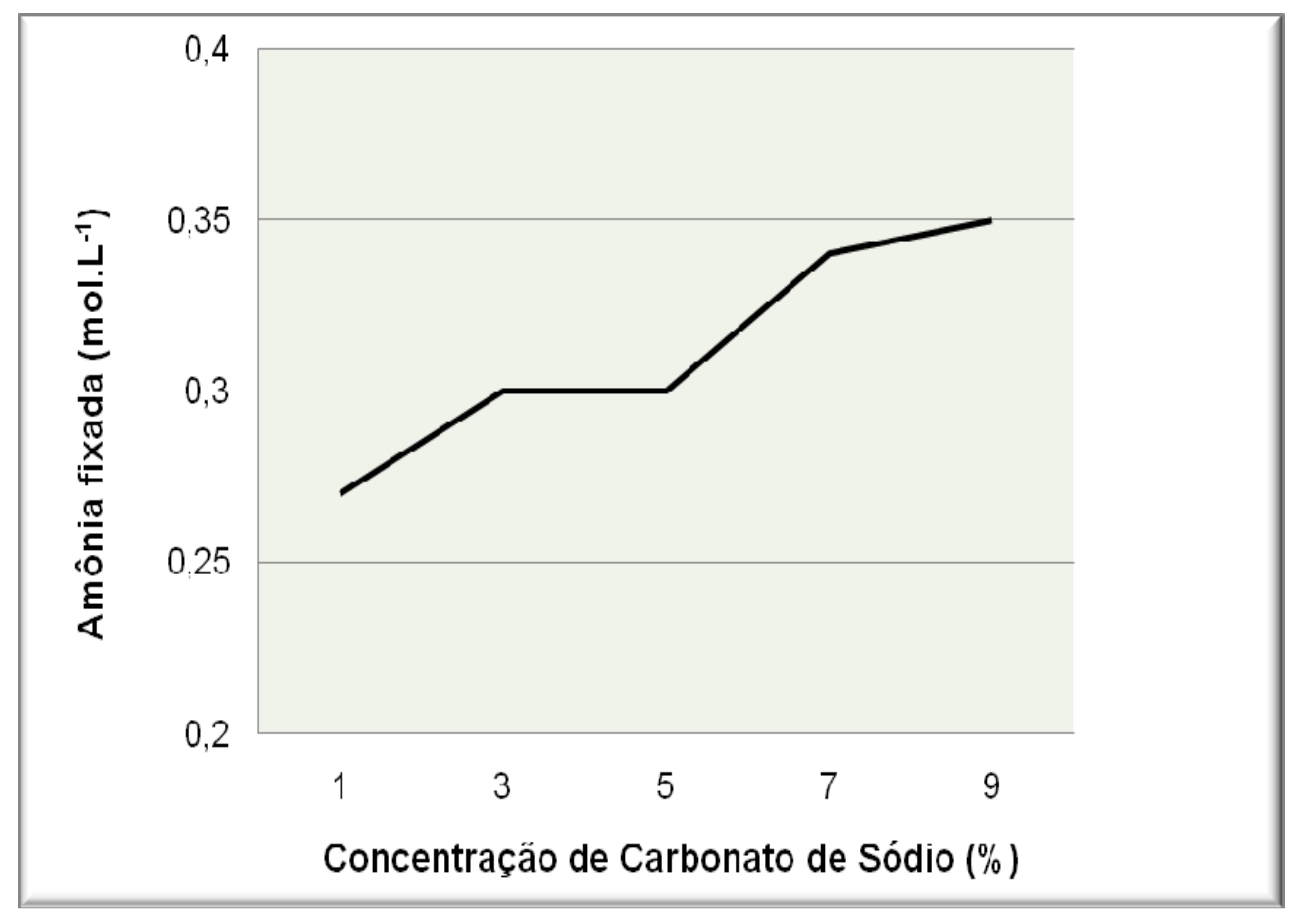

FIGURA 21 - Primeira faixa de concentração de carbonato de sódio e concentração de amônia fixada durante 24 horas de incubação

Nas três primeiras variações das concentrações de carbonato de sódio (1, 3 e 5\%) houve um decréscimo da concentração de ácido bórico a ser neutralizado pela solução padrão de $\mathrm{NaOH}$, mostrando um crescimento na formação de base, ou seja da amônia fixada, com o aumento da concentração de carbonato de sódio.

Nas duas maiores concentrações de carbonato de sódio testadas (7 e 9\%) um volume maior de solução padrão de $\mathrm{H}_{2} \mathrm{SO}_{4}$ foi necessário para neutralizar a concentração de amônia fixada conforme 0 aumento da concentração de carbonato de sódio, uma vez que a quantidade de base gerada foi estequiometricamente superior à necessária para neutralização do ácido bórico.

A segunda faixa de concentração de carbonato de sódio, com 24 horas e com 12 dias de incubação está apresentada na FIG. 22. 


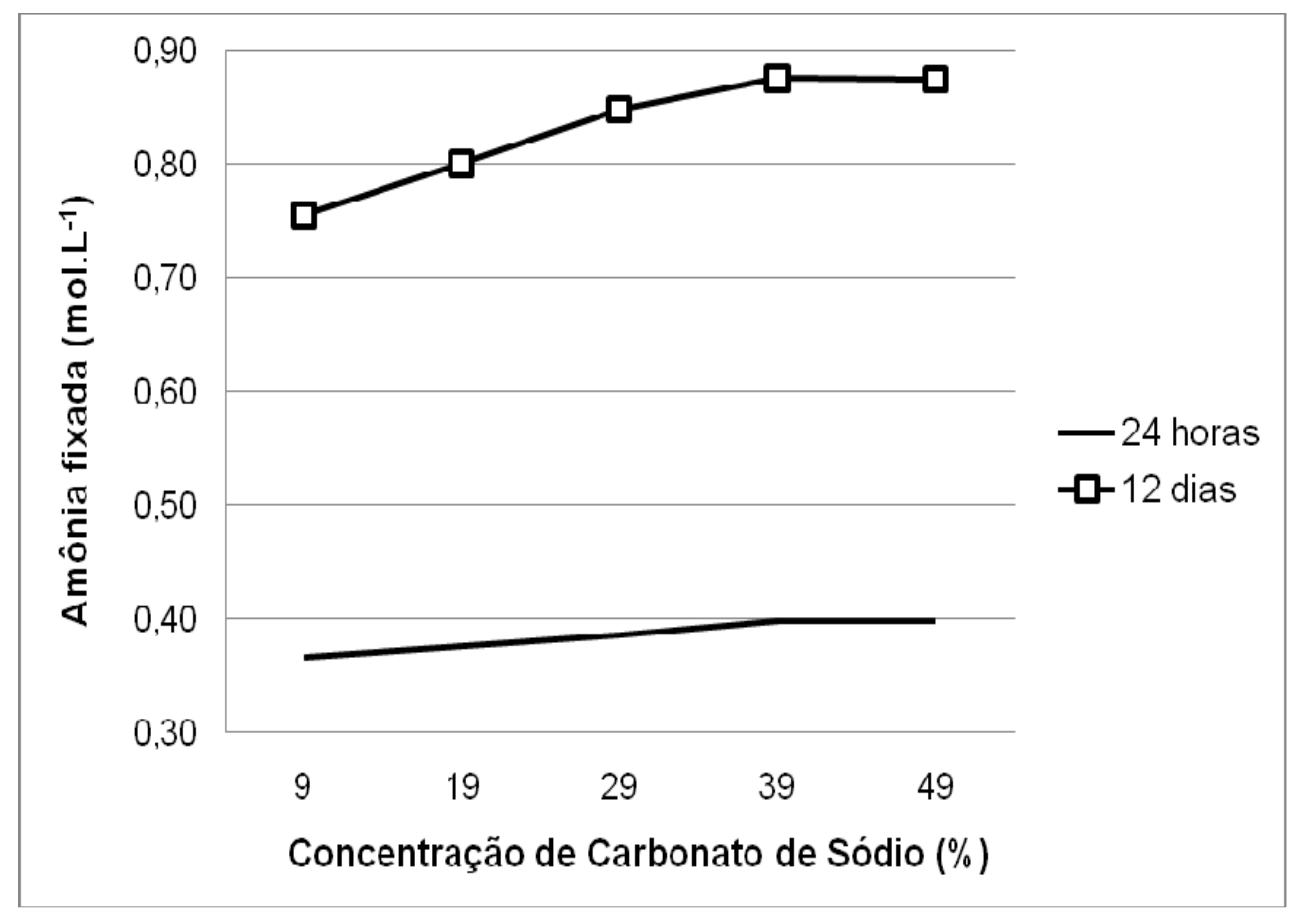

FIGURA 22 - Segunda faixa de concentração de carbonato de sódio e concentração de amônia fixada em 24 horas e em 12 dias de incubação

Pode-se notar que a amônia fixada foi crescente até a concentração de $39 \%$. A partir desta concentração a fixação da amônia se manteve constante. Fez-se, também uma leitura após 12 dias de incubação, notando-se o mesmo comportamento. Considerou-se, assim, concentrações de até 39\% de carbonato de sódio como adequadas para se ter um aumento máximo na volatilização de amônia.

Os resultados comprovam que um aumento no $\mathrm{pH}$ da cama de frango resulta em um aumento na volatilização da amônia. Na TAB. 19 são apresentados os valores de $\mathrm{pH}$ da cama de frango ao final de cada experimento. 
TABELA 19 - Valores de $\mathrm{pH}$ da cama de frango incubada nos frascos com diferentes concentrações de carbonato de sódio

Concentração de Carbonato de Sódio

$(\%)$

$\mathrm{pH}$ da cama de frango

9

19

29

39

49
10,01

10,11

10,22

10,32

10,34

$\mathrm{O}$ aumento do valor de $\mathrm{pH}$ favorece a decomposição microbiana do ácido úrico em amônia. Estudos reportam que o valor de pH ideal para que a enzima uricase, primeira a catalisar a decomposição, está em torno de 9,5 [99, 100]. Nos nossos experimentos esse $\mathrm{pH}$ foi de, aproximadamente, 10,2.

\subsubsection{Influência do volume do frasco}

Os resultados dos experimentos utilizando-se frascos com diferentes volumes, contendo $100 \mathrm{~g}$ de cama de frango e com a concentração de $9 \%$ de carbonato de sódio podem ser visualizados na TAB. 20.

TABELA 20 - Frascos com diferentes volumes e concentração de amônia fixada durante 13 dias

Volume do frasco (L)

Concentração de amônia fixada (mol. $\mathrm{L}^{-1}$ )

$\begin{array}{ll}1,3 & 0,52 \\ 2,0 & 0,51\end{array}$


Na titulação das soluções de ácido bórico com solução padrão de ácido sulfúrico o frasco de menor volume apresentou concentração de amônia fixada pouco superior ao frasco de maior volume, não sendo conclusiva a influência desse parâmetro no aumento da volatilização da amônia.

\subsubsection{Influência da quantidade de cama de frango}

Fizeram-se experimentos em frascos com capacidade de 1,3 $\mathrm{L}$ contendo quantidades variadas de cama de frango e concentração de $9 \%$ de carbonato de sódio. Os resultados são apresentados na TAB. 21.

TABELA 21 - Relação entre as diferentes quantidades de cama de frango e as concentrações de amônia fixadas durante 19 dias

Quantidade de cama de frango (g) Concentração de amônia fixada (mol.. $\left.\mathrm{L}^{-1}\right)$

$\begin{array}{ll}25 & 0,55 \\ 50 & 0,59 \\ 75 & 0,61 \\ 100 & 0,61\end{array}$

As quantidades de 75 e de 100 gramas apresentaram as maiores concentrações de amônia, ou seja, 0,61 mol. $\mathrm{L}^{-1}$. Quanto maior a quantidade de cama de frango incubada maior a concentração de amônia fixada.

\subsubsection{Influência da adição de água}

Fizeram-se testes para verificar a influência da adição de água à cama de frango. A concentração de carbonato de sódio foi de $30 \%$. Os resultados estão apresentados na TAB. 22. 
TABELA 22 - Volume de água adicionado à $100 \mathrm{~g}$ de cama de frango e concentração de amônia fixada durante 19 dias

Volume de água adicionado $(\mathrm{mL}) \quad$ Concentração de amônia fixada $\left(m o l . \mathrm{L}^{-1}\right)$

$10 \quad 0,65$

O frasco contendo 100 gramas de cama de frango e $10 \mathrm{~mL}$ de água apresentou a maior concentração de amônia fixada em solução de ácido bórico. Em relação ao frasco contendo $10 \mathrm{~mL}$ de água, todos os outros apresentaram decréscimos nas concentrações de amônia fixada.

Quanto maior o volume de água adicionado à cama de frango menor a concentração de amônia fixada. Esse decréscimo pode ser explicado pela formação do composto iônico, amônio, com a água, diminuindo a quantidade de amônia disponível a ser volatilizada [82]. Outra explicação deve-se ao fato de a velocidade das atividades microbianas e enzimáticas serem reduzidas ou encerradas devido à escassez de oxigênio [9].

\subsubsection{Experimentos com a excreta}

\subsubsection{Influência do pH - concentração de carbonato de sódio}

Os resultados do experimento utilizando-se diferentes quantidades de carbonato de sódio adicionadas a $100 \mathrm{~g}$ de excreta encontram-se na FIG. 23. 


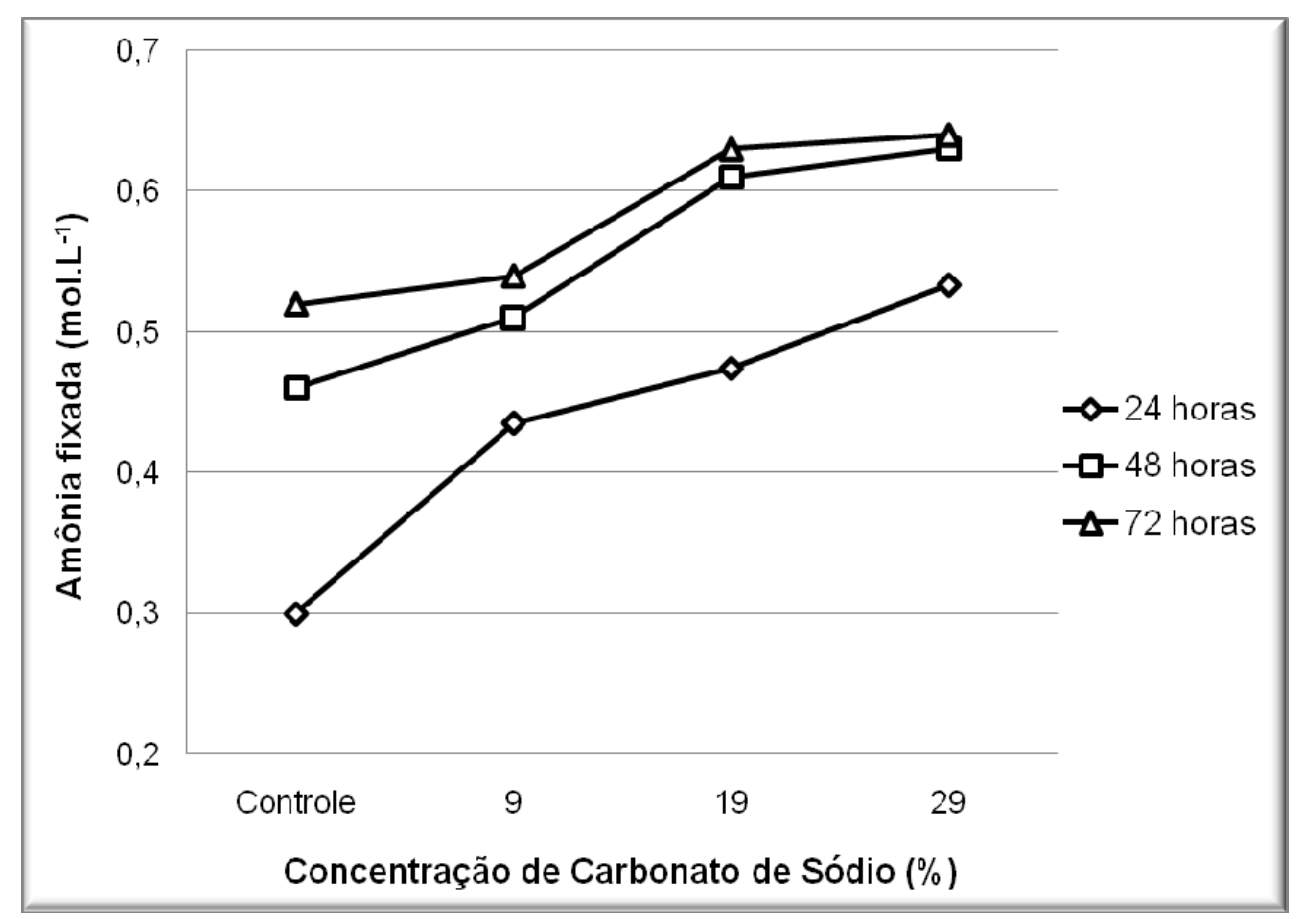

FIGURA 23 - Concentrações de carbonato de sódio e concentração de amônia fixada durante 24, 48 e 72 horas de incubação

Em todas as leituras foi possível observar um aumento da concentração de amônia fixada conforme se aumentava a quantidade de carbonato de sódio adicionada à excreta. Pode-se explicar este comportamento, pois a adição do carbonato de sódio ocasiona um aumento do $\mathrm{pH}$, favorecendo a ação das enzimas microbianas na degradação do ácido úrico. $\mathrm{Na}$ TAB. 23 são apresentados os valores de $\mathrm{pH}$ da excreta ao final do experimento. 
TABELA 23 - Valores de pH da excreta incubada nos frascos com diferentes concentrações de carbonato de sódio

Concentração de Carbonato de Sódio

$(\%)$

$\begin{array}{cc}\text { Controle } & 9,50 \\ 9 & 10,07 \\ 19 & 10,44 \\ 29 & 10,48\end{array}$

$\mathrm{pH}$ da excreta

9,50

(20)

\subsubsection{Influência do volume do frasco}

Os resultados dos experimentos utilizando-se frascos de diferentes volumes e concentração de $9 \%$ de carbonato de sódio podem ser visualizados na TAB. 24.

TABELA 24 - Frascos com diferentes volumes e concentração de amônia fixada durante 24,48 e 72 horas de incubação

Volume do frasco

(L)
1,3

2,0 Concentração de amônia fixada (mol.L $\left.{ }^{-1}\right)$

\begin{tabular}{cccc}
\cline { 2 - 4 }$(\mathrm{L})$ & 24 horas & 48 horas & 72 horas \\
\hline 1,3 & 0,39 & 0,46 & 0,49 \\
2,0 & 0,37 & 0,42 & 0,53 \\
\hline
\end{tabular}

A concentração de amônia fixada, nos experimentos com a excreta, foi pouco maior no frasco de capacidade de 1,3 L nas leituras de 24 e 48 horas, porém, na leitura de 72 horas a concentração de amônia fixada foi maior no frasco de $2,0 \mathrm{~L}$. 
Os resultados dos experimentos que tiveram como objetivo verificar a influência do volume do frasco na volatilização da amônia proveniente da cama de frango e/ou da excreta permitem constatar que a variação desse parâmetro não demonstrou diferenças significativas para ser escolhido como uma variável.

\subsubsection{Influência da quantidade de excreta}

Diferentes quantidades de excreta foram adicionadas a frascos com capacidade de 1,3 L. A concentração de carbonato de sódio empregada foi a de 9\%. Os resultados são apresentados na TAB. 25.

TABELA 25 - Diferentes quantidades de excreta em relação à concentração de amônia fixada durante 24, 48 e 72 horas de incubação

\begin{tabular}{cccc}
\hline \multirow{2}{*}{$\begin{array}{c}\text { Quantidade de } \\
\text { excreta }(\mathrm{g})\end{array}$} & \multicolumn{3}{c}{ Concentração de amônia fixada $\left(\mathrm{mol}_{\mathrm{L}} \mathrm{L}^{-1}\right)$} \\
\cline { 2 - 4 } & 24 horas & 48 horas & 72 horas \\
\hline 25 & 0,35 & 0,39 & 0,44 \\
50 & 0,40 & 0,43 & 0,51 \\
75 & 0,36 & 0,41 & 0,51 \\
100 & 0,39 & 0,46 & 0,49 \\
\hline
\end{tabular}

A concentração de amônia fixada na quantidade de $25 \mathrm{~g}$ de excreta foi menor em todas as leituras quando comparada com as demais. Resultados similares foram obtidos em todas as leituras, não sendo conclusiva a influência da variação da quantidade de excreta em um determinado volume no aumento ou aceleração da volatilização da amônia. 


\subsubsection{Influência do tempo de acúmulo de resíduos}

As coletas de excreta foram realizadas em diferentes datas e em diferentes tempos de acúmulo. A concentração de carbonato de sódio empregada foi de $9 \%$. Os resultados estão apresentados na TAB. 26.

TABELA 26 - Diferentes tempos de acúmulo de excreta e concentração de amônia fixada durante 24, 48 e 72 horas de incubação

\begin{tabular}{cccc}
\hline \multirow{2}{*}{$\begin{array}{c}\text { Acúmulo de excretas } \\
\text { (dias) }\end{array}$} & \multicolumn{3}{c}{ Concentração de amônia fixada $\left(\mathrm{mol}^{-\mathrm{L}^{-1}}\right)$} \\
\cline { 2 - 4 } & 24 horas & 48 horas & 72 horas \\
\hline 2 & 0,39 & 0,46 & 0,49 \\
6 & 0,44 & 0,51 & 0,54 \\
\hline
\end{tabular}

Em todas as leituras, 24, 48 e 72 horas, a concentração de amônia fixada mol. $\mathrm{L}^{-1}$ foi maior nas amostras de excreta coletadas no sexto dia de acúmulo. $\mathrm{O}$ teor de nitrogênio disponível das excretas aumenta com o passar dos dias, o acúmulo deste material orgânico, acarreta em uma maior volatilização de amônia.

\subsubsection{Influência da areia}

A influência da quantidade de areia na volatilização de amônia foi estudada utilizando-se um kit analisador do nível de amônia em aviários. Na TAB. 27 são apresentadas as concentrações de amônia em ppm. 
TABELA 27 - Diferentes quantidades de areia adicionada a $100 \mathrm{~g}$ de excreta e concentração de amônia fixada durante 7 dias de incubação

\begin{tabular}{cc}
\hline Quantidade de areia $(\mathrm{g})$ & Concentração de amônia (ppm) \\
\hline Controle & 350 \\
10 & 175 \\
20 & 175 \\
30 & 85 \\
40 & 0 \\
\hline
\end{tabular}

A diferença de concentração de amônia, de acordo com cartela colorimétrica, foi evidente entre o controle e o frasco contendo $40 \mathrm{~g}$ de areia. A intensidade do tom de azul da solução foi decrescendo conforme o aumento da quantidade de areia e na maior quantidade testada a solução da cubeta, após 10 minutos, ficou incolor. Foi possível notar, em nossos experimentos, que a adição de areia na excreta diminuiu a quantidade de amônia volatilizada.

\subsubsection{Influência dos tipos de ração}

A volatilização de amônia proveniente da excreta das aves alimentadas com ração comercial e da excreta das aves alimentadas com ração teste foi comparada. Esses resultados podem ser visualizados na TAB. 28. 
TABELA 28 - Comparação entre os diferentes tipos de ração (com diferentes teores de nitrogênio) e concentração de amônia fixada durante 8 dias de incubação

Diferentes tipos de ração

Concentração de amônia fixada

$$
\text { (mol.L }{ }^{-1} \text { ) }
$$

Ração comercial

0,46

Ração em teste

0,57

A excreta das aves alimentadas com a ração teste, com maior teor de proteína bruta e nitrogênio, apresentou maior concentração de amônia fixada.

Parte do nitrogênio contido na ração é absorvido pelo organismo e parte é excretado pela ave. Desse nitrogênio contido nas excretas, até $50 \%$ pode ser volatilizado na forma de amônia pela ação das bactérias [72].

Em excretas nitrogenadas, os microorganismos rapidamente usam o limitado suprimento de oxigênio fazendo com que o restante se torne anaeróbico. Além disso, as excretas nitrogenadas favorecem a produção de amônia [79].

A quantidade de nitrogênio, determinada pela análise elementar $\mathrm{CHN}$ das excretas proveniente das aves alimentadas com a ração comercial e com a ração teste, mostrada na TAB. 9, comprovam estes resultados.

\subsubsection{Influência da ação da enzima urease do feijão-de-porco}

\subsubsection{Confirmação da presença da enzima urease}

Para verificar a presença da enzima urease no extrato de feijão-de-porco e sua ação na hidrólise da uréia, uma solução de uréia foi preparada.

Tanto $\circ \mathrm{pH}$ da solução de uréia como o do extrato de feijão foi igual a 6 , indicando um caráter ligeiramente ácido. 
À solução de uréia foram adicionados $20 \mathrm{~mL}$ de extrato do feijão. Ao se adicionar o extrato à solução de uréia o valor do $\mathrm{pH}$ aumentou para 9,0, constatando-se o caráter alcalino, indicando, assim, a formação de amônia proveniente da hidrólise da uréia pela enzima urease contida no extrato de feijãode-porco.

Na FIG. 24 são apresentadas imagens dos tubos de ensaio contendo o extrato de feijão-de-porco, a solução de uréia e o extrato de feijão-de-porco mais a solução de uréia e seus respectivos valores de $\mathrm{pH}$ indicados pelo papel indicador de $\mathrm{pH}$.

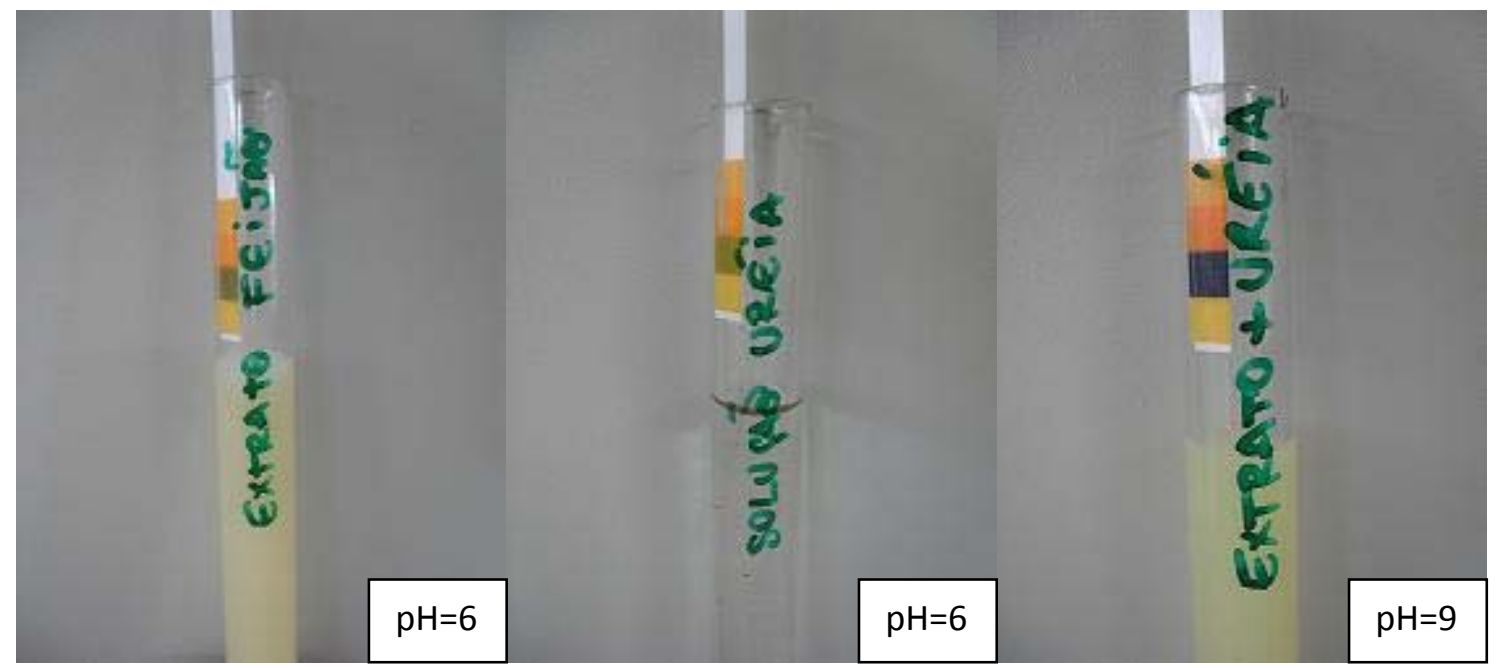

(a)

(b)

(c)

FIGURA 24 - Tubos de ensaio contendo extrato de feijão-de-porco (a); solução de uréia (b); extrato de feijão-de-porco + solução de uréia (c) e seus respectivos valores de $\mathrm{pH}$

$\mathrm{Na}$ adição do indicador fenolftaleína no tubo de ensaio contendo a solução de uréia e o extrato do feijão, a coloração da solução tornou-se rosa indicando a alcalinidade do meio (FIG. 25). 


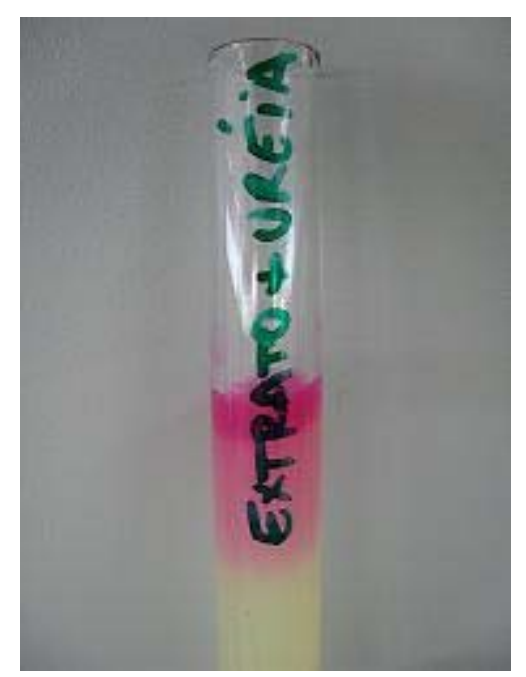

FIGURA 25 - Tubo de ensaio contendo extrato de feijão-de-porco e solução de uréia. A coloração rosa adquirida após a adição de fenolftaleína indica o caráter básico da solução

\subsection{Solução de uréia e extrato de feijão-de-porco}

O resultado do experimento para verificar a volatilização e a fixação da amônia formada a partir da hidrólise da uréia pela enzima urease está apresentado na TAB. 29.

TABELA 29 - Concentração de amônia fixada proveniente da solução de uréia com o extrato de feijão-de-porco

\begin{tabular}{cc}
\hline Extrato e solução de uréia & Concentração de amônia fixada (mol.L $\left.{ }^{-1}\right)$ \\
\hline $50 \mathrm{~mL}$ solução uréia $(10 \%)+50 \mathrm{~mL}$ & 1,09 \\
extrato de feijão-de-porco & \\
\hline
\end{tabular}

A volatilização da amônia formada na hidrólise da uréia pela enzima urease foi confirmada neste ensaio utilizando-se uma solução de uréia incubada junto ao extrato de feijão-de-porco. A amônia formada foi fixada na solução de ácido bórico e sua concentração determinada por titulação. 


\subsection{Influência do extrato de feijão-de-porco}

Diferentes volumes de extrato de feijão-de-porco foram adicionados à excreta para verificar a influência da enzima urease proveniente deste feijão na volatilização da amônia. Os resultados apresentados na FIG. 26 são referentes ao extrato de feijão-de-porco obtido com o emprego da primeira metodologia.

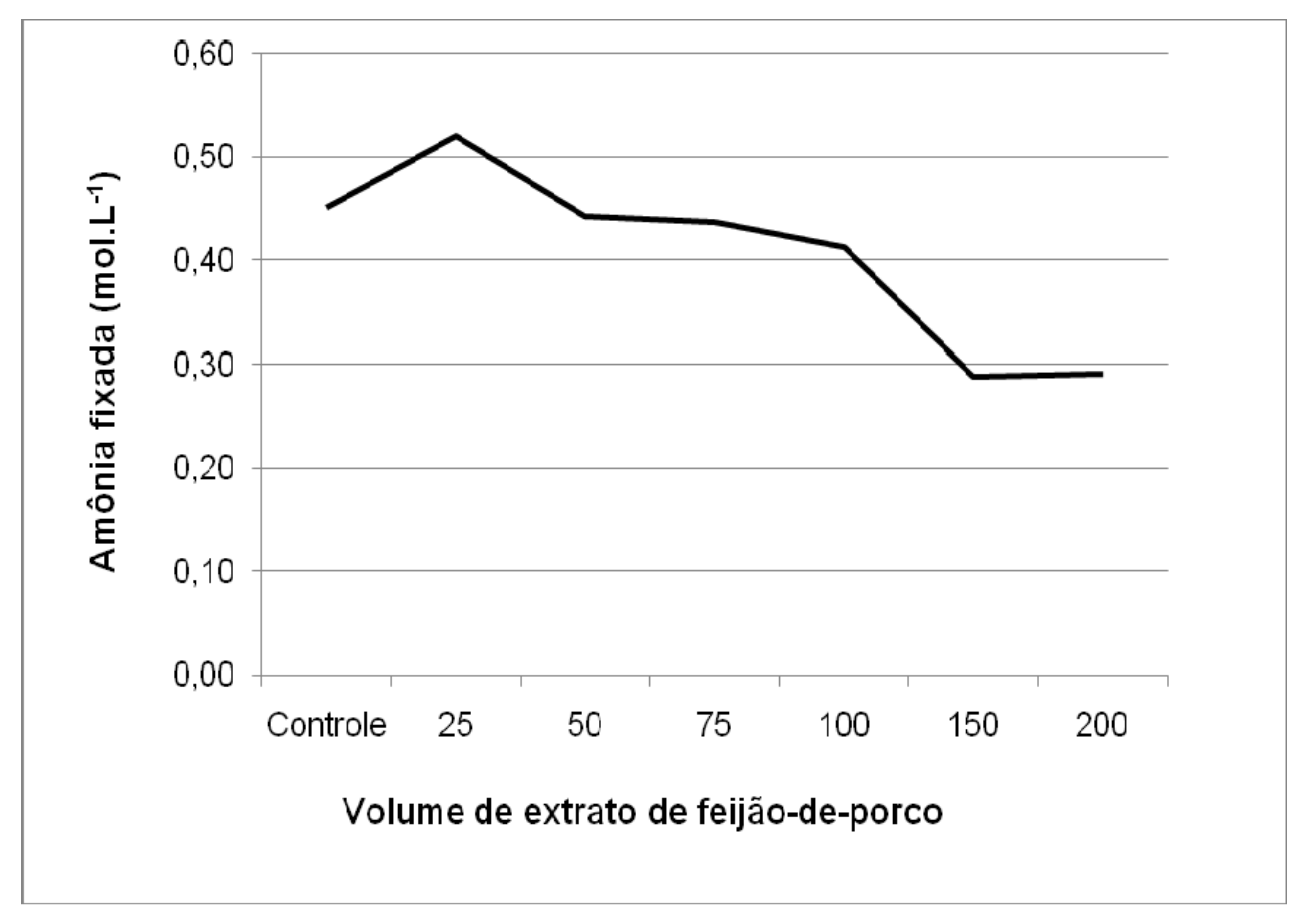

FIGURA 26 - Volume de extrato de feijão-de-porco (primeira metodologia) adicionado a $100 \mathrm{~g}$ de excreta e concentração de amônia fixada durante 7 dias de incubação

Quando comparado ao controle, a adição de $25 \mathrm{~mL}$ de extrato de feijão-deporco à $100 \mathrm{~g}$ de excreta apresentou um aumento de $0,07 \mathrm{~mol} \cdot \mathrm{L}^{-1}$ na concentração de amônia fixada.

Para os volumes de 50, 75 e $100 \mathrm{~mL}$ de extrato de feijão as concentrações de amônia fixada foram similares ao controle e nos maiores volumes de extrato de feijão adicionados à excreta, 150 e $200 \mathrm{~mL}$ ocorreu um decréscimo da concentração de amônia fixada. O extrato de feijão-de-porco apresentou valor de pH 6 e a volatilização da amônia proveniente da excreta foi favorecida em valores de $\mathrm{pH}$ acima de 8 . $\mathrm{O}$ caráter ligeiramente ácido do extrato de feijão e o aumento 
da umidade devido à quantidade de água contida no extrato de feijão podem ter inibido a volatilização da amônia.

Os resultados dos experimentos com o extrato de feijão obtido com o emprego da segunda metodologia para a extração da enzima urease estão apresentados na TAB. 30. O tempo de incubação foi de 7 dias.

TABELA 30 - Diferentes volumes de extrato de feijão-de-porco (segunda metodologia) e concentração de amônia fixada

Volume de extrato de feijão-de-porco

Concentração de amônia fixada (mol. $\mathrm{L}^{-1}$ )

\section{Controle}

50

100
0,45

0,37

0,36

As concentrações de amônia fixada nos experimentos com o extrato do feijão obtido com o emprego da segunda metodologia para a extração da enzima urease foram inferiores às concentrações de amônia fixada com o extrato do feijão obtido com o emprego da primeira metodologia. A comparação desses resultados pode ser visualizada na TAB. 31 .

TABELA 31 - Comparação entre as diferentes metodologias empregadas para a extração da enzima urease do feijão-de-porco

\begin{tabular}{ccc}
\hline \multirow{2}{*}{$\begin{array}{c}\text { Volume de extrato de } \\
\text { feijão-de-porco }(\mathrm{mL})\end{array}$} & \multicolumn{2}{c}{ Concentração de amônia fixada $\left(\mathrm{mol}_{\mathrm{L}} \mathrm{L}^{-1}\right)$} \\
\cline { 2 - 3 } & Primeira metodologia & Segunda metodologia \\
\hline 50 & 0,44 & 0,37 \\
100 & 0,41 & 0,36 \\
\hline
\end{tabular}


Os resultados da adição do volume de 50 e $100 \mathrm{~mL}$ de extrato de feijão-deporco da primeira metodologia foram maiores do que o da segunda indicando ser mais eficiente a extração da enzima urease quando o feijão-de-porco é triturado antes da adição de água.

\subsection{Influência da adição de feijão-de-porco triturado}

Os resultados dos experimentos utilizando o feijão triturado resultante da filtragem a vácuo estão apresentados na TAB. 32. As quantidades de 50 e 100 gramas de feijão-de-porco foram adicionadas a $100 \mathrm{~g}$ de excreta. $\mathrm{O}$ tempo de incubação foi de 7 dias.

TABELA 32 - Quantidade de feijão-de-porco triturado e concentração de amônia fixada

Quantidade de feijão-de-porco

triturado $(g)$

Concentração de amônia fixada $\left(m o l \cdot L^{-1}\right)$

Controle

50

100
0,45

0,34

0,34

A adição das quantidades de 50 e $100 \mathrm{~g}$ de feijão-de-porco após a retirada do extrato contendo a enzima urease inibiu a volatilização da amônia quando comparado ao controle, sugerindo que a enzima urease já não se encontra disponível.

Todos os ensaios foram realizados no mesmo período. A temperatura nos 7 dias de incubação foi em torno de $20^{\circ} \mathrm{C}$. A baixa temperatura não favoreceu a atividade microbiana para a decomposição da amônia.

A decomposição microbiana da amônia ocorre em cinco etapas enzimáticas, sendo a última a hidrólise da uréia em amônia [57]. Acredita-se que as etapas anteriores, até a chegada na uréia, foram diminuídas pelo caráter ligeiramente ácido do extrato de feijão-de-porco. 
Um estudo aprofundado sobre a enzima urease proveniente do feijão-deporco e a sua ação seria necessário para uma melhor interpretação dos resultados.

A aplicação desse parâmetro em larga escala não seria conveniente tendo em vista o processo para a extração da enzima urease.

\subsubsection{Influência da temperatura}

Os resultados do experimento verificando a influência da temperatura na volatilização da amônia são apresentados na FIG. 27. Frascos contendo $100 \mathrm{~g}$ de excreta foram mantidos em diferentes temperaturas. As temperaturas de incubação foram de 20 (controle), 30,50 e $70^{\circ} \mathrm{C}$.

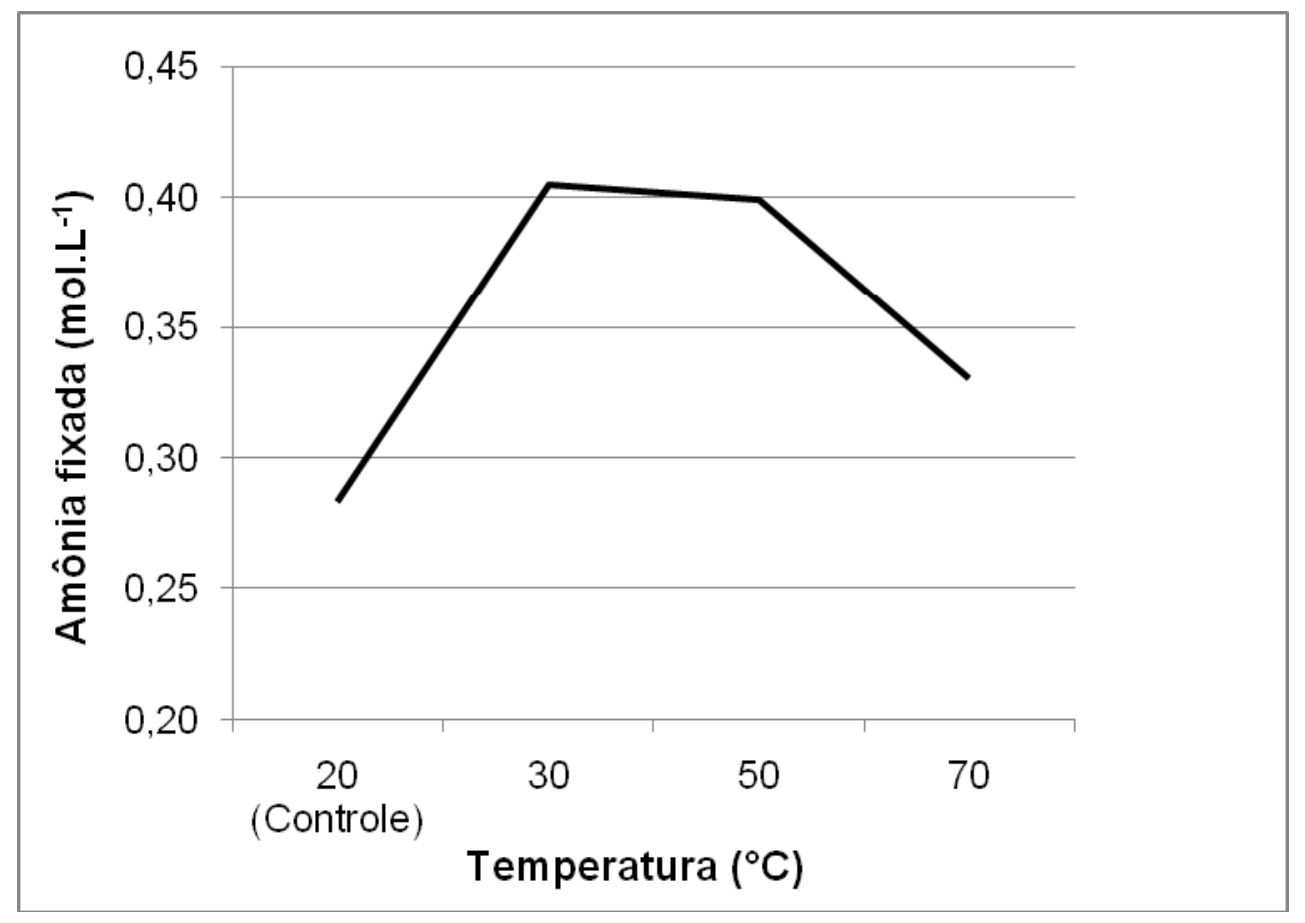

FIGURA 27 - Concentração de amônia fixada durante 24 horas em diferentes temperaturas de incubação

A concentração de amônia fixada na temperatura de $30^{\circ} \mathrm{C}$ aumentou 0,13 mol. $L^{-1}$ em relação ao controle e praticamente se manteve na temperatura de $50^{\circ} \mathrm{C}$. Quando o frasco foi incubado a temperatura de $70^{\circ} \mathrm{C}$ houve um decréscimo em relação às temperaturas de 30 e $50^{\circ} \mathrm{C}$, mesmo assim na temperatura de $70^{\circ} \mathrm{C}$ 
a concentração de amônia fixada foi maior do que a determinada no frasco controle.

Os resultados deste experimento confirmam a influência positiva da temperatura na volatilização da amônia. Podendo-se afirmar que a temperatura considerada propícia para o desenvolvimento bacteriano está entre 30 e $50^{\circ} \mathrm{C}$, pois quando a temperatura foi elevada para $70^{\circ} \mathrm{C}$ a concentração de amônia fixada diminuiu.

\subsubsection{Influência da temperatura e do pH - concentração de carbonato de sódio}

Os resultados da verificação da influência da temperatura junto à adição de carbonato de sódio na volatilização da amônia são apresentados na TAB. 33. Um frasco teste contendo $100 \mathrm{~g}$ de excreta e $39 \mathrm{~g}$ de carbonato de sódio, obtendo-se a concentração de $39 \%$, foi incubado pelo período de 24 horas em estufa a $40^{\circ} \mathrm{C}$.

TABELA 33 - Temperatura em que o frasco teste foi incubado, concentração de carbonato de sódio e concentração de amônia fixada em 24 horas
Temperatura $\left({ }^{\circ} \mathrm{C}\right) /$ Concentração de carbonato de sódio (\%)
Concentração de amônia fixada (mol.L $\left.{ }^{-1}\right)$

Controle

0,28

$40 / 39$

0,57

No período de 24 horas, a manipulação dos parâmetros temperatura e pH dobrou a concentração de amônia fixada quando comparada à concentração determinada no frasco controle.

Com base nesses resultados é possível afirmar que entre os parâmetros estudados, a temperatura e pH foram os mais eficazes para acelerar a volatilização da amônia proveniente da excreta e podem ser manipulados em grandes quantidades de dejetos. 


\subsection{Testes com o reformador de amônia}

O gás proveniente da reforma da solução de hidróxido de amônio foi analisado, qualitativamente, por meio da técnica de cromatografia a gás. Os cromatogramas apresentaram dois picos, os quais foram identificados como hidrogênio e nitrogênio. Na FIG. 28 são apresentados os dados de três injeções do gás de reforma no cromatógrafo.
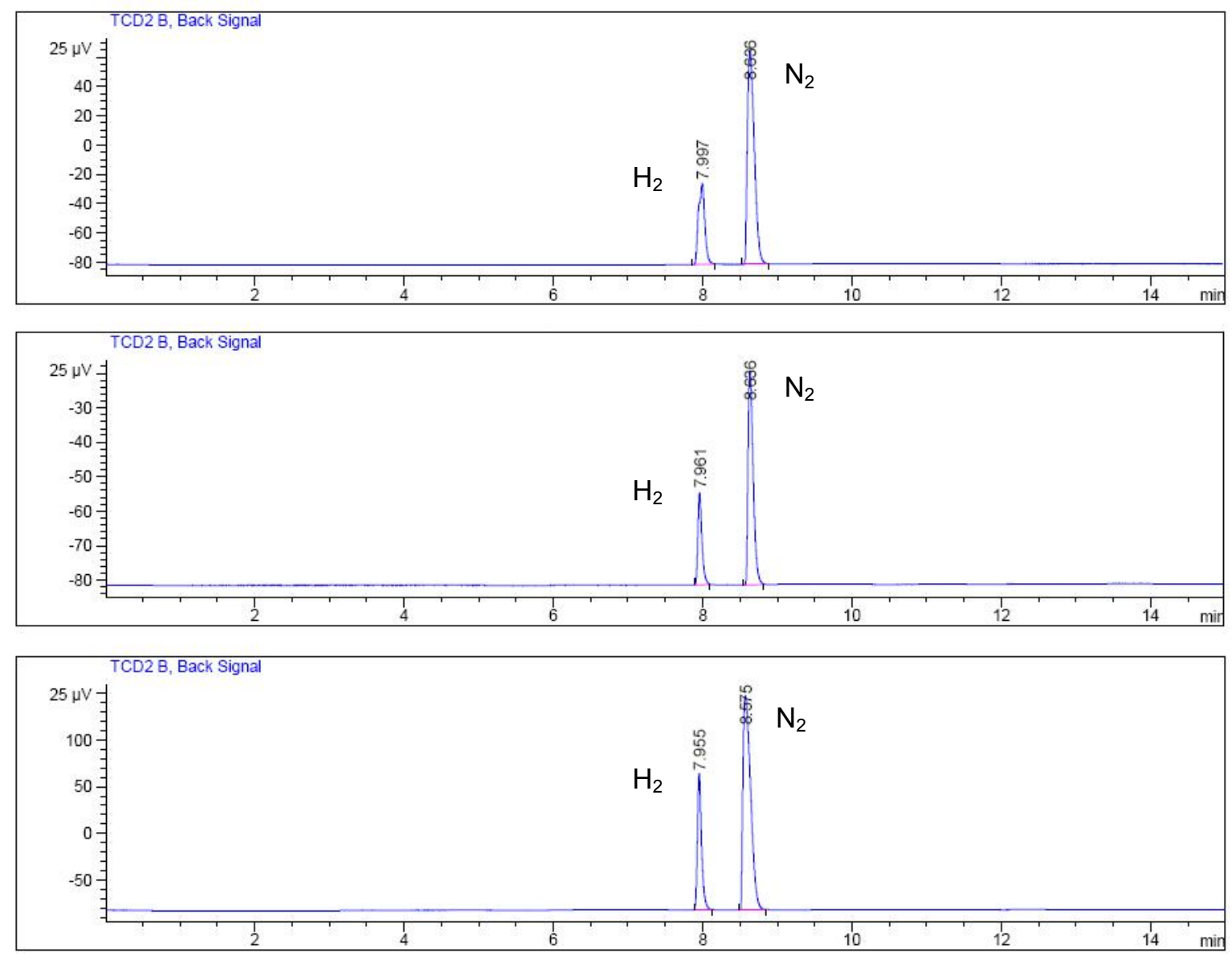

FIGURA 28 - Cromatogramas das análises do gás de reforma do hidróxido de amônio

A solução de hidróxido de amônio submetida ao processo de reforma resultou em um gás contendo hidrogênio e nitrogênio. Essa solução também pode ser obtida por meio da fixação da amônia liberada das excretas nitrogenadas das aves em água. O estudo do processo para a aceleração da geração de amônia 
pode ter uma utilidade prática com a utilização do hidrogênio obtido em um sistema de células a combustível para a produção de eletricidade. 


\section{CONCLUSÕES}

Os resultados obtidos nos experimentos com a cama de frango e com a excreta permitem concluir que a manipulação dos seguintes parâmetros aumentaram a emissão de amônia:

- $\mathrm{pH}$ - o aumento do pH por meio da adição de carbonato de sódio;

- Teor de nitrogênio - excreta das aves alimentadas com ração contendo maior teor de proteína bruta;

- Tempo de criação, idade das aves e acúmulo - com o passar dos dias o teor de nitrogênio dos resíduos aumentam;

- Enzima urease - o volume de $25 \mathrm{~mL}$ de extrato de feijão-de-porco;

- Temperatura - entre 30 e $50^{\circ} \mathrm{C}$; e

- Temperatura $+\mathrm{pH}-40^{\circ} \mathrm{C}$ e $39 \%$ de carbonato de sódio dobraram a concentração de amônia fixada.

As adições de diferentes quantidades de areia na excreta e de diferentes volumes de água na cama de frango diminuíram a emissão de amônia. A variação da quantidade de material (cama ou excreta) e do volume do frasco utilizado como câmara incubadora não demonstraram alterações significativas para serem escolhidos como uma variável.

Comparando-se o material utilizado, a excreta proveniente da criação de galinhas poedeiras apresentou maior quantidade de amônia fixada do que a cama de frango, composta, além da excreta, de maravalha de madeira.

A manipulação simultânea dos parâmetros temperatura e $\mathrm{pH}$ mostrou-se mais eficaz na aceleração da volatilização de amônia e são de fácil aplicação em grandes quantidades de resíduos.

O desenvolvimento da tecnologia do uso da amônia sintética para a obtenção de hidrogênio abre caminhos para novas pesquisas utilizando amônia proveniente de outras fontes, como por exemplo, a resultante da decomposição microbiana da cama de frango.

Devido à grande quantidade de cama de frango e de excretas resultantes dos processos de produção, o reaproveitamento dos resíduos avícolas para a 
obtenção de amônia se faz necessário para melhorar a qualidade do meio ambiente local. A possibilidade do aumento da emissão de amônia, verificada nesse trabalho e a sua utilização em um sistema geração de amônia-produção de hidrogênio-célula a combustível, poderá produzir eletricidade no próprio empreendimento, reduzindo os gastos das granjas e destinando adequadamente esses resíduos. 


\section{REFERÊNCIAS BIBLIOGRÁFICAS}

[1] SOUZA, M. M. V. M. Tecnologia do Hidrogênio. Rio de Janeiro: Synergia Editora, 2009.

[2] BARBIR, F. PEM Fuel Cells: Theory and Practice. United States of America: Elsevier Academic Press, 2005.

[3] LINARDI, M. Introdução à Ciência e Tecnologia de Células a Combustível. São Paulo: Artliber Editora. p.63, 2010.

[4] CHRISTENSEN, C. H.; JOHANNESSEN, T.; SØRENSEN, R. Z.; NØRSKOV, J. K. Towards an ammonia-mediated hydrogen economy? Catalysis Today, v. 111 , p. 140-144, 2006.

[5] VYJAYANTHI, A.; PALANKI, S.; WEST, K. N. Analysis of ammonia decomposition reactor to generate hydrogen for fuel cell applications. Journal of Power Sources, v. 195, p. 829-833, 2010.

[6] CHRISTENSEN, C. H.; SØRENSEN, R. Z.; JOHANNESSEN, T.; QUAADE, U.; HONKALA, K.; ELMØE, T. D.; KØHLER, R.; NØRSKOV, J. Metal ammine complexes for hydrogen storage. Journal of Materials Chemistry, v. 25, p. 41064108, 2005.

[7] DONATO, D. C. Z.; GANDRA, E. R. S.; GARCIA, P. D. S. R.; REIS, C. B. M.; GAMEIRO, A. H. A questão da qualidade no sistema agroindustrial do ovo. In: SOBER $47^{\circ}$ Congresso - Sociedade Brasileira de Economia, Administração e Sociologia Rural, Porto Alegre, 2009.

[8] OVIEDO-RONDÓN, E. O. Tecnologias para mitigar o impacto ambiental da produção de frangos de corte. Revista Brasileira de Zootecnia, v. 37, p. 239$252,2008$.

[9] LIU, Z.; WANG, L.; BEASLEY, D. B. A review of emission models of ammonia released from broiler houses. American Society of Agricultural and Biological Engineers ASABE, Paper No 064101, Portland, p. 1-17, 2006.

[10] SCHEFFERLE, H. E. The Microbiology of Built Up Poultry Litter. Journal of Applied Microbiology, v. 28, n. 3, p. 403-411, 1965. 
[11] IPCC - INTERGOVERNMENTAL PANEL ON CLIMATE CHANGE. Stabilization of atmospheric greenhouse gases: Physical, biological and sócio-economic implications. Geneva, Switzerland, 1997.

[12] EPA - UNITED STATES ENVIRONMENTAL PROTECTION AGENCY. Climate Change Indicators in the United States. Disponível em: http://www.epa.gov/climatechange/indicators.html. Acessado em: 05 julho, 2010.

[13] EPE - EMPRESA DE PESQUISA ENERGÉTICA. Balanço Energético Nacional 2010 - Ano base 2009: Resultados Preliminares. Rio de Janeiro: EPE, 2010.

[14] MAPA - MINISTÉRIO DA AGRICULTURA, PECUÁRIA E ABASTECIMENTO, SECRETARIA DE PRODUÇÃO E AGROENERGIA. Plano Nacional de Agroenergia 2006-2011. Brasília: Embrapa Informação Tecnológica, 2006.

[15] MME - MINISTÉRIO DE MINAS E ENERGIA E EPE - EMPRESA DE PESQUISA ENERGÉTICA. Plano Nacional de Energia 2030 - Eficiência Energética. v. 11. Brasília: MME: EPE, 2007.

[16] MME - MINISTÉRIO DE MINAS E ENERGIA. Tecnologias de energias renováveis: sistemas híbridos, pequenos aproveitamentos hidroelétricos, combustão e gaseificação de biomassa sólida, biodiesel e óleo vegetal in natura. Brasília: Ministério de Minas e Energia, 2008.

[17] ALDABÓ, R. Célula a Combustível a Hidrogênio: fonte de energia da nova era. São Paulo: Artliber Editora Ltda, 2004.

[18] GOMES NETO, E. H. Hidrogênio, Evoluir Sem Poluir: a era do hidrogênio, das energias renováveis e das células a combustível. Curitiba: Brasil H2 Fuel Cell Energy, 2005.

[19] VIELSTICH, W.; LAMM, A.; GASTEIGER, H. A. Handbook of fuel cells Fundamentals, technology and applications. Inglaterra: John Wiley \& Sons Ltda, v. 1, 2003. apud LINARDI, M. Introdução à Ciência e Tecnologia de Células a Combustível. São Paulo: Artliber Editora, p. 63, 2010.

[20] WENDT, H.; GOTZ, M.; LINARDI, M. Tecnologia de células a combustível. Química Nova, v. 23, n. 4, 2000. 
[21] CGEE - CENTRO DE GESTÃO E ESTUDOS ESTRATÉGICOS. Programa Brasileiro de células a combustível. 2009.

[22] VTT TECHNICAL RESEARCH CENTRE OF FINLAND. Energy visions 2030 for Finland, Finland: Editora Helsinki, 2001. apud ALANNE, K.; SAARI, A. Distributed energy generation and sustainable development. Renewable and Sustainable Energy Reviews, p. 539-558, 2006.

[23] RIFKIN, J. A. Economia do hidrogênio. São Paulo: M. Books do Brasil Editora Ltda, 2003.

[24] MELLOR, J. W. Química Inorgânica Moderna. Porto Alegre: Editora Globo, 1.ed., 1967.

[25] AZEVEdo, M. G.; FERRAZ, H. C.; SALIM, V. M., BORGES, C. P. Preparo de membranas de carbono para separação de hidrogênio. Revista Matéria, $v$. 11, n. 4, p. 372-378, 2006.

[26] ARMOR, J. N. The multiple roles for catalysis in the production of $\mathbf{H}_{2}$. Applied Catalysis A: General, v. 176, p. 159-176, 1999. apud SOUZA, M. M. V. M. Tecnologia do Hidrogênio. Rio de Janeiro: Synergia Editora. 2009.

[27] DAS, D. VEZIROĝLU, T. N. Hydrogen production by biological process: a survey of literature. International Journal of Hydrogen Energy, v. 26, p. 13-28, 2001.

[28] TICIANELLI, E. A.; CAMARA, G. A.; SANTOS, L. G. R. A. Eletrocatálise das reações de oxidação de hidrogênio e de redução de oxigênio. Química Nova, v. 28, n. 4, p. 664-669, 2005.

[29] AMPHLETT, J. C.; MANN, R. F.; PEPPLEY, B. A. On board hydrogen purification for steam reformation/PEM fuel cell vehicle power plants. International Journal of Hydrogen Energy, v. 21, n. 8, p. 673-678,1998.

[30] NEVES, C. F. C.; SCHVARTZMAN, M. M. A. M. Separação de $\mathrm{CO}_{2}$ por meio da tecnologia PSA. Química Nova, v. 28, n. 4, p. 622-628, 2005.

[31] ADHIKARI, S.; FERNANDO, S. Hydrogen membrane separation techniques. Industrial \& Engineering Chemistry Research, v. 45, n. 3, p. 875-881, 2006. 
[32] ABRÃO, A.; ALVARINHO, S. B.; SOUZA, H. R.; NUCCl, O. Processo para obtenção de hidrogênio por decomposição termocatalítica da amônia em reator de membrana, para aplicação em célula a combustível. In: Encontro sobre a Célula a combustível, São Paulo, 2003. 1 CD-ROM. Apresentação em Power Point.

[33] TAIZ, L.; ZEIGER, E. Fisiologia Vegetal. Sunderland, Massachusetts: Sinauer Associates Inc. Publishers, 3.ed., 78 p., 2006.

[34] CONN, E. E. Introdução a Bioquímica. São Paulo: Edgard Blucher, 525 p., 1980.

[35] ODUM, E. P. Ecologia. Rio de Janeiro: Guanabara Koogan S.A., 434 p., 1988.

[36] RAVEN, P. H.; EVERT, R. F; EICHHORN, S. E. Biologia Vegetal. Rio de Janeiro: Guanabara Koogan S.A., 6. ed., 906 p., 2001.

[37] OLIVEIRA, M. C.; ALMEIDA C. V.; ANDRADE D. O. et al. Teor de matéria seca, pH e amônia volatilizada da cama de frango tratada ou não com diferentes aditivos. Revista Brasileira de Zootecnia, v. 32, p. 951-954, 2003.

[38] BAIÃO, N. C. Quando o ambiente fica carregado. Revista Aves e Ovos, São Paulo, p. 20-22, 1996.

[39] JORGE, M. A.; MOUCHREK, E.; CARNEIRO, M. I. F. et al. Coliformes, umidade e produção de amônia em cinco tipos de cama de frango. Arquivo Brasileiro de Medicina Veterinária e Zootecnia, v. 48, p. 387-395, 1996. apud MIRAGLIOTTA, M. Y.; NAAS, I. A.; BARACHO, M.S, ARADAS, M. E. C. Qualidade do ar de dois sistemas produtivos de frangos de corte com ventilação e densidade diferenciadas - estudo de caso. Engenharia Agrícola Jaboticabal, v. 22, p.1-10, 2002.

[40] SØRENSEN, R. Z.; NIELSEN, L. J. E.; JENSEN, S.; HANSEN, O.; JOHANNESSEN, T.; QUAADE, U.; CHRISTENSEN, C. H. Catalytic ammonia decomposition: miniaturized production of $\mathrm{Co}_{\mathrm{x}}$-free hydrogen for fuel cells. Catalysis Communications, v. 6, p. 229-232, 2005. 
[41] ASSOCIAÇÃO BRASILEIRA DE NORMAS TÉCNICAS - ABNT: NR15 Atividades e Operações Insalubres: Agentes químicos cuja insalubridade é caracterizada por limite de tolerância e inspeção no local de trabalho. Rio de Janeiro, 1978.

[42] WERNER, A. Nobel Prize Lecture "On the constitution and configuration of higher-order compounds", 1913 apud CHRISTENSEN, C. H.; SØRENSEN, R. Z.; JOHANNESSEN, T.; QUAADE, U.; HONKALA, K.; ELMØE, T. D.; KØHLER, R.; NØRSKOV, J. Metal ammine complexes for hydrogen storage. Journal of Materials Chemistry, v. 25, p. 4106-4108, 2005.

[43] IBGE - INSTITUTO BRASILEIRO DE GEOGRAFIA E ESTATÍSTICA. Estatística da Produção Pecuária, junho 2010.

[44] BELUSSO, D.; HESPANHOL, A. N. A evolução da avicultura industrial brasileira e seus efeitos territoriais. Revista Percurso - NEMO. Maringá, v. 2, n. 1, p. 25-51, 2010.

[45] MIRAGLIOTTA, M. Y.; NAAS, I. A.; BARACHO, M. S., ARADAS, M. E. C. Qualidade do ar de dois sistemas produtivos de frangos de corte com ventilação e densidade diferenciadas - estudo de caso. Engenharia Agrícola, Jaboticabal, v. 22, p. 1-10, 2002.

[46] SANTOS, T. M. B.; LUCAS JÚNIOR, J. Balanço energético em galpão de frangos de corte. Engenharia Agrícola, Jaboticabal, v. 24, n. 1, p. 25-36, 2004.

[47] AUGUSTO, V. Z. K. Manejo de dejetos em granjas de postura comercial. Avicultura Industrial, n.5. 2005.

[48] ESALQ - Escola Superior de Agricultura "Luiz de Queiroz". Os animais exemplo de degradação da biomassa. Disponível em: www.esalq. usp.br/departamentos/lpv/download/Khatounian140-150.pdf Acessado em: 23 setembro 2010.

[49] MELOTTI, L.; LUCCI, C. S.; MORGULLIS, S. C. F. et al. Degrabilidade ruminal de camas de frangos pela técnica dos sacos de náilon in situ com bovinos. Brazilian Journal of Veterinary Research and Animal Science, v. 35, 1998. 
[50] HERNANDES, R.; CAZETTA, J. O.; MORAES, V. M. B. Frações Nitrogenadas, Glicídicas e Amônia liberada pela cama de frangos de corte em diferentes densidades e tempos de confinamento. Revista Brasileira de Zootecnia, v. 31, p. 1795-1802, 2002.

[51] EL BOUSHY, A.R.Y., VAN DER POEL, A.F.B. Poultry feed from waste: processing and use. London, UK, Chapman \& Hall, 1.ed., 1994. 438 p. apud SANTOS, E. C.; COTTA, J. T. B.; MUNIZ, J. A.; FONSECA, R. A.; TORRES, D. M. Avaliação de alguns materiais usados como cama sobre o desempenho de frangos de corte. Simpósio sobre Resíduos da Produção Avícola. 2000.

[52] ALBUQUERQUE, R. Desempenho de aves para corte criadas sobre cama de casca de vagem de feijão. Avicultura Industrial, v. 77, n. 935, p.13-16, 1987. apud MELOTTI, L.; LUCCI, C. S.; MORGULLIS, S. C. F. et al. Degrabilidade ruminal de camas de frangos pela técnica dos sacos de náilon in situ com bovinos. Brazilian Journal of Veterinary Research and Animal Science. v. 35, 1998.

[53] RITZ, C. W.; FAIRCHILD, B. D.; LACY, M. P. Litter Quality and Broiler Performance. Cooperative Extension Service/The University of Georgia College of Agricultural and Environmental Sciences, Georgia, Bulletin 1267 April, 2005.

[54] OLIVEIRA, M. D. L. Avaliação das fezes de galinhas poedeiras e de sua associação com o bagaço de cana-de-açúcar hidrolisado na alimentação de bovinos. 1991. Tese (Doutorado) - Faculdade de Ciências Agrárias e Veterinárias, Unesp, Jaboticabal,. apud AUGUSTO, V. Z. K. Caracterização quantitativa e qualitativa dos resíduos em sistemas de produção de ovos: compostagem e biodigestão anaeróbia. 2007. Dissertação (Mestrado) Faculdade de Ciências Agrárias e Veterinárias - Unesp, Jaboticabal.

[55] ORDOÑEZ, Y. M.; CASTILHO, J. G. C.; DUCH, E. S.; CASTELLANOS RUELAS, A. F. Contenido de algunos macro e microminerales en lãs deyecciones avícolas en Yucatan. Tecnologia Pecuária del México, Ciudad del México, v. 33 n. 2, p 100-104,1995. apud AUGUSTO, V. Z. K. Caracterização quantitativa e qualitativa dos resíduos em sistemas de produção de ovos: 
compostagem e biodigestão anaeróbia. 2007. Dissertação (Mestrado) Faculdade de Ciências Agrárias e Veterinárias - Unesp, Jaboticabal.

[56] AUGUSTO, V. Z. K. Caracterização quantitativa e qualitativa dos resíduos em sistemas de produção de ovos: compostagem e biodigestão anaeróbia. 2007. Dissertação (Mestrado) - Faculdade de Ciências Agrárias e Veterinárias - Unesp, Jaboticabal.

[57] KIM, W. K.; PATTERSON, P. H. Effect of minerals on activity of microbial uricase to reduce ammonia volatilization in poultry manure. Poultry Science Association, v. 82, p. 223-231, 2003.

[58] FELIX, E. P.; CARDOSO, A. A. Amônia $\left(\mathrm{NH}_{3}\right)$ atmosférica: fontes, transformação, sorvedouros e métodos de análise. Química Nova, v. 27, n. 1, p. 123-130, 2004.

[59] NI, J. Emission of carbon dioxide and ammonia from mechanically ventilated pig house. 1998. Tese (Doutorado). Catholic University of Leuven. apud LIU, Z.; WANG, L.; BEASLEY, D. B. A review of emission models of ammonia released from broiler houses. American Society of Agricultural and Biological Engineers ASABE, Paper No 064101, Portland, p. 1-17, 2006.

[60] HUTCHINGS, N.; FAGERLI, H.; ASMAN, W.; MISSELBROOK, T.; PINDER, R. W.; WEBB, J. Modeling and Regulating Ammonia Emissions. Proceedings of Workshop on Agricultural Air Quality. 2006 apud LIU, Z.; WANG, L.; BEASLEY, D. B. A review of emission models of ammonia released from broiler houses. American Society of Agricultural and Biological Engineers ASABE, Paper No 064101, Portland, p. 1-17, 2006.

[61] PINDER, R. W.; PEKNEY, N. J.; DAVIDSON, C. I.; ADAMS, P. J. A processbased model of ammonia emissions from dairy cows: improved temporal and spatial resolution. Atmospheric Environment, v. 38, n. 9, p. 1357-1365, 2004. apud LIU, Z.; WANG, L.; BEASLEY, D. B. A review of emission models of ammonia released from broiler houses. American Society of Agricultural and Biological Engineers ASABE, Paper No 064101, Portland, p. 1-17, 2006.

[62] ZHANG, R.; RUMSEY, T. R.; FADEL, J. G.; AROGO, J.; WANG, Z.; MANSELL, G. E.; XIN, H. A Process-Based Ammonia Emission Model for 
Confinement Animal Feeding Operations - Model Development. Technical paper, 2006. apud LIU, Z.; WANG, L.; BEASLEY, D. B. A review of emission models of ammonia released from broiler houses. American Society of Agricultural and Biological Engineers ASABE, Paper No 064101, Portland, p. 1-17, 2006.

[63] CARR, L. E.; WHEATON, F. W.; DOUGLAS, L. W. Empirical models to determine ammonia concentrations from broiler chicken litter. ASABE American Society of Agricultural and Biological Engineers, v. 33, n. 4, p. 13371342, 1990 apud LIU, Z.; WANG, L.; BEASLEY, D. B. A review of emission models of ammonia released from broiler houses. ASABE, Paper No 064101, Portland, p. 1-17, 2006.

[64] KEENER, H. M; ZHAO, L. Predicting $\mathbf{N H}_{3}$ Emissions from Manure $\mathbf{N}$ for Livestock Facilities and Storages: A Modified Mass Balance Approach. Proceedings of the Workshop on Agricultural Air Quality, 2006 apud LIU, Z.; WANG, L.; BEASLEY, D. B. A review of emission models of ammonia released from broiler houses. American Society of Agricultural and Biological Engineers ASABE, Paper No 064101, Portland, p. 1-17, 2006.

[65] SIEFERT, R. L; SCUDLARK, J. R.; POTTER, A. M.; SIMONSEN, K. A.; SAVIDGE, K. B. Characterization of atmospheric ammonia emissions from a commercial chicken house on the Delmarva Peninsula. Environmental Science Technology, v. 38, p. 2769-2778, 2004. apud LIU, Z.; WANG, L.; BEASLEY, D. B. A review of emission models of ammonia released from broiler houses. American Society of Agricultural and Biological Engineers ASABE, Paper No 064101, Portland, p. 1-17, 2006.

[66] KOHN, R. A.; DOU, Z.; FERGUSON, J. D.; BOSTON, R. C. A sensitivity analysis of nitrogen losses from dairy farms. Journal of Environmental Management, v. 50, p. 417-428, 1997 apud LIU, Z.; WANG, L.; BEASLEY, D. B. A review of emission models of ammonia released from broiler houses. American Society of Agricultural and Biological Engineers ASABE, Paper No 064101, Portland, p. 1-17, 2006.

[67] AVILA, V. S.; OliveIRA, U.; FIGUEIREDO, E. A. P.; COSTA, C. A. F.; ABREU, V. M. N.; ROSA, P. S. Avaliação de materiais alternativos em 
substituição a maravalha como cama de aviário. Revista Brasileira de Zootecnia, v. 37, n. 2, p. 273-277, 2008.

[68] OLIVEIRA, M. C.; BENTO, E. A.; CARVALHO, F. I.; RODRIGUES, S. M. M. R. Características da cama e desempenho de frangos de corte criados em diferentes densidades populacionais e tipo de cama. ARS Veterinária, Jaboticabal, v. 21, n. 3, p. 303-310, 2005.

[69] LIEN, R. J.; HESS, J. B.; CONNER, D. E.; WOOD, C. W.; SHELBY, R. A. Peanut hulls as a litter source for broiler breeder replacement pullets. Poultry Science Association, v. 74, n. 1, p. 41-46, 1998.

[70] ATAPATTU, N. S. B. M.; SENARATNA, D.; BELPAGODAGAMAGE, U. D. A. Comparison of Ammonia Emission Rates from Three Types of Broiler Litters. Poultry Science Association, v. 87, p. 2436-2440, 2008.

[71] ELWINGER, K.; SVENSSON, L. Effect of dietary protein content, litter and drinker types on ammonia emission from broiler house. Journal of Agricultural Engineering Research, v. 64, p. 197-208, 1996.

[72] SIMS, J. T.; WOLF, D. C. Poultry manure management: Agricultural and environmental issues. Advances in Agronomy, v. 52, p. 1-83, 1994. apud KIM, W. K.; PATTERSON, P. H. Effect of minerals on activity of microbial uricase to reduce ammonia volatilization in poultry manure. Poultry Science Association, v. 82, p. 223-231, 2003.

[73] NEME, R.; SAKOMURA, N. K.; OlIVEIRA, M. D. S.; LONGO, F. A.; FIGUEIREDO, A. N. Adição de gesso agrícola em três tipos de cama de aviário na fixação de nitrogênio e no desempenho de frango de corte. Ciência Rural, Santa Maria, v. 30, n. 4, p. 687-689, 2000.

[74] CARVALHO NETO, P. M. Efeitos da criação de frangos em alta densidade sobre a ambiência do galpão, o rendimento zootécnico, e a qualidade da carne. 2005. Dissertação (Mestrado) - Universidade Estadual de Campinas, Campinas.

[75] KUBENA, L. F.; REECE, F. N.; MAY, J. D. Nutritive properties of broiler excreta as influenced by environmental temperature, collection interval, age of broilers and diet. Poultry Science, v. 52, p. 1700-1703, 1973. apud 
HERNANDES, R.; CAZETTA, J. O.; MORAES, V. M. B. Frações Nitrogenadas, Glicídicas e Amônia liberada pela cama de frangos de corte em diferentes densidades e tempos de confinamento. Revista Brasileira de Zootecnia, v. 31, p. 1795-1802, 2002.

[76] REDWINE, J. S.; LACEY, R. E.; MUKHTAR, S.; CAREY, J. B. Concentration and Emissions of Ammonia and Particulate Matter in Tunnel - Ventilated Broiler Houses under Summer Conditions in Texas. American Society of Agricultural Engineers, v. 45, n. 4, p. 1101-1109, 2002.

[77] Qualidade da cama e sua importância na produção avícola. AGROLINK. Disponível em: http: //www.agrolink. com.br/colunistas/ColunaDetalhe. aspx?CodColuna =3654. Acessado em: 05 julho. 2010.

[78] HERNANDES, R.; CAZETTA, J. O. Método simples e acessível para determinar amônia liberada pela cama aviária. Revista Brasileira de Zootecnia, v. 30, p. $824-829,2001$.

[79] LEGGETT, J. A.; LANYON, L. E.; GRAVES, R. E. Biological Manipulation of Manure: Getting What You Want from Animal Manure. College of Agricultural Sciences, U.S. Department of Agriculture, and Pennsylvania Counties Cooperating.

[80] FEDER, V. Purificação e Caracterização de uma urease de Cryptococcus gattii. 2010. Dissertação (Mestrado) - Universidade Federal do Rio Grande do Sul, Porto Alegre.

[81] REECE, F. N.; LOTT, B. D.; BATES, B. J. The performance of a computerized system for control of broiler-house environment. Poultry Science, v. 64, p. 261-265, 1985. apud LIU, Z.; WANG, L.; BEASLEY, D. B. A review of emission models of ammonia released from broiler houses. American Society of Agricultural and Biological Engineers ASABE, Paper No 064101, Portland, p. 1-17, 2006.

[82] MEDEIROS, R.; SANTOS, B. J. M.; FREITAS, M.; SILVA, O. A.; ALVES, F. F.; FERREIRA, E. A adição de diferentes produtos químicos e o efeito da 
umidade na volatilização de amônia em cama de frango. Ciência Rural, Santa Maria, v. 38, n. 8, p. 2321-2326, 2008.

[83] OliveIRA, M. C.; FERREIRA, H. A.; CANCHERINI, L. C. Efeito de condicionadores químicos sobre a qualidade da cama de frango. Arquivo Brasileiro de Medicina Veterinária e Zootecnia, v. 56, n. 4, p. 536-541, 2004.

[84] BREWER, S. K.; COSTELLO, T. A. In situ measurement of ammonia volatilization from broiler litter using an enclosed air chamber. American Society of Agricultural and Biological Engineers ASABE, v. 42, n. 5, p. 1415-1422, 1999. apud LIU, Z.; WANG, L.; BEASLEY, D. B. A review of emission models of ammonia released from broiler houses. ASABE, Paper No 064101, Portland, $p$. 1-17, 2006.

[85] INSTITUTO BRASILEIRO DE PETRÓLEO. Manual de Amônia. Rio de Janeiro, 1977.

[86] WRENN, C. Real time measurement of ammonia gas. Occupational Health \& Safety. v. 69, p. 64-67, 2000.

[87] UBA - UNIÃO BRASILEIRA DE AVICULTURA. Protocolo de boas Práticas de Produção de Frango. São Paulo, 2008.

[88] MILES, D. M.; BRANTON, S. L.; LOTT, B. D. Atmospheric Ammonia is Detrimental to the Performance of Modern Commercial Broilers. Poultry Science, v. 83, p. 1650-1654, 2004.

[89] KRISTENSEN , H. H.; BURGES, L. R.; DEMMERS, T. G. H.; WHATES, C. M. The preference of laying hens for different concentrations of atmospheric ammonia. Applied animal behaviour science. v. 68, p. 307-318, 2000.

[90] PAVAN, A. C.; MÓRI, C.; GARCIA, E. A.; SCHERER, M. R.; PIZZOLANTE, C. C. Níveis de Proteína Bruta e de Aminoácidos Sulfurados Totais sobre o Desempenho, a Qualidade dos Ovos e a Excreção de Nitrogênio de Poedeiras de Ovos Marrons. Revista Brasileira de Zootecnia, v. 34, n. 2, p. 568574, 2005. 
[91] LUCAS JUNIOR, J.; SANTOS, T. M. B. Aproveitamento de resíduos da indústria avícola para produção de biogás. In: Simpósio sobre Resíduos da Produção Avícola. Santa Catarina, 2000.

[92] CATARINO, R. P.; GONZÁLEZ, A. P. N.; OLIVEIRA, L. R. P. Otimização da produção de metano na biodigestão da cama de frango. In: I Simpósio Internacional sobre Gerenciamento de Resíduos de Animais e Geração de Energia a partir de Resíduos Animais. Santa Catarina, 2009.

[93] ASTM E 871-82. Standard method for moisture analysis of particulate wood fuels, 1998.

[94] USEPA - UNITED STATES ENVIRONMENTAL PROTECTION AGENCY. Ammonia.

Disponível

em:

http: //www.epa.gov/agriculture/ag101/impactammonia.html. Acesso em: 26 Junho 2010.

[95] WILNDHOLZ, M (ed.). The Merck index. Rahway: Merck\& CO., Inc. 20 ed., p. 498.1938.

[96] PAN, W. P.; WU, A.; RILEY, J. T. Establishment of an Environmental Control Technology Laboratory with a Circulating Fluidized-Bed Combustion System. Quarterly Technical Progress Report. Institute for Combustion Science and Environmental Technology, Western Kentucky University, 2004.

[97] NIST - INSTITUTO NACIONAL DE PADRÕES E TECNOLOGIA. Disponível em: http://webbook. nist.gov/chemistry/cas-ser.html. Acesso em: 29 de setembro de 2010.

[98] HILDITCH, T. P. The chemical constitution of natural fats. New York: John Wiley and Sons, 1941. apud CENTENARO, G. S.; FURLAN, V. J. M.; SOUZASOARES, L. A. Gordura de frango: alternativas tecnológicas e nutricionais. Semina: Ciências Agrárias, Londrina, v. 29, n. 3, p. 619-630, 2008.

[99] BONGAERTS, G. P. A.; UITZETTER, J.; BROUNS, R.; VOGELS, G. D. Uricase of Bacillus fastidiosus properties and regulation of synthesis. Biochimica et Biophysica Acta, v. 527, p. 348-358, 1978. apud KIM, W. K.; PATTERSON, P. H. Effect of minerals on activity of microbial uricase to reduce 
ammonia volatilization in poultry manure. Poultry Science Association, v. 82, p. 223-231, 2003.

[100] MACHIDA, Y.; NAKANISHI, T., Purification and properties of uricase from Enterobacter cloacae. Agricultural and Biological Chemistry, v. 44, p. 28112815, 1980. apud KIM, W. K.; PATTERSON, P. H. Effect of minerals on activity of microbial uricase to reduce ammonia volatilization in poultry manure. Poultry Science Association, v. 82, p. 223-231, 2003. 